\title{
EL IMPACTO DE LA VIOLENCIA ANTICLERICAL EN LA PRIMAVERA DE 1936 Y LA RESPUESTA DE LAS AUTORIDADES
}

\author{
POR \\ Manuel Álvarez Tardío y Roberto Villa García \\ Profesores Titulares de Historia del Pensamiento y los Movimientos Sociales y Políticos \\ en la Universidad Rey Juan Carlos de Madrid
}

\section{RESUMEN}

Este artículo analiza el alcance y las características de la violencia anticlerical en los meses de febrero a junio de 1936. Se han rastreado diferentes fuentes primarias para realizar una estadística lo más precisa y completa posible de esa violencia. Primero, se analiza el contexto en el que ésta tuvo lugar. Segundo, se presentan los datos resultantes de la investigación cuantitativa y cualitativa de la violencia anticlerical. Y tercero, se plantea cuál fue la respuesta de las diversas autoridades ante ese fenómeno. El artículo prueba que los datos sobre violencia anticlerical que se han manejado hasta ahora eran fragmentarios y no contemplaban la magnitud ni el carácter general que llegó a alcanzar en los meses inmediatamente anteriores a la Guerra Civil. Además, demuestra que la reacción del gobierno fue, como poco, ambivalente, no correspondiéndose con las promesas de salvaguardar la legalidad que formuló en privado a la Nunciatura. En muchos casos la violencia anticlerical se produjo ante la pasividad de la policía y/o con la complicidad de las autoridades locales o algunos grupos afines a la coalición que sostenía parlamentariamente al gobierno central.

Palabras ClaVes: Anticlericalismo, Violencia Política, España, Siglo xx, Segunda República.

\section{THE IMPACT OF ANTICLERICAL VIOLENCE IN THE SPRING OF 1936 AND THE AUTHORITIES' RESPONSE}

\author{
AbSTRACT \\ This paper examines the scope and characteristics of anticlerical violence bet- \\ ween February and June 1936. Different primary sources have been used to reach
}


an accurate and complete data as possible of such violence. First, we analyze the context in which this took place. Second, we present the data resulting from quantitative and qualitative research of anticlerical violence. And third, we discuss about the response to this phenomenon of various authorities. The article provides evidence that the anticlerical violence data that have been handled so far were fragmentary and did not provide the magnitude and general character which reached in the months immediately preceding the Civil War. It also shows that the government's reaction was ambivalent. That attitude did not correspond with the promises the government made to the Nuncio in order to safeguard the legality. In many cases anti-clerical violence was the result of police passivity and it had the complicity of local authorities or groups related to the coalition that supported the government in the Congress.

KEY WORDS: Anticlericalism, Political Violence, Spain, 20th Century, Second Republic.

Recibido/Received 22-04-2012

Aceptado/Accepted 13-03-2013

El 14 de abril de 1936 se cumplían cinco años de la proclamación de la Segunda República. Era, por tanto, un día de celebraciones, en el que diversas autoridades iban a compartir una misma tribuna en los actos públicos de conmemoración. En Tarragona, el obispo auxiliar Manuel Borrás asistió, tal y como estaba previsto, al desfile militar. Quizás estaba preparado para escuchar algunas manifestaciones de protesta contra su persona; pero lo ocurrido fue algo más allá de un previsible intercambio de gritos. El obispo fue «duramente abucheado e insultado». Desde algunos lugares le gritaron: « ${ }_{i}$ Fuera, fuera! Esto es una República laica». Finalmente, puesto que la situación podía entrañar cierto peligro para su persona, un grupo de jóvenes católicos lo condujeron escoltado hasta su residencia. ${ }^{1}$

Podía haberse tratado de un incidente aislado, incluso cabría pensar que ciertas protestas, como los gritos, formaban parte de una razonable manifestación de la libertad de expresión en un contexto de indiscutible polarización ideológica en torno a las relaciones Iglesia-Estado y, más concretamente, a la presencia pública de los ministros de la Iglesia católica. Pero ese episodio consistió en algo más que un ejercicio grosero de la libertad de expresión. Borrás experimentó lo que otros muchos religiosos, curas y regulares estaban viviendo desde varias semanas atrás, esto es, una fuerte presión por parte de ciertos grupos extremos para que cambiaran su residencia, se marcharan de sus parroquias o cumplieran

${ }^{1}$ Batllori, M. 1985. «En torno a las relaciones Iglesia-Estado en España durante un periodo conflictivo: febrero-julio de 1936», en C. Moya Espí, L. Rodríguez de Zúñiga y C. Iglesias. Homenaje a José Antonio Maravall, Vol. I: 269. Madrid: CIS..

Hispania Sacra, LXV

132, julio-diciembre 2013, 683-764, ISSN: 0018-215X, doi: 10.3989/hs.2013.033 
con ciertas exigencias que les cursaban las nuevas autoridades locales en temas como la ocupación de las casas rectorales, el toque de campanas, los cementerios o los horarios de misa. En aquellos días, desde que el 16 de febrero se habían cerrado las urnas y se había producido el cambio en el gobierno del país, la Iglesia católica se había convertido en uno de los objetivos recurrentes de una oleada de violencia cuyas características y magnitudes todavía no son bien conocidas. Como si algunos de los eslóganes electorales de la campaña de las izquierdas obreras fueran consignas de obligado cumplimiento, a partir del 17 de febrero, en algunas localidades, ciertos individuos empezaron a actuar conforme al dictado de: «¡Abajo el fascismo vaticanista inquisitorial!», lo que se tradujo en un amplio elenco de protestas, coacciones y hasta actos de violencia física contra las personas y las propiedades de la Iglesia. En su momento se difundieron algunas cifras sobre esa violencia y se hicieron denuncias públicas que, pese a la censura de la prensa, llegaron a la opinión gracias a los debates parlamentarios y las noticias publicadas en los boletines eclesiásticos. Pero no hay duda de que la verdadera dimensión de esos hechos pasó desapercibida para una parte de la opinión pública. No así para el gobierno, que no dejó de recibir, aparte de la copiosa información que le llegaba por vía de los gobernadores civiles, las protestas de las autoridades eclesiásticas. ${ }^{2}$

Hay estudios que aportan información fragmentaria sobre esa violencia anticlerical, pero todavía seguimos sin una estadística completa y fiable de aquellos hechos, al menos en la medida en que la documentación disponible lo permite. Tampoco sabemos lo suficiente sobre la reacción de las autoridades eclesiásticas y la respuesta que obtuvieron sus comunicaciones con el gobierno, todo eso en un difícil contexto en el que algunas autoridades locales y provinciales estaban actuando por su propia cuenta y riesgo y en el que algunos grupos radicalizados pudieron obrar con cierta impunidad. El objetivo de este artículo es doble. Por una parte, presentar una estadística lo más detallada posible de las diferentes manifestaciones que tuvo la violencia anticlerical en los meses de febrero a junio de 1936. Para eso se ha investigado pormenorizadamente la valiosa información del ministerio de la Gobernación de la época, la copiosa documentación parlamentaria y el material inexplorado de los archivos eclesiásticos. Y por otra, relatar las características, hasta ahora poco o nada conocidas, de esa violencia,

2 El cardenal Gomá, visitó a Azaña a finales de marzo. Como hizo público el Boletín del Arzobispado de Toledo, el Primado había manifestado su protesta por los agravios y atropellos cometidos contra la Iglesia, mientras que Azaña le había asegurado que «los derechos reconocidos por las leyes a la Iglesia serían debidamente respetados». Ibídem: 268. En las semanas siguientes, diversas autoridades eclesiásticas, empezando por el máximo representante del Vaticano en España, el nuncio Tedeschini, mantuvieron una interesante correspondencia con diferentes ministros, una correspondencia que será objeto de análisis en este artículo. 
así como las respuestas dadas por las autoridades civiles en los diferentes contextos y momentos.

I. La cuestión religiosa durante la Segunda República ha sido estudiada en profundidad. Ese tratamiento es merecido porque los constituyentes republicanos decidieron, en 1931, asimilar las nuevas reglas del juego republicanas con un amplio programa legislativo que implicaba no solamente una separación de la Iglesia y el Estado sino una política de secularización de las conciencias de orden revolucionario que despertó tanto entusiasmo en las izquierdas republicanas y obreras como rechazo entre los conservadores y los católicos. El desarrollo de esa legislación tuvo amplias consecuencias en campos como la educación, la vida de las órdenes religiosas o la práctica del culto. De este modo, la cuestión religiosa nunca dejó de estar en el debate político de la España republicana, bien fuera para exigir que el Estado actuara en consecuencia con el laicismo constitucional, o bien para defender los derechos de los católicos y de su Iglesia, y levantar una bandera a favor de la revisión de la Constitución. En ese sentido, la postura que unos y otros adoptaron frente al problema de las relaciones Iglesia-Estado y la libertad de conciencia, resultó decisiva para medir su grado de compromiso real con una sociedad democrática y pluralista. Esto es, la cuestión religiosa mostró, como muy pocos aspectos, la complejidad que entrañaba en la España de los años treinta consolidar una democracia que amparara el pluralismo ideológico y la libertad de pensamiento con todas sus consecuencias. ${ }^{3}$ Así, el desarrollo de algunas políticas destinadas a socavar la presencia social, cultural y educativa de la Iglesia se convirtieron en objeto de agrios debates y enfrentamientos sociales y partidistas. Y estos enfrentamientos, en la medida en que polarizaron al electorado en bandos radicalmente enfrentados, no facilitaron, desde luego, la consolidación de un consenso constitucional, convirtiendo cada una de las elecciones en batallas rodeadas de un simbolismo apocalíptico.

Durante la Segunda República se produjo un enfrentamiento relativamente típico en sociedades en proceso de transición hacia una modernidad de orden democrático y liberal con un alto grado de pluralismo y competencia política. Unos deseaban mantener una relación de privilegio de su Iglesia, la católica, con el Estado, puesto que esperaban del segundo que contribuyera, mediante la educación y diferentes prácticas culturales y sociales, a fortalecer una sociedad cohesionada por los principios y valores católicos. Algunos estaban dispuestos a realizar ciertas concesiones, pero admitir con todas sus consecuencias la libertad de conciencia no les resultaba sencillo, sobre todo si ésta era interpretada en términos de un Estado beligerante a favor del laicismo. Otros confiaban en que la República fuera la oportunidad para eliminar de un plumazo la presencia

\footnotetext{
${ }^{3}$ Álvarez Tardío, M. 2002. Anticlericalismo y libertad de conciencia. Política y religión en la Segunda República española (1931-1936), Madrid: CEPC.
}

Hispania Sacra, LXV

132, julio-diciembre 2013, 683-764, ISSN: 0018-215X, doi: 10.3989/hs.2013.033 
social y cultural de la Iglesia católica, a la que responsabilizaban del secuestro del Estado a favor de intereses particulares y en contra de la modernización y el progreso del país. Era normal, hasta cierto punto, que el enfrentamiento entre ambas visiones, una contraria a la modernidad liberal y el pluralismo de valores, y otra favorable a una idea de Estado no ya aconfesional sino laico y beligerante en el progreso de la secularización, conllevara un duro enfrentamiento. Así había ocurrido en otros países europeos de tradición católica desde finales del siglo XIX, como Francia, Bélgica o Italia, aun cuando la cronología y consecuencias de esos conflictos fueran muy diferentes. Sin embargo, en el caso español de los años treinta las tensiones generadas por este conflicto adquirieron un mayor protagonismo desde el momento en que los fundadores de la República consideraron que ésta sólo podía existir y ser tal si contenía entre sus rasgos constitucionales básicos un programa de secularización contundente, es decir, que no pudiera ser objeto de modificación alguna por una política transaccional. Para los republicanos de izquierda y los socialistas la Iglesia católica y sus ministros eran responsables, entre otros grupos de poder, del fracaso de la revolución liberal en España. Si la República quería satisfacer las expectativas que había generado, no cabía practicar una política religiosa transigente con los derechos de los católicos. Estos no eran, desde ese punto de vista, derechos sino privilegios que debían ser menoscabados sin miramientos. ${ }^{4}$

Así, desde muy temprano, la política religiosa de los gobiernos del primer bienio provocó conflictos importantes en el ámbito local, relacionados con aspectos como la supresión del crucifijo de las escuelas, la secularización de los cementerios, los enterramientos católicos, la celebración de algunas prácticas de culto, la disolución de la Compañía de Jesús, o más a medio plazo la sustitución de la enseñanza católica. Las derechas no republicanas aprovecharon esta circunstancia y alzaron la bandera de la revisión constitucional y la defensa de la Iglesia y los católicos..$^{5}$ Además, y esto resultó más impactante y efectivo para la movilización conservadora, se sucedieron importantes episodios de violencia

\footnotetext{
${ }^{4}$ Planteamiento general, en Álvarez Tardío, M. 2005. El camino a la democracia en España, 1931 y 1978. Madrid: Ediciones Gota a Gota: 2005. Análisis de los postulados iniciales sobre la «revolución republicana», en Álvarez Tardío, M. y Villa García, R. 2010. El precio de la exclusión. La política durante la Segunda República, Madrid: 2010. Cap. 1. Europa, especialmente el caso belga, en Conway, M. y Buchanan, T. 1996. Political catholicism in Europe, 1918-1965.: 187-218. Oxford University Press, USA

${ }^{5}$ Verdoy, A. 1995. Los bienes de los jesuitas. Disolución e incautación de la Compañía de Jesús durante la Segunda República, Madrid: Trotta. Álvarez Tardío, M. y Villa García, R. 2010. El precio de la...: 166-179. Álvarez Tardío, M. 2009. «La revolución de las conciencias. Política y secularización en el primer bienio, 1931-1933», en F. Montero García y J. Cueva Merino (eds.), Laicismo y catolicismo. El conflicto político-religioso en la Segunda República. Universidad de Alcalá de Henares: 47-73. Ostolaza, M. 2009. «La guerra escolar y la movilización de los católicos en la II República», en en Ibídem: 326-341. Y Rey Reguillo, F. 2009. «Anticlericalismo, movilización católica e intransigencia política en La Mancha (1931-1936)», en Ibídem: 434-435.
} 
anticlerical que, a ojos de los católicos, eran el corolario lógico del laicismo republicano y socialista, y suponían una auténtica amenaza para su supervivencia. El más dramático de esos episodios durante el primer bienio fue la quema de conventos de mayo de 1931, aunque hubo también otros actos de violencia anticlerical durante las insurrecciones anarquistas, sobre todo la de diciembre de $1933^{6}$ o, por ejemplo, tras el fracaso de la sanjurjada en agosto de 1932. Con todo, el hito decisivo en la explosión de violencia física contra las propiedades de la Iglesia y los religiosos ocurrió con motivo de la Revolución de Octubre de 1934. Para la identidad de los católicos el shock resultó decisivo. La principal prensa conservadora relató pormenorizadamente durante los meses de octubre y noviembre de ese año la dimensión trágica de lo sucedido. Ardieron edificios religiosos y patrimonio de incalculable valor artístico y cultural, aunque la diferencia con actos de anticlericalismo previos vino de la mano de una violencia física contra curas y religiosos que costó la vida a no menos de 34 personas. Resultó significativo de patrones posteriores de violencia anticlerical, que los ataques contra religiosos sucedieron en muchos casos en un contexto de caza y captura del derechista y de identificación de lo católico con el enemigo ideológico conservador. El grupo de mineros que asaltó las Escuelas Cristianas de Turón y condujo detenidos a varios religiosos a la Casa del Pueblo, lo hizo al grito elocuente de: «¡Dónde están las armas de los fascistas de Acción Católica!». Y la consigna de: «iLlevamos fascistas, llevamos curas!», se escuchó cuando se trasladaba a Mieres a un grupo de seminaristas detenidos en Oviedo.?

Los sucesos trágicos de Octubre de 1934 fueron capitales para la movilización conservadora en las elecciones de febrero de 1936. Así como las izquierdas se aglutinaron ante el postulado de la amnistía y la denuncia de la represión, la percepción conservadora sobre lo que había en juego estuvo fuertemente determinada por el recuerdo de Octubre y la violencia anticlerical. Sus principales diarios se encargaron de recordar que, como había quedado establecido desde el principio, «los socialistas» habían «ensangrentado y arruinado la región asturiana» a base de «asesinatos, saqueos y otros crímenes». ${ }^{8}$ Para ellos, de la victoria del bloque popular que formaban socialistas y republicanos de izquierda, pero que también había incluido a los extremos comunista y sindicalista, sólo cabía esperar una política antirreligiosa y humillante por cuanto implicaba la liberación de los culpables del Octubre sacrílego.

${ }^{6}$ Villa García, R. 2011. «La CNT contra la República: la insurrección revolucionaria de diciembre de 1933». Historia y Política 25: 177-205.

7 Montero Moreno, A. 1998. Historia de la persecución religiosa en España: 1936-1939: 46, Madrid: Biblioteca de Autores Cristianos; A. C. N. P. de Oviedo. 1935. Asturias roja. Sacerdotes y religiosos perseguidos y martirizados, Oviedo: 60 .

${ }^{8}$ Palabras de un titular de portada de $A B C, 23-\mathrm{X}-1934$.

Hispania Sacra, LXV

132, julio-diciembre 2013, 683-764, ISSN: 0018-215X, doi: 10.3989/hs.2013.033 
Durante la campaña electoral la cuestión anticlerical no destacó en el discurso de los principales oradores de la izquierda republicana, más allá de reseñar la necesidad de recuperar la política educativa del primer bienio. Sin embargo, en los socialistas y los comunistas sí tuvo una impronta significativa, como si estos estuvieran convencidos de que había una línea de continuidad natural entre la defensa de sus postulados anticlericales y el ejercicio de la violencia. La Iglesia, para ellos, era la otra cara de las clases represoras y de lo que veían como el fascismo cedista; una «iglesia beligerante» a la que atribuían intereses puramente políticos y un afán de poder que no se detenía ante nada, ni siquiera ante el uso de la violencia: «Si en sus manos estuviera, desde los campanarios dispararían los frailazos contra los que osan soñar con una vida civil plena, libre y alegre..» Durante la campaña los socialistas alimentaron recurrentemente la imagen de una Iglesia aliada con la derecha y cuyo triunfo representaría la vuelta de la Inquisición, como rezaba una ilustrativa viñeta publicada a toda página el día 8 de febrero en El Socialista, en la que además podía verse a los curas hermanados con el «capital» y el «fascismo» y a un Vaticano «cruel, egoísta y tirano». Frente a la «voz partidista» del Primado Gomá, los socialistas enarbolaron un lenguaje belicista, en el que el debate se convertía en actos de «disparar» y se advertía a la Iglesia que ellos no se dejaban engañar por las palabras de paz del cardenal. Desde su punto de vista, bastaba con mirar a Octubre para darse cuenta de que la Iglesia sí apoyaba la violencia: «La guerra civil a la que ayer aludíamos viene a convertirse ahora, merced al aislamiento prelaticio, en una guerra santa. La guerra al infiel... salvo cuando se trata de dominar insurrectos en Asturias. Poco importa que el prelado aconseje paternalmente a los fieles y les recomiende que renuncien a toda violencia. Es una recomendación que se formula a sabiendas de que no han de hacerle caso.» ${ }^{10}$ Para los socialistas, en definitiva, la iglesia era «un partido político más» que los banqueros, los usureros y los terratenientes, entre otros poderosos, utilizaban para comprar conciencias y ganar dinero. «En las próximas elecciones desatarán los clérigos una terrible ofensiva contra la democracia republicana» y el maestro de orquesta será Gil Robles. ${ }^{11}$

Dos aspectos destacan, a efectos de este artículo, del discurso de las izquierdas obreras del Frente Popular antes del 16 de febrero. De un lado el lenguaje violento utilizado para criticar la asociación entre catolicismo y cedismo, como si los católicos y su Iglesia estuvieran cometiendo un delito de antirrepublicanismo por el hecho de hacer política y defender unas u otras candidaturas en las elecciones. Y de otro, si cabe más importante, la ausencia consciente de cualquier atisbo de autocrítica con relación a la revolución de Octubre. Al contrario, ésta se consideraba una acción defensiva contra el

\footnotetext{
${ }^{9}$ Editorial «Una iglesia beligerante», El Socialista, 4-II-1936.

${ }^{10}$ El Socialista, 31-III-1936.

${ }^{11}$ El Socialista, 4-II-1936.
} 
ascenso del fascismo que tendría ahora continuidad plena en las elecciones, una misión para la que resultaba crucial frenar a los católicos. En el lenguaje socialista no había ninguna mención de la Iglesia o los religiosos como víctimas de la violencia de Octubre, sino solamente como copartícipes de «la reacción» y socios del fascismo. De forma indirecta, por tanto, El Socialista daba un paso más allá de la crítica a la Iglesia, esto es, justificaba la violencia anticlerical cometida por los revolucionarios en Octubre en tanto que violencia preventiva y en defensa de la democracia.

Sería muy sencillo colegir de esta retórica violenta del discurso socialista antes de las elecciones la idea de que los actos violentos contra iglesias y religiosos perpetrados a partir del 17 de febrero y durante los meses siguientes eran parte de un guión previamente establecido. Es incuestionable el hecho de que la campaña electoral de las izquierdas obreras, especialmente de sus sectores más radicalizados, apeló a la idea de las elecciones como segundo episodio de lo ocurrido en Octubre y que, por tanto, de forma implícita se estaba justificando cierta violencia que, después de celebradas, se disculparía como actos de justicia popular por los meses previos de represión. Como afirmaría Rodolfo Llopis en las Cortes el 15 de abril: «la Iglesia, imprudentemente, a nuestra manera de ver, tomó partido, jugó y ha perdido. Por lo tanto, tenía que sufrir las consecuencias de su pérdida». El diputado socialista, además, justificó los incendios y asaltos de iglesias ocurridas porque en todas ellas «se ha[bía]n encontrado los documentos o, por lo menos, las papeletas electorales que acredita[ba]n la parte que ha[bía]n tomado en las últimas elecciones». Significativamente, sólo lamentó la quema de iglesias y conventos en la medida en que los edificios destruidos no podrían ser utilizados para otros fines. ${ }^{12}$

Sin embargo, que finalmente la amenaza verbal se convirtiera en actos violentos concretos dependía de otros factores, como la determinación de las nuevas autoridades republicanas en el control del orden público o el extremismo de algunos grupos de izquierdas en el ámbito local. Es evidente que no bastaba con usar un lenguaje radical y excluyente para que los militantes de las izquierdas obreras se lanzaran a la calle a quemar iglesias o asaltar centros de Acción Católica. Pero sin duda esa beligerancia anticlerical sobre el papel facilitaba la interpretación rigurosa de la victoria electoral, a modo de una oportunidad de venganza que algunos no desaprovecharon.

El hecho cierto es que muy pocos días después de que se cerraran los colegios electorales se sucedieron actos de violencia anticlerical en diferentes localidades del país. La censura ejercida sobre la prensa, especialmente la nacional, impidió un relato pormenorizado de esa violencia, aunque algunos datos fueron

${ }^{12}$ Diario de Sesiones de las Cortes (DSC), 15-IV-1936: 308.

Hispania Sacra, LXV

132, julio-diciembre 2013, 683-764, ISSN: 0018-215X, doi: 10.3989/hs.2013.033 
expuestos en aquellos meses por varias intervenciones parlamentarias. La primera fue la del líder de la derecha monárquica, Calvo Sotelo. El día 15 de abril, en el debate de presentación del gobierno Azaña, aseguró que desde el 16 de febrero hasta el 2 de abril se habían producido 106 incendios en iglesias y 36 asaltos y destrozos en templos. Casi un mes más tarde, de nuevo en las Cortes, completó esos datos al referirse a lo ocurrido entre el 1 de abril y el 4 de mayo, período para el que había computado hasta 52 incendios, en su mayor parte de iglesias. ${ }^{13}$ El cedista Gil Robles contaba también con datos precisos, procedentes, a buen seguro, de la información censurada por Gobernación a El Debate pero que él podía conocer perfectamente de manos del director del rotativo, Francisco de Luis. En un importante debate que tuvo lugar en las Cortes el 16 de junio, fruto de una proposición no de ley en la que se pedía «la rápida adopción de las medidas necesarias para poner fin al estado de subversión en que vive España», el líder cedista afirmó que en el período de 16 de febrero a 15 de junio habían sido destruidas totalmente 160 iglesias (una cifra, por lo tanto, semejante a la señalada por Calvo Sotelo, que ascendía a 158) y se habían producido 251 asaltos de templos, incendios sofocados, destrozos e intentos de asaltos. Un mes más tarde, en la tormentosa sesión de la Diputación Permanente, recién asesinado Calvo Sotelo, Gil Robles aseguró que en los días transcurridos desde su anterior intervención se habían añadido 10 iglesias más incendiadas. Por lo tanto, según los datos de Gil Robles, el total de iglesias incendiadas desde las elecciones hasta mediados de julio ascendía a $170 .{ }^{14}$

¿Se acercaban a la verdad las estadísticas expuestas por los dirigentes de las derechas o por el contrario se trataba de datos inflados para despertar el pánico conservador y preparar el terreno para un golpe de estado? ¿Hasta qué punto la radicalización de las izquierdas condujo a una política práctica de acoso y derribo de los católicos y de su Iglesia? ¿Se cumplieron los peores pronósticos sobre las consecuencias negativas para los católicos que tendría el cambio de algunas autoridades locales?.

Algunos estudios se han referido a la violencia anticlerical en la primavera de 1936. Parece evidente que en el «colapso del orden público» que se produjo con el gobierno republicano de izquierda de 1936 hubo muchos tipos de violencias entre las que se encuentran los incendios provocados y otros actos de tipo anticlerical..$^{15}$ En un artículo pionero publicado en 1978, basado en fuentes sorprendentemente exiguas, Cibrián aportaba las siguientes categorías y datos:

${ }^{13}$ DSC, 15-IV-1936: 290; у 6-V-1936: 621.

14 DSC, 16-VI-1936: 1374-1375. Diario de Sesiones de la Diputación Permanente de Cortes, 15-VII-1936: 6.

${ }^{15}$ Entrecomillado, en Payne, S. G. 2005. El colapso de la República: 541. Madrid: Esfera de los Libros. 
35 iglesias o edificios totalmente quemados y 85 con daños parciales, lo que supone un total de 120 entre el 31 de enero y el 17 de julio. ${ }^{16}$ Sin embargo, los datos publicados por historiadores de la iglesia que conocían bien el terreno en el que se movían, dejaban en evidencia los anteriores: en un volumen publicado a finales de los noventa se hablaba de más de 300 templos incendiados entre el 16 de febrero y el 19 de mayo. ${ }^{17}$

No pocos estudios posteriores se han limitado a reproducir, y no siempre bien, las cifras aportadas por Gil Robles en las Cortes. Otros han copiado, sin más, los datos de Cibrián. No obstante, en el ámbito regional se ha avanzado y para algunos casos se conocen algo mejor los episodios de violencia anticlerical en aquellos meses, gracias en buena medida al estudio de la prensa regional - menos ahogada por la censura - y a los archivos provinciales y locales. ${ }^{18}$ Así, el libro de González Gullón sobre el clero en Madrid ha supuesto un avance muy notable para la comprensión de la verdadera dimensión de la violencia anticlerical y la quema de edificios religiosos en el Madrid posterior a la victoria del Frente Popular. ${ }^{19}$ Recientemente, el libro de Blázquez Miguel, basado en un copioso estudio de fuentes hemerográficas pero con una metodología imprecisa, aporta los datos siguientes para el período completo de 17 de febrero a 17 de julio: 239 iglesias quemadas y 216 profanadas o asaltadas. ${ }^{20}$ Por su parte, en un interesante estudio sobre la iglesia y el carlismo durante la Segunda República, Moral Roncal recoge los datos publicados no hace mucho por Cárcel Ortí. Según estos, que son resultado de la información procedente de los archivos eclesiásticos, entre el 16 de febrero y el 1 de abril ardieron 69 iglesias, mientras que otras 105 fueron saqueadas o atacadas. ${ }^{21}$ El mismo Cárcel Ortí había publicado ya en

${ }^{16}$ Computaba aparte 23 intentos de incendio de edificios religiosos. Su fuente era básicamente el trabajo de Malefakis, completado con algo de prensa iberoamericana y datos de Ricardo de la Cierva. Cibrián, R. 1978. «Violencia política y crisis democrática: España en 1936». Revista de Estudios Políticos 6: 84 .

17 Andrés-Gallego, J. y Pazos, A. M. 1999. La Iglesia en la España contemporánea. Vol II: 19361999: 18-19. Madrid: Encuentro..

18 Rey Reguillo, F. 2008. Paisanos en lucha. Exclusión política y violencia en la Segunda República española: 534-537. Madrid: Biblioteca Nueva. Macarro, J. M. 2000. Socialismo, República y Revolución en Andalucía (1931-1936): 443. Universidad de Sevilla, 443 y ss. Grandío Seoane, E. 1998. Los orígenes de la derecha gallega: la CEDA en Galicia (1931-1936): 281. La Coruña: Ediciós Do Castro. Ortiz Heras, M. 1996. Violencia política en la II República y el primer franquismo. Albacete, 1936-1950: 56. Madrid: Siglo xxi. Ordóñez Márquez, J. 1968. La apostasía de las masas y la persecución religiosa en la provincia de Huelva 1933-36: 38-43 y 86-98. Madrid: 38-43 y 86-98.

19 González Gullón, J. L. 2011. El clero en la Segunda República. Madrid, 1931-19363: 90-397 Burgos: Monte Carmelo.

${ }^{20}$ Blázquez Miguel, J. 2009. España turbulenta. Alteraciones, violencia y sangre durante la II República: 716-717.Villanueva del Pardillo (Madrid) Tomás P’rez y María Dolores.

${ }^{21}$ Moral Roncal, A. M. 2009. La cuestión religiosa en la Segunda República española. Iglesia y carlismo: 223. Madrid: Biblioteca Nueva. Los datos proceden de Cárcel Ortí, V. 2008. Pío XI entre la República y Franco: 643-660. Madrid: BAC. Se ha publicado también información muy valiosa,

Hispania Sacra, LXV

132, julio-diciembre 2013, 683-764, ISSN: 0018-215X, doi: 10.3989/hs.2013.033 
el año 2000 un trabajo en el que hacía referencia a los datos del ministerio de la Gobernación y de la curias diocesanas, señalando que en los cinco meses de febrero a julio habían ocurrido «varios centenares» de quemas y saqueos de iglesias, unos datos que confirmarían la veracidad de lo expuesto por los obispos en su Carta Colectiva del 1 de julio de 1937, en la que cifraron en 411 las iglesias destruidas o profanadas antes del estallido de la guerra. ${ }^{22}$

Este ir y venir de datos se debe, sin duda, a la ausencia de fuentes que durante mucho tiempo ha impedido elaborar una relación más precisa de la violencia anticlerical, aunque también a que no se ha profundizado en el estudio de informes que, como los del ministerio de la Gobernación o los archivos diocesanos, están disponibles desde hace tiempo. Por otro lado, mientras un estudio riguroso no afirmara o negara los datos aportados por los diputados conservadores, siempre cabía la posibilidad de señalar que esas cifras estaban infladas y que su único propósito era, sin más, propagar el miedo entre la ciudadanía conservadora y justificar una acción posterior de fuerza. ${ }^{23}$ No en vano, si es sabido desde hace tiempo - puesto que esa documentación está en el Archivo del Ministerio de Asuntos Exteriores y ha sido parcialmente publicada- que Azaña, ante la protesta formal de la Nunciatura a mediados del mes de marzo, había contestado, no sin cierto sarcasmo, que «no ha[bía] dejado el gobierno ni un solo momento de usar los resortes que están a su alcance para evitar, como lo ha logrado, la extensión de los hechos». Estas palabras, a nadie se le puede ocultar, eran implícitamente un reconocimiento de que los «hechos» denunciados por Tedeschini no eran inventados. Es más, unos días más tarde, el mismo Azaña deploraba los atropellos, volviendo a admitir su existencia, aunque esta vez utilizando la sorprendente maniobra de trasladar la culpabilidad a «predicaciones inoportunas». ${ }^{24}$

Que la primavera de 1936 fue el momento en el que mayor alcance tuvo la violencia anticlerical antes de la guerra es un hecho, por tanto, incuestionable.

procedente de los archivos eclesiásticos, en el estudio sobre el cardenal Gomá de Dionisio, M. A. 2011. Isidro Gomá ante la dictadura y la República: 110-118 Toledo: Instituto Teológico San Ildefonso, 110-118.

22 Cárcel no daba todavía una cifra concreta en ese trabajo. Cárcel Ortí, V. 2000. La gran persecución. España, 1931-1939: 101-101 Barcelona: Planeta.

${ }^{23}$ Este tipo de afirmaciones, basadas en un análisis sesgado y prejuicioso de algunas fuentes, se pueden encontrar, por ejemplo, en González Calleja, E. 2011. Contrarrevolucionarios. Radicalización violenta de las derechas durante la Segunda República, 1931-1936. Madrid: Alianza Editorial, 332334, que habla de «los voceros de la derecha más radical» denunciando «el deterioro constante del orden público» como estrategia para propugnar un Estado autoritario. También en esa misma línea, en Lowe, S. 2010. Catholicism, War and the Foundation of Francoism. The Juventud de Acción Popular in Spain, 1931-1939. Brighton: Sussex Academic Press, 122.

${ }^{24}$ Archivo del Ministerio de Asuntos Exteriores, 892, Exp. 19, notas de 17 y 25 de marzo de 1936. Cit. en García-Prous, C. 1996. Relaciones Iglesia-Estado en la Segunda República Española: 213. Córdoba: Caja Sur. 
Por nuestra parte, hemos rastreado minuciosamente distintas fuentes. De un lado la información que siempre ha estado disponible, tanto de Gobernación como de Justicia. De otro, hemos tenido en cuenta también el Diario de Sesiones de las Cortes y la valiosa documentación enviada desde las curias diocesanas a la Nunciatura de Madrid. Las decenas de cartas elaboradas por los párrocos y los obispos, así como los informes de la Nunciatura han resultado fundamentales para complementar y contrastar los datos de Gobernación.

II. Las fuentes indicadas han permitido la reconstrucción de la serie prácticamente completa de actos violentos de carácter anticlerical entre el 17 de febrero y el 16 de junio de 1936. La prensa también ha sido utilizada en términos de contraste pero su valor para ponderar el impacto real de la violencia anticlerical se vuelve especialmente relativo, merced al efecto creciente de la censura ejercida por el gobierno y sus delegados en provincias. Ésta impidió todo conocimiento de una parte sustancial de los sucesos que sí refieren tanto la documentación de la Nunciatura como del Ministerio de la Gobernación. Gran parte de los actos de violencia anticlerical que sí se publicaron fueron filtrados de tal forma que se obstaculizó el conocimiento de las circunstancias del suceso, la evaluación real de los daños e incluso de la cronología, al ser publicados con varios días de retraso por imposición gubernativa. ${ }^{25}$ De ahí que la prensa apenas haya constituido más que una fuente auxiliar de las eclesiásticas y gubernativas.

Para el periodo entre el 17 de junio y el 17 de julio, las fuentes utilizadas se vuelven parcas o, por lo común, no existen. Que sepamos, no volvió a requerirse a los obispados informes detallados sobre este tipo de actos -quizás porque lo impidió la cercana y abrupta ruptura del orden constitucional. En cuanto al Diario de Sesiones, Martínez Barrio y Jiménez de Asúa, entonces presidente y vicepresidente de las Cortes, comenzaron a limitar a partir de mayo la inserción de enumeraciones de actos violentos porque algunos diputados de la oposición - básicamente el monárquico Calvo Sotelo y el progresista Fernández Castillejo - acudían a este procedimiento para que pudieran llegar a la opinión pública a través de la prensa, ya que las intervenciones en Cortes no estaban sujetas a censura. De todas formas, a partir de esa fecha ésta también comenzó a impedir a la prensa la publicación de la documentación parlamentaria.$^{26}$ Los informes de Gobernación escasean también para este último mes. Pero la parquedad de información, que ha impedido una estadística eficiente para ese

${ }^{25}$ De ahí que el único estudio sistemático basado casi exclusivamente en prensa, el ya citado de Blázquez Miguel, se haya encontrado con muchos obstáculos a la hora de precisar numerosos sucesos o conocer muchos otros. Como admite en p. 718, sus cifras sólo pueden considerarse como una aproximación.

${ }^{26}$ DSC, 6-V-1936: 625 y 627; 18-VI-1936: 1458-1459; y 26-VI-1936: 1640-1641. La censura impidió por diez días la publicación de la última serie de actos de violencia que refiere el Diario de Sesiones. Vid. $A B C, 17-\mathrm{V}-1936$.

Hispania Sacra, LXV

132, julio-diciembre 2013, 683-764, ISSN: 0018-215X, doi: 10.3989/hs.2013.033 
periodo, no matiza las cifras que se expondrán a continuación. Las noticias que hemos podido recoger para algunas provincias hasta el 18 de julio, combinadas con las interpelaciones y denuncias de los diputados de la oposición e incluso la prensa, evidencian la continuación de este tipo de actos violentos hasta el mismo comienzo de la guerra. ${ }^{27}$

En cuanto al objeto de análisis, hemos introducido una variación respecto a los estudios anteriores. No nos hemos limitado a contabilizar la cifra de edificios religiosos afectados por incendios o asaltos. Por dos razones. En primer lugar, con ser estos los ataques más visibles y destacados numéricamente, no agotan la violencia habida entre febrero y junio de 1936. Y en segundo lugar, porque este método introduce una distorsión que tiende a minimizar el impacto real de la violencia. En realidad, se ha podido comprobar como el deterioro, incluso la destrucción, de estos edificios y de lo que contenían no fue fruto de un único ataque, sino de varios a lo largo del periodo analizado.

Por ello, este trabajo contabiliza el número de actos violentos cometidos contra personas, edificios, monumentos y objetos de carácter religioso, incluyendo los de asociaciones de seglares directamente vinculadas a la Iglesia y dedicadas a funciones estrictamente confesionales como la Acción Católica. No se incluyen, por el contrario, los practicados contra los partidos o sindicatos con denominación de católicos, cuyas funciones iban bastante más allá de las catequéticas y que no se encuadraban estrictamente en la organización eclesial. Entendemos, además, actos violentos en su acepción más estricta e inequívoca, es decir, situaciones en las que hubo una agresión física manifiesta contra personas o bienes. No se han contemplado los episodios de amenazas y coacciones en las que no medió agresión por ser, en ocasiones, difícilmente interpretables, debido a la inevitable subjetividad de muchos de los relatos insertos en las fuentes consultadas. En parte por esto tampoco se han incluido otros episodios como las huidas o expulsiones de clérigos, las multas, las detenciones y los registros e incautaciones de edificios religiosos impuestas por las autoridades provinciales y locales. No obstante, a pesar de que estos sucesos no derivaron, las más de las veces, en violencia manifiesta y por ello no se han incluido en la estadística, sería demasiado reduccionista no tenerlos en cuenta para un análisis cualitativo. Sobre todo cuando, por ejemplo, la ausencia forzada de curas, monjas y frailes de sus respectivas parroquias y conventos constituía, como expresaban en misivas a sus superiores, evidencias de una situación anormal, en la que no se garantizaba su seguridad personal ni la continuidad de su labor pastoral y

27 Pese a la censura, periódicos como La Vanguardia insertaron noticias de actos de violencia anticlerical en las provincias de Ávila, Guipúzcoa, La Coruña, León, Logroño, Oviedo y Santa Cruz de Tenerife el último mes antes de la guerra. Más evidencias, en AGA Serie 008/44 C. 2791; y DSC, 8-VII-1936: 1979-1981. 
proselitista ${ }^{28}$ Sin olvidar que, cuando las multas, detenciones o expulsiones de personal religioso y la incautación de los bienes de culto eran iniciativa de las autoridades locales, muchas veces se generaban situaciones que contravenían de forma manifiesta la legalidad entonces vigente..$^{29}$

Las fuentes también son parcas a la hora de informar sobre los autores de las agresiones y de su significación política, por lo que no se ha podido establecer una estadística precisa en este aspecto. Sólo se posee algún dato en menos de un $6 \%$ de los casos verificados. Tampoco esto es de extrañar. Buena parte de los actos de violencia anticlerical se cometieron con nocturnidad o en circunstancias que permitían la huida de sus autores. Del mismo modo, hubo pocas detenciones y, como norma general, las que se practicaron por la Guardia Civil y de Asalto fueron breves merced a la intercesión de los alcaldes. Las detenciones más largas las sufrió el propio personal religioso, así como individuos descritos en las fuentes de Gobernación como vecinos que pretendían evitar los ataques, defender los edificios o enfrentarse con los agresores, calificados frecuentemente de «fascistas» 0 «derechistas», aunque los informes de alcaldes y algunos delegados se culpe a los mismos de la violencia. Se conoce mejor la identidad de quienes asaltaban los edificios religiosos y destruían su mobiliario con el fin de convertirlos en centros obreros o casas del pueblo, que son frecuentemente descritos como «socialistas», «Juventud Socialista» o «comunistas». También aparecen referencias a una «Guardia Roja» que se dedicó con preferencia a asaltar y ocupar - en algunos

${ }^{28}$ Archivo Segreto Vaticano (ASV), Nunz. b. 925 y 945. Archivo de la Diócesis de Toledo (ADT), Secretaría $1936, \mathrm{n}^{\circ} 6$.

${ }^{29}$ Durante los estados de alarma, los artículos 40 a 43 de la Ley de Orden Público vigente permitían a la autoridad civil, incluyendo a los alcaldes, ordenar detenciones preventivas, imponer el cambio de domicilio o el destierro forzoso a personas que considerasen «peligrosas» o contra las que existieran «sospechas de participación en actos contra el orden público», así como decretar registros sin mandamiento judicial. Pero como establecía el artículo 8 , los alcaldes debían solicitar instrucciones, antes de actuar, al gobernador civil o, si la situación del orden público imposibilitara esta gestión, habían de dar cuenta a éste «lo más rápidamente posible de sus actos». Como rara vez podía demostrarse la peligrosidad del personal religioso respecto del orden público, algunos alcaldes actuaron por su cuenta y riesgo, sin informar a los gobernadores ni tampoco obedecerles cuando éstos ordenaban la reintegración de esas personas al municipio de residencia, o su puesta en libertad. Eso sí, las fuentes de que disponemos relatan que la mayoría de los alcaldes que deseaban deshacerse del cura o del clero regular en sus pueblos, para no malquistarse con la autoridad provincial, simplemente adoptaban una postura negligente, y justificaban detenciones o simples consejos de abandono del pueblo con el prurito de no poder garantizar su seguridad personal. También les estaba vedado a los alcaldes decidir sobre la clausura de una orden religiosa, por momentánea que fuere, algo que competía sólo al gobierno. Sin embargo, se han constatado numerosos casos en que los alcaldes ordenaron tales clausuras. En cuanto a la incautación de instalaciones de uso eclesiástico, conforme a los artículos 12 y 13 de la Ley de Confesiones y Congregaciones Religiosas, los alcaldes no podían ejercerla por sí, sino por mandato del gobierno, siempre que éste hubiera obtenido la previa autorización de las Cortes mediante una ley especial. Vid. Gaceta de Madrid, 30-VII-1933: 683 y 686; y 3-VI-1933: 1651 y 1653.

Hispania Sacra, LXV

132, julio-diciembre 2013, 683-764, ISSN: 0018-215X, doi: 10.3989/hs.2013.033 
casos, incendiar - colegios religiosos en Madrid o a agredir a algún sacerdote como en Infiesto (Oviedo). Por último, en las cartas de los obispos al Nuncio se refiere que en León y Sevilla algunas iglesias y conventos pasaron a estar en poder de las «sociedades socialistas», y se destaca el papel de los «jóvenes socialistas y comunistas» en las amenazas a sacerdotes y frailes en provincias como Almería, Badajoz, Cáceres, Granada, Guadalajara, Salamanca o Toledo, o en registros de conventos, acompañando a guardias de Asalto, como en Granada, Murcia y Zamora. El papel de los anarquistas aparece reducido a los asaltos de iglesias en Casarabonela (Málaga) y Requejo (Zamora), aunque su intervención pudo ser más destacada en los incendios de edificios religiosos. No existen evidencias que impliquen a militantes republicanos en esta violencia, más allá de las juventudes de ERC, que derribaron tres cruces monumentales en el parque Güell de Barcelona. ${ }^{30}$

Con estas salvedades, acotando a la violencia anticlerical a los actos de agresión manifiesta, la estadística que hemos elaborado arroja un total de 957 actos violentos en los 121 días que median entre el 17 de febrero y el 16 de junio de 1936. Se han diferenciado en cinco categorías que se exponen a continuación.

\section{Tabla I}

\section{ACTOS DE VIOLENCIA ANTICLERICAL PERPETRADOS ENTRE EL 17 DE FEBRERO Y EL 16 DE JUNIO DE 1936}

\begin{tabular}{|c|c|}
\hline Categorías & Número de Actos \\
\hline Edificios religiosos incendiados, parcial o totalmente & 325 \\
\hline Edificios religiosos asaltados y/o saqueados & 416 \\
\hline Otros atentados y conatos de incendio y asalto contra edificios religiosos & 129 \\
\hline Derribo y/o destrucción de otros monumentos religiosos & 56 \\
\hline Agresiones a personal religioso & 31 \\
\hline Total de Actos de Violencia & 957 \\
\hline
\end{tabular}

Datos elaborados a partir de: ASV, Nunz. b. 912, 925, 945 y 967. AHN (Salamanca), P-S Madrid, 152, 1536, 2376-77 y 4550. ADT, Secretaría 1936, nº 6. AHP (Logroño), Gobierno Civil, cit. en Gil Andrés, C. 2000. Echarse a la calle. Amotinados, huelguistas y revolucionarios (La Rioja, 1890-1936). Zaragoza: Prensas Universitarias. DSC, 15, 16 y 18-IV, 5, 6 y 7-V, 4 y 11-VI, y 8-VII-1936. ABC y La Vanguardia, 17-II a 20-VI-1936.

${ }^{30}$ ASV, Nunz. b. 912, 925, 945 y 967. AHN (Salamanca), P-S Madrid, 152, 1536 y 2376-77. Un ejemplo ilustrativo es el escrito recibido por el cura de La Mata (Toledo): «Señor Cura: Le damos veinticuatro horas de prórroga para que abandone este pueblo; y desde luego, si así no lo hace, aténgase a las consecuencias; así es que luego no diga que no le hemos avisado; nada más. Salud, República y Revolución. Dos firmas ilegibles. Sociedad Obrera Socialista.» En ASV, Nunz., b. 925. 
La primera categoría, la que más ha llamado la atención de los historiadores, es la de iglesias, conventos, casas rectorales y sedes de Acción Católica incendiados. En ésta se engloban los edificios religiosos que resultaron gravemente dañados o destruidos a resultas de las llamas, pero también los que sufrieron desperfectos parciales. Su incidencia fue notable, habida cuenta de que representaron más de un tercio de los actos violentos, exactamente un $34,0 \%$. De su carácter destructivo, y también de circunstancias que se dieron de forma repetida como la nocturnidad - que retrasaba una respuesta eficaz por parte de vecindario y autoridades - y también la falta de una intervención adecuada por parte de estas últimas, da cuenta el hecho de que 210 de los 325 ataques analizados tuvieron graves consecuencias para la estructura de los edificios, causándoles fortísimos estragos y, en numerosos casos, destruyendo totalmente los mismos, caso de iglesias y/o conventos de Madrid capital y Buitrago del Lozoya (Madrid); Caranza y Serantes (La Coruña), Ruitelán (León), Niebla (Huelva), Benaoján (Málaga); Béjar (Salamanca); Lardero, Logroño y Villamediana de Iregua (Logroño); Zujaira o Granada capital (Granada). Según los mismos datos del Ministerio de la Gobernación, para el 30 de abril se habían destruido totalmente 98 iglesias. Algunos de estos edificios llegaron a sufrir dos o más ataques incendiarios hasta convertirse en ruina. No obstante, también fue frecuente que la gravedad de los daños se circunscribiera a partes del edificio gracias a la intervención del vecindario, de los bomberos y la fuerza pública. ${ }^{31}$

A pesar de su importancia, quizás la espectacularidad de los incendios de edificios religiosos ha restado importancia a la segunda categoría, la de asaltos que no implicaron quema y desperfectos estructurales. En realidad fue la más abundante, pues representó un $43,5 \%$ del total de actos violentos, y su incidencia para entorpecer las labores de culto e intimidar a los católicos fue tan importante como la anterior. Los asaltos consistían en la irrupción de individuos al margen de la autoridad pública en edificios religiosos, casi siempre fuera del horario de culto, con intenciones diversas. La gran mayoría de las veces, la pretensión tendía a inhabilitar el uso religioso del edificio mediante el saqueo, destrozo o la quema del mobiliario, altares, objetos de culto e imágenes. La interrelación entre el asalto de un espacio religioso y estas actividades es tan estrecha que las pocas veces en que un asalto no terminó en destrucción del mobiliario fue porque sus autores resultaron descubiertos por los sacerdotes y la fuerza pública antes de que pudieran emprender estas tareas. Fue lo que ocurrió, por ejemplo, en Puerto de Santa María (Cádiz), Cuenca, Gerona o La Laguna (Santa Cruz de Tenerife). En algún caso, como Benifairó de Valldigna (Valencia) o Ribavellosa

\footnotetext{
${ }^{31}$ Para evitar la reiteración de las notas, remitimos a las fuentes de la Tabla I, de donde proceden los ejemplos con que ilustramos las diversas categorías en esta y las siguientes páginas.
}

Hispania Sacra, LXV

132, julio-diciembre 2013, 683-764, ISSN: 0018-215X, doi: 10.3989/hs.2013.033 
(Álava), personas calificadas como «vecinos» no esperaron la llegada de la fuerza pública e intervinieron, utilizando incluso sus armas de fuego para hacer huir a los asaltantes. Sólo en casos muy limitados estos últimos se contentaron con variar de sitio las imágenes, como en Alburquerque (Badajoz), o en realizar pintadas insultantes, caso de Tolilla (Zamora).

El hecho de que los asaltantes respetaran la estructura del edificio limitándose a destrozar el contenido, no era casual. En un número apreciable de localidades se ha apreciado cómo existían presiones y amenazas por parte de afiliados a los grupos de la izquierda obrera, y en algunos casos hasta de las nuevas autoridades municipales, para que los sacerdotes abandonaran las casas rectorales o entregaran las llaves de iglesias y ermitas con el fin de darles un uso distinto. Lo mismo ocurrió con algunos colegios regentados por religiosos, que fueron asaltados, clausurados y en numerosos casos incluso incendiados, sobre todo en Madrid y municipios de su provincia (Aranjuez, Canillas, Carabanchel Bajo, Ciempozuelos, Mejorada del Campo o Vicálvaro).

Si tales presiones venían directamente de los partidos o sociedades obreras, hecho que se ha podido constatar repetidas veces para esta circunstancia concreta y sobre todo en el transcurso de las celebraciones del $1^{\circ}$ de Mayo - aunque también en otras fechas a lo largo del periodo estudiado-, la finalidad fundamental era convertir esos edificios en sus propios centros políticos. El hecho de que los curas se resistieran a las coacciones, notoriamente ilegales, precipitaba los asaltos tumultuarios de los edificios religiosos, su toma en posesión izando de forma simbólica la bandera roja, y su rápida desacralización mediante el saqueo, destrozo y/o quema de mobiliario, imágenes y objetos de culto. En este caso el asalto suponía ocupación permanente, por lo menos hasta que la llegada de la fuerza pública desalojaba a los asaltantes, aunque hemos constatado 39 casos en los que las autoridades sancionaron tácitamente la ocupación. ${ }^{32}$

Pero hubo casos significativos en que los asaltos no tendían a salvaguardar el edificio destruyendo el mobiliario, sino que a veces constituían el prolegómeno o el episodio frustrado de su mismo incendio y destrucción

${ }^{32}$ Son los de Los Cortijos (Ciudad Real); Barajas de Melo, Cardenete, Iniesta y Valdemoro Sierra (Cuenca); Albuñol, Castell de Ferro, Chimeneas, Domingo Pérez, Dúrcal, Gobernador, Guájar Faragüit, Los Villares y Quéntar (Granada); El Ferrol, La Coruña, Santiago de Compostela y Vilaboa (La Coruña); Archidona (Málaga); los seis núcleos del concejo de Caso (Oviedo); Almensilla, El Viso del Alcor, Marchena, Peñaflor y San Juan de Aznalfarache (Sevilla); Burguillos, Navahermosa, Nombela, Urda y Villacañas (Toledo); Beniopa, Jeresa y Villanueva de Castellón (Valencia). En Sarratella (Castellón), el alcalde no sólo permitió la celebración de un baile en la iglesia sino que expulsó al párroco de la localidad. 
desde dentro. Este hecho hace que no debamos tomar las categorías enunciadas como compartimentos estancos, sin relación entre unas y otras. Algunos episodios se cuentan como asaltos y no como incendios sólo debido a la interposición de la fuerza pública, pero no a la intencionalidad de los autores. Así, la llegada de la Guardia de Asalto evitó que se prendiera fuego a la iglesia y a la casa rectoral de Catarroja (Valencia), después de haber sido asaltadas y saqueadas. La Guardia Civil hizo lo propio en los sucesos de marzo en la barriada del Puente de Vallecas, en Madrid, además de en Rota (Cádiz), Alomartes y Lanjarón (Granada), Baeza (Jaén), Chamorro y Filgueira (La Coruña), Álora y Vélez Málaga (Málaga), Moratalla (Murcia), Écija (Sevilla) y Carlet (Valencia).

En esta categoría también se han incluido los asaltos que degeneraron en robos de objetos de culto. Si bien en otros contextos estas actividades podrían desvincularse de la violencia anticlerical y ser interpretadas como delincuencia común, no es posible hacerlo para el periodo que estudiamos. Los latrocinios rara vez aparecieron de forma aislada, sino que ocurrían a la vez en situaciones donde se destrozaban o quemaban imágenes y enseres. En realidad, el valor de algunos objetos de culto, sobre todo los cálices y copones, y la existencia de dinero en los cepillos hacían que los asaltantes determinasen su apropiación y reparto, como ocurrió en Vitoria, Adra (Almería), Formentera (Baleares), Busto de Bureba y Tardajos (Burgos), Hervás (Cáceres), Burriana y Oropesa del Mar (Castellón), Granada, El Almendro (Huelva), Guillena (Sevilla), Puig y Tabernes de Valldigna (Valencia) o Torres de Berrellén (Zaragoza). En Poliñá del Júcar (Valencia) fue el mismo alcalde el que repartió los objetos de culto de más valor entre sus correligionarios. Pocas veces eran recuperados por la fuerza pública, como ocurrió en Baeza (Jaén). Modalidad aparte eran los asaltos con la única finalidad de acallar las campanas de las iglesias. En las parroquias de varios pueblos se robaron los badajos de las campanas, como en El Hornillo (Ávila); Boltaña, Burceat, Costean y Hoz de Barbastro (Huesca); Ons y Viceso (La Coruña); o Esquivias (Toledo). En otros se utilizaron medios más expeditivos, robando las campanas como en Dordaño (La Coruña) y Morés (Zaragoza), atentando contra el campanario y derribándolas como en Asoveral (Huesca) y Benagalbón (Málaga), o aprovechando su poder de convocatoria mediante su traslado a otras dependencias, como hicieron los comunistas de Cantillana (Sevilla) instalando las campanas en su sede.

La tercera categoría agrupa los ataques contra edificios religiosos que no implicaron asaltos, así como los conatos de incendio, que representan un porcentaje más pequeño $(13,5 \%)$. La intensidad de la violencia desplegada fue menor en estos casos que en las categorías anteriores, pero eso no debería hacernos minusvalorar los desperfectos causados y, sobre todo, el impacto psicológico en el clero y los católicos. Los conatos de incendio implicaron casi siempre que las 
llamas prendían en partes del edificio, sobre todo en las puertas de madera, y el hecho de que quedaran en conatos no se debió casi nunca a la intencionalidad de sus autores sino a la intervención de la fuerza pública o grupos de católicos, que evitaron su propagación. En cuanto a los ataques, se han contabilizado desde los apedreamientos, que solían generar daños como la rotura de cristales y vidrieras, caso de un convento en Puente de Vallecas (Madrid), del Palacio Arzobispal de Pamplona, de las casas rectorales de Valdeverdeja (Toledo), Argañín (Zamora) o Alpartir (Zaragoza), o de iglesias en Garde (Navarra), Écija (Sevilla) y Barcience (Toledo), hasta ataques más graves como los tiroteos, caso de un convento de Nájera (Logroño), o la explosión de bombas y petardos, como ocurrió en edificios religiosos de Casas del Señor (Alicante), Montaos (La Coruña), Palmés (Orense) o Sagunto (Valencia).

Resulta, no obstante, muy significativo para determinar la naturaleza de la violencia anticlerical, que estos episodios supusieran un porcentaje seis veces menor con relación a los que implicaron un grado de agresividad mayor y, por tanto, consecuencias más graves. Tan importante como esto es que 184 ataques anticlericales, entre incendios, asaltos y otras agresiones, tuvieron lugar de manera simultánea, el mismo día o en la misma secuencia de hechos, a la violencia ejercida contra las sedes de los partidos del centro y las derechas, sindicatos católicos o profesionales ajenos a los de clase, asociaciones de propietarios, casinos, centros recreativos y periódicos de matiz conservador, así como domicilios particulares y comercios de destacados políticos locales de la oposición. Esto confirma que una parte de la violencia anticlerical no puede desligarse del acoso que en muchas localidades sufrieron los vencidos en las elecciones de febrero a partir de esa fecha. De todas formas, también abundaron los ataques aislados a edificios religiosos, de uno en uno, y este goteo generó incluso más pérdidas que las agresiones simultáneas a iglesias, conventos y otros centros religiosos un mismo día, por más que en la historiografía sean más mentados estos sucesos, que por su notoria gravedad y por desarrollarse la mayoría en ámbitos urbanos o semi-urbanos son mejor conocidos. Buen ejemplo fueron los sucesos de 16 de marzo en Albacete, que se saldaron con dos iglesias quemadas y una tercera que estuvo a punto de arder, así como el asalto y saqueo de un convento y la quema de varias imágenes y objetos de culto. ${ }^{33}$

\footnotetext{
${ }^{33}$ Estas quemas colectivas, en las que se cometieron más de tres ataques contra personas y bienes religiosos un mismo día, se extendieron a Caudete (Albacete); Alicante, Benejama, Elche, Torrevieja y Villena (Alicante); Almería y Adra (Almería); Palma de Mallorca (Baleares); Cádiz, Benaocaz, Grazalema, Jerez de la Frontera y Puerto de Santa María (Cádiz); Palma del Río (Córdoba); Granada; Baeza (Jaén); La Coruña y Santiago de Compostela (La Coruña); Logroño; Madrid y Alcalá de Henares (Madrid); Álora, Bobadilla, Casarabonela y Estepona (Málaga); Beniaján, Cehegín, Los Garres, Puente Tocinos y Yecla (Murcia); La Laguna (Santa Cruz de Tenerife); Écija y Lebrija (Sevilla); Valencia, Alcira, Carcagente, Requena y Tabernes de Valldigna (Valencia).
} 
La cuarta categoría engloba el derribo y destrucción de monumentos de carácter religioso fuera de las iglesias, conventos y casas rectorales, un 5,9\% del total. Consistieron la mayoría de las veces en la destrucción de las cruces de piedra que jalonaban las entradas y salidas de muchas localidades o que presidían sus plazas públicas o espacios abiertos en recintos religiosos, caso de Arévalo y Pedro Bernardo (Ávila), Los Corrales, Real de la Jara y Tomares (Sevilla), Montblanch (Tarragona), Escalona (Toledo), Busot y Cuart de Poblet (Valencia) o Zamora. A veces en un solo día eran eliminadas todas las existentes en un pueblo, como en Almagro (Ciudad Real), Calaceite (Teruel) o Piedralaves (Ávila). En San Juan de Aznalfarache (Sevilla), la cruz fue arrancada y quemada en la misma puerta del ayuntamiento. Pero también los destrozos se extendieron a otros lugares sagrados como cementerios, o hacia otras manifestaciones de tipo religioso fueran bien de carácter permanente - los altares, imágenes y hornacinas que adornaban el exterior de las fachadas de muchos domicilios particulares-, caso de Antequera (Málaga) u Onteniente (Valencia). Y también a las erigidas para festividades religiosas, caso de las cruces y otros adornos erigidos para Semana Santa, como en Villarreal (Castellón), San Felices de los Gallegos (Salamanca) o Alcazarén (Valladolid). En Valencina de la Concepción (Sevilla), militantes del PCE asaltaron el local donde se guardaban los pasos de Semana Santa, y los sacaron a la calle en medio de un fuerte aguacero, lo que les supuso algunos daños.

Por último, la categoría menos frecuente fue la de agresiones físicas al personal religioso, que supusieron el 3,1\% de los actos de violencia anticlerical. El carácter y contexto de estas agresiones eran bastante diversos. Podía generarse en el transcurso de reyertas políticas entre bandos contrarios y con carácter de represalia, como pareció ocurrir en Peñacerrada (Álava), donde el párroco fue apuñalado. Pero casi siempre se trataron de actos de intimidación con el fin de presionar al sacerdote para que se marchara del pueblo. Para ello se utilizaron medios diversos. El vicario de Altea (Alicante) fue tiroteado tras salir de misa, momentos después de que los agresores amagaran con asaltar su casa y el alcalde impidiera que entraran en el interior de la iglesia. El cura de Val de Santo Domingo (Toledo) fue golpeado por un grupo que le pedía que se ausentase del pueblo, un día después de que le hubiese estallado una bomba en la iglesia mientras oficiaba misa. Los sacerdotes de Zamora y Valbuena (León) recibieron fuertes palizas, quedando heridos de gravedad. Este tipo de agresiones fueron recurrentes. Un sacerdote de Villanueva de Algaidas (Málaga) fue víctima de disparos mientras oficiaba un entierro. Otros lo fueron en Moreda (Oviedo) y Carpio de Tajo (Toledo), mientras que el de Infiesto (Oviedo) fue herido de bala en el transcurso de un asalto a su casa. Otras veces las agresiones sucedían después de desórdenes de los que se culpaba al cura. En El Burgo (Málaga), el párroco 
fue golpeado por un grupo después de ser acusado de preparar una acción contra la iglesia para culpar al centro obrero. Acto continuo, el alcalde lo detuvo y lo echó del pueblo. En Villanueva del Trabuco, en la misma provincia, el sacerdote fue expulsado después de que su automóvil quedase carbonizado. No cabe duda que la violencia manifiesta contra el clero fue, en muchos casos, la culminación de coacciones menos visibles que habían propiciado el abandono por parte de cada vez más sacerdotes de sus parroquias entre febrero y junio de 1936. Excluyendo los párrocos expulsados por los alcaldes, a principios de abril la cifra de sacerdotes que abandonaron sus parroquias sobrepasó ya los 150 . A principios de junio, las enumeraciones de las últimas cartas enviadas desde los obispados a la Nunciatura indicaban que la cifra se había multiplicado por tres. No es exagerado afirmar, al contrario, que poco antes del inicio de la guerra, el balance de toda la primavera daba una cifra cercana a 500 curas que habían tenido que ausentarse temporal o totalmente de sus parroquias.

Otra de las situaciones en que se generaba violencia contra los clérigos era en el transcurso de asaltos a edificios religiosos, lo que suponía la extensión a las personas de una violencia que venía centrándose casi exclusivamente en los bienes muebles e inmuebles de carácter religioso antes de febrero de 1936. Quizás el acontecimiento más célebre sea el de los sucesos ocurridos en mayo en Madrid tras la propagación del bulo de los caramelos envenenados que, aparte del incendio parcial o total de una decena de inmuebles, concluyó con seis religiosas y tres sacerdotes gravemente heridos tras ser golpeados y arrastrados. Pero no fue el único caso. En los sucesos del 10 de marzo de Granada, donde se asaltaron e incendiaron varias iglesias junto a otros establecimientos, se propinó una paliza a un capellán. En mayo, en Cuenca, dos frailes fueron igualmente maltratados, quedando heridos de consideración, y algo parecido ocurrió en Zafra (Badajoz) con dos legos, mientras las comunidades a las que pertenecían desalojaban sus conventos tras no garantizarles el alcalde su seguridad.

En cuanto a la distribución territorial de esta violencia, conviene resaltar dos hechos. El primero es su notable extensión. En todas las provincias excepto dos, Palencia y Guipúzcoa, se contabilizaron actos de este tipo entre el 17 de febrero y el 16 de junio de 1936 y ni tan siquiera este último territorio se vería libre de ellos en el último mes antes de la guerra, como lo prueba el asalto y saqueo de una iglesia en Oñate a finales de junio. ${ }^{34} \mathrm{Y}$ en la gran mayoría de las provincias, nada menos que 38 , se desarrollaron cinco o más episodios de violencia anticlerical en los cuatro meses historiados.

\footnotetext{
${ }^{34}$ La Vanguardia, 23-VI-1936.
} 


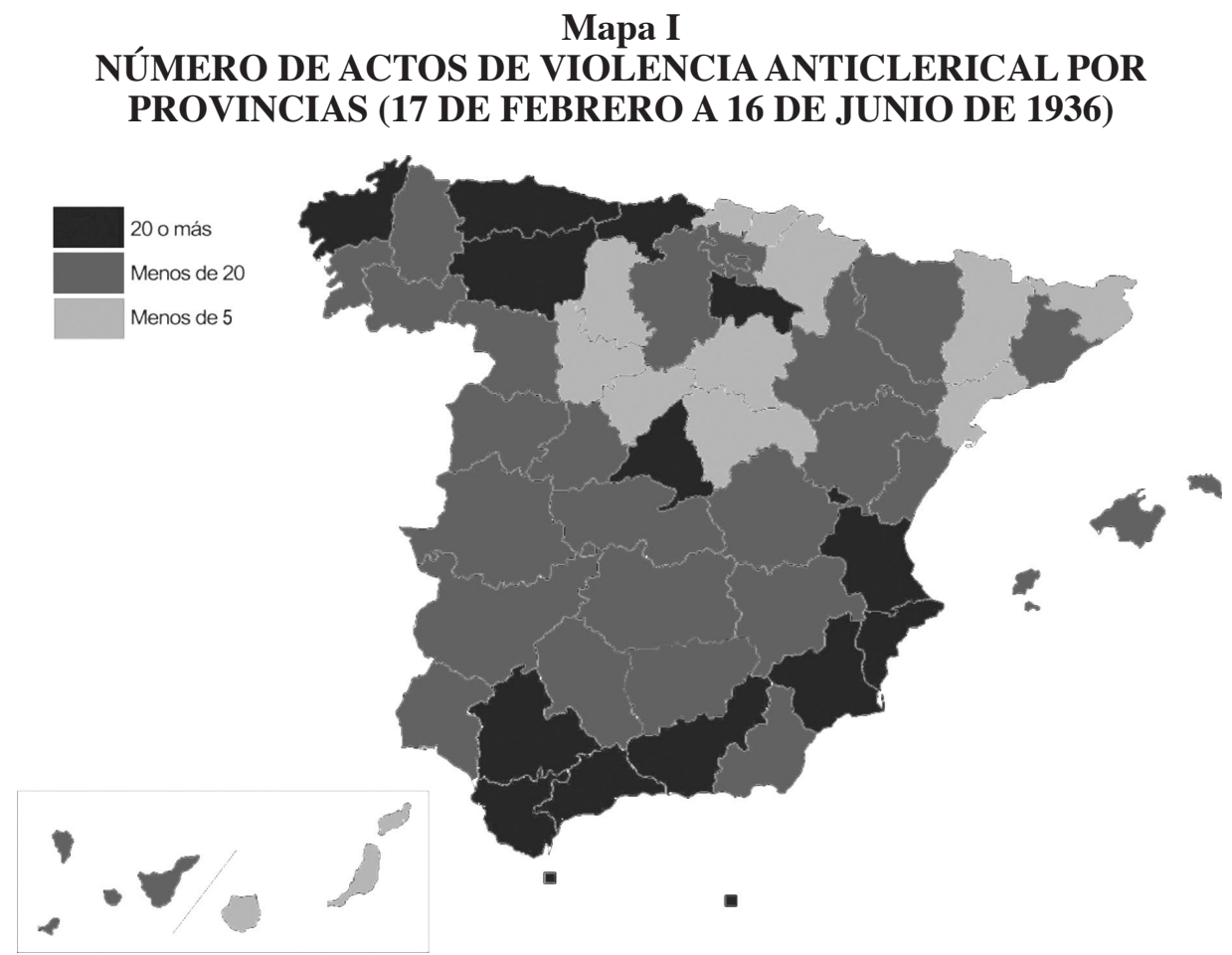

Datos elaborados a partir de Tabla I.

Siguiendo la división regional de la época, diez de las doce de provincias en las que apenas se desarrollaron actos de violencia anticlerical estaban concentradas en las regiones de Castilla la Vieja, Cataluña, Navarra y Vascongadas, sumándose a ellas las provincias de Guadalajara y Las Palmas. Sin embargo, de este hecho geográfico no pueden derivarse conclusiones rotundas, pues esas provincias convivían en el mismo marco regional que otras limítrofes donde este tipo de violencia no sólo fue mayor sino, caso de Castilla la Vieja, alcanzaron cotas máximas. Aún así, este grupo contrasta notablemente con el resto del país, pues sólo engloban 22 actos de violencia anticlerical, apenas un 2,3\%. Además, los actos que revistieron menor gravedad o que, al menos, quedaron en conatos debido a la intervención de la fuerza pública supusieron una proporción notoriamente mayor en estas provincias, contándose sólo una decena de edificios religiosos incendiados, asaltados o saqueados. Tampoco se registraron en esos lugares agresiones al clero. 
Tabla II

NÚMERO DE ACTOS DE VIOLENCIA ANTICLERICAL PERPETRADOS ENTRE EL 17 DE FEBRERO Y EL 16 DE JUNIO DE 1936. DISTRIBUCIÓN REGIONAL

\begin{tabular}{|l|c|c|c|c|c|c|}
\hline $\begin{array}{c}\text { Regiones en } \\
\mathbf{1 9 3 6}\end{array}$ & $\begin{array}{c}\text { Edificios } \\
\text { religiosos } \\
\text { incendiados }\end{array}$ & $\begin{array}{c}\text { Edificios } \\
\text { religiosos } \\
\text { asaltados } \\
\text { y/o } \\
\text { saqueados }\end{array}$ & $\begin{array}{c}\text { Agresiones } \\
\text { y conatos } \\
\text { de asalto e } \\
\text { incendio }\end{array}$ & $\begin{array}{c}\text { Derribo de } \\
\text { monumentos } \\
\text { religiosos }\end{array}$ & $\begin{array}{c}\text { Ataques a } \\
\text { personal } \\
\text { religioso }\end{array}$ & Total \\
\hline Andalucía & 44 & 128 & 31 & 14 & 4 & 221 \\
\hline Aragón & 4 & 17 & 3 & 3 & 0 & 27 \\
\hline Asturias & 18 & 12 & 3 & 0 & 2 & 35 \\
\hline Baleares & 2 & 2 & 3 & 0 & 1 & 8 \\
\hline Canarias & 0 & 3 & 7 & 0 & 0 & 10 \\
\hline $\begin{array}{l}\text { Castilla la } \\
\text { Nueva }\end{array}$ & 43 & 59 & 15 & 5 & 14 & 136 \\
\hline $\begin{array}{l}\text { Castilla la } \\
\text { Vieja }\end{array}$ & 47 & 15 & 12 & 8 & 0 & 82 \\
\hline Cataluña & 4 & 2 & 2 & 5 & 0 & 13 \\
\hline Extremadura & 2 & 4 & 2 & 4 & 2 & 14 \\
\hline Galicia & 32 & 44 & 16 & 2 & 3 & 97 \\
\hline León & 6 & 52 & 7 & 7 & 3 & 75 \\
\hline Murcia & 43 & 18 & 6 & 0 & 0 & 67 \\
\hline Navarra & 0 & 1 & 2 & 1 & 0 & 4 \\
\hline Valencia & 79 & 55 & 20 & 7 & 1 & 162 \\
\hline Vascongadas & 1 & 4 & 0 & 0 & 1 & 6 \\
\hline ESPAÑ & $\mathbf{3 2 5}$ & $\mathbf{4 1 6}$ & $\mathbf{1 2 9}$ & $\mathbf{5 6}$ & $\mathbf{3 1}$ & $\mathbf{9 5 7}$ \\
\hline
\end{tabular}

Datos elaborados a partir de Tabla I.

En el otro extremo, se distinguen un grupo de trece provincias especialmente conflictivas. Engloba cuatro andaluzas (Cádiz, Granada, Málaga y Sevilla), dos valencianas (Alicante y la propia Valencia), además de La Coruña, León, Logroño, Madrid, Murcia, Oviedo y Santander. Éstas fueron escenario nada menos que de 692 actos de violencia anticlerical, un 72,5\% del total. Este porcentaje tan elevado sugiere que, a pesar de su extensión, este fenómeno tuvo un impacto territorial desequilibrado y, por tanto, una incidencia especialmente agravada en una cuarta parte del país. Madrid destaca en primer lugar con un total de 89 actos de violencia, agrupando casi una décima parte del total nacional. No obstante, esas cifras son relativamente parejas a las de otras provincias con menor número de habitantes, como Valencia y Alicante (77 de actos de violencia cada una). Proporcionalmente, también 
resultan elevadas las de León (59), Cádiz y Murcia (57 cada una), La Coruña (56) y Málaga (52). Un criterio fundamental para medir el impacto de esa violencia es que los capítulos de agresiones especialmente graves destacan sustancialmente sobre los de menor entidad. Estas provincias agruparon el $82,5 \%$ de los incendios contra edificios religiosos - sólo Alicante ya supuso el 16,3\%-, el 71,8\% de los asaltados y saqueados, y el 61,3\% de las agresiones al personal religioso.

Si bien estas cifras abonan la existencia de un desequilibrio territorial claro en cuanto a la incidencia de la violencia anticlerical, sin embargo esto no debería llevarnos a concluir que ésta fue un fenómeno restringido a determinadas zonas. En las restantes 25 provincias la violencia anticlerical no fue tan intensa como el grupo anterior, pero sí estuvo presente en una medida no despreciable y precisamente este hecho le confiere un carácter general. Este segmento territorial intermedio agrupó un total de 240 actos de violencia en los 121 días que comprende la estadística, esto es, una media de dos actos de violencia diarios. Contabilizó 54 quemas de edificios religiosos, 110 asaltos con saqueo, y una docena de agresiones a clérigos, con lo que los ataques de especial gravedad supusieron casi tres cuartas partes de los episodios de la violencia anticlerical que se produjeron en esas provincias.

III. Muy pocos días llevaba instalado el nuevo Gobierno de Azaña en la Puerta del Sol cuando Federico Tedeschini, encargado de la Nunciatura en Madrid, se desplazó hasta la Presidencia para, entre otras atenciones protocolarias, mostrar el malestar de la Iglesia por «los desmanes ocurridos en la provincia de Alicante» durante la semana del recuento electoral. Azaña, en ese momento, se escudó en que «lo ocurrido se debía a falta de enlace entre las Autoridades de la situación anterior y las de la presente, de la cual falta habíanse aprovechado los facinerosos para cometer aquellos desmanes, pero que desde entonces el orden sería mantenido y respetado.»Y $\mathrm{Y}$ en privado reconoció que le «fastidiaban» esas quemas de iglesias y que parecían pagadas «por nuestros enemigos», aunque no dudó en decir a Giménez Fernández que los «atropellos y asaltos» contra centros y periódicos de la CEDA eran el «resultado fatal de una opresión de casi dos años».

Pero como los sucesos no cesaron, sino todo lo contrario, la segunda semana de marzo el Nuncio escribía al Presidente del Consejo totalmente desalentado. Le confesaba que las anteriores explicaciones de viva voz le habían hecho «concebir la esperanza de que una vez constituidos y asentados el nuevo Gobierno y las respectivas Autoridades locales, y dueños estos de todos los resortes, ningún atentado se repetiría». Y sin embargo, «lo triste y doloroso», añadía, «es que los deplorados excesos, no solo se han repetido, sino aún agravado, en diversos puntos de España». Además, se quejaba de algo que a buen seguro Azaña no hubo de encajar bien: en los sucesos de Cádiz había sido «a ciencia y paciencia 
de las Autoridades» que se habían «consumado inauditos atropellos contra la casi totalidad de los edificios religiosos»..$^{35}$

Pocas horas después Azaña recibía también otra extensa carta del cardenal de Tarragona, Vidal i Barraquer, que expresaba la «más enérgica y amarga protesta de la Iglesia» por unas «bárbaras violencias» que él consideraba que no eran «ajenas» a «las iniciativas públicas de las propagandas disolventes». Al igual que el Nuncio, se quejaba de la reacción de las autoridades, esto es, de «cuanto aparece visible la pasividad y negligencia en prevenirlas y reprimirlas por parte de quienes tienen el deber de garantizar el orden público y salvaguardar la seguridad, la libertad y el honor de los ciudadanos». Pero Vidal daba un paso más respecto de la diplomática carta de Tedeschini. Una vez afirmada con toda rotundidad que la Iglesia estaba «por encima de todo partidismo político» y que había «sido respetuosa con los poderes constituidos», terminaba sus líneas advirtiendo de que «de seguir las cosas por estos rumbos, se va a la anulación del poder público por la dejación de sus atributos en manos de la violencia agresora y de la reacción defensiva de la ciudadanía que nunca pierde su derecho natural de existir con seguridad y dignidad, y se va a la misma ruina de España, cuya vida y civilización no pueden subsistir sin la paz espiritual y civil que han de ser plenamente garantizadas por sus órganos estatales...». ${ }^{36}$

Sin duda, estas últimas palabras, de haber salido de la pluma de un prelado con una trayectoria antirrepublicana, habrían sonado a una clara amenaza de golpe de Estado, pero tratándose de Vidal, que tanto había trabajado porque la República y los católicos convivieran pacíficamente, la advertencia era significativa. No sabemos cómo se la tomó Azaña, aunque sí que no tardó en responder al Nuncio. Lo hacía el 17 de marzo y empezaba asegurando que el gobierno era «el primero en lamentar» los sucesos ocurridos. El presidente aseguraba que el ejecutivo no había cesado «ni un solo momento, de usar de los resortes que estaban a su alcance para evitar» los hechos que reseñaba el prelado. Es decir, Azaña no negaba la existencia de los mismos, aunque puntualizaba que el gobierno «ha[bía] logrado» evitar más violencia similar porque sus medidas habían sido eficaces y prudentes. Admitía, no obstante, que se habían iniciado «sanciones administrativas» en «aquellos casos en que apreció, no ya descuido, si no mera ineficacia por parte de algunas autoridades» ${ }^{37}$

También el ministro de la Gobernación, Amós Salvador, recibía una carta de la nunciatura fechada casi a la vez que la respuesta de Azaña. Tedeschini enumeraba las ciudades donde la violencia anticlerical era mayor, pero sobre todo

35 14-III-1936, Tedeschini a Azaña, ASV, Nunz. Madrid, b 925. Azaña, M. 1981. Memorias, Barcelona: Crítica. Vol. II: 18-21.

36 15-3-1936, Vidal i Barraquer a Azaña, ASV, Nunz. Madrid, b 925.

37 17-III-1936, Azaña a Tedeschini, ASV, Nunz. Madrid, b 925. 
señalaba que si bien el gobierno le había asegurado, por carta y de viva voz, que los «desmanes no habían de repetirse», lo cierto es que, a su juicio, «una ola verdaderamente vandálica, destruyendo iglesias y conventos» había recorrido España de nuevo. Así, «después de las reiteradas declaraciones del Gobierno de evitar a todo trance sucesos y desmanes, cerca de 30 entre iglesias, ermitas, conventos y alguna casa parroquial han sido incendiadas y saqueadas» entre la segunda y la tercera semana de marzo. Por eso a Tedeschini le parecía que era ya hora de evitar que se pudiera decir dentro y fuera de España que «la Autoridad asiste pasiva a la perpetración de los sacrílegos crímenes». ${ }^{38}$

El ministro de Gobernación le respondía una semana más tarde, ya algo más calmada la situación en la capital tras las luctuosas jornadas posteriores al atentado contra Jiménez de Asúa, aunque todavía con numerosos problemas en otras provincias. Ese mismo día, el 25 de marzo, también cursaba su carta de respuesta el ministro de Estado, Augusto Barcia. El primero decía hablar en nombre del gobierno al lamentar lo ocurrido y asegurar que había por su parte una «decidida voluntad» de adoptar «medidas gubernativas» para mantener el «orden público». El segundo, por su parte, recordaba que el gobierno «no ha[bía] omitido ... ninguna ocasión para llamar a todos a una convivencia fraternal» en las que se respetasen «todas las ideologías, creencias y confesiones». Ahora bien, ambos ministros trasmitían además una preocupación, expresada de forma más clara en Barcia e implícita en Salvador: todos debían contribuir al orden y todos debían «dejar al margen cuanto pu[diera] conducir a la excitación de ánimos o a malas inteligencias». Es decir, el gobierno pedía a la Iglesia que se extendieran «las predicaciones oportunas y discretas» que llevase a «los creyentes» por el camino de «la ponderación». Es más, para Barcia, el problema que podría estar detrás de algunas violencias era que en «medios rurales de escaso nivel cultural» las predicaciones inadecuadas de los curas habían provocado «reacciones populares que, al degenerar en motines, [eran] difícilmente controlables» y daban lugar a «excesos». Por eso, el ministro pedía expresamente a Tedeschini, en nombre del Gobierno, que los Prelados hicieran las oportunas «sugestiones» a los «Sacerdotes de sus respectivas Diócesis colaborando a que se pacifiquen las conciencias, se apacigüen los ánimos y se serenen los espíritus»..$^{39}$

Más adelante, después de un nuevo aumento de la violencia anticlerical en los primeros días de mayo, Tedeschini escribía de nuevo al ministro de Estado. Era una carta más extensa que las anteriores y especialmente sincera. En su opinión, el número de «desmanes antirreligiosos» «no sólo no [tendía] a disminuir, sino que al contrario, se ha[bía] visto aumentar en proporciones desoladoras». Por eso, y pese a las promesas del gobierno, la Iglesia no ocultaba

\footnotetext{
38 18-III-1936, Tedeschini a Salvador, ASV, Nunz. Madrid, b 925.

3918 y 25-III-1936, Salvador y Barcia a Tedeschini, ASV, Nunz. Madrid, b 925.
} 
su «desorientación y desaliento». Influían en el ánimo de Tedeschini no ya los «tristísimos sucesos de los días 3 y 4 del actual en Madrid» sino esos «frecuentes y gravísimos atropellos cometidos con sacerdotes y en particular con religiosas» en diferente partes del país. Sin duda, Tedeschini no ocultaba ya una indignación más exacerbada, si cabe, y lanzaba su dardo directamente contra el gobierno: este, escribía, no sólo conoce la «cuantía, la gravedad, la reiterada persistencia de esos desmanes» sino que sabe «las causas de los mismos» y «los motivos porque no se toman prevenciones, ni remedios, ni se aplican sanciones radicales y seguramente eficaces». La acusación no podía ser, pese al conducto diplomático, más clara y rotunda: el gobierno sabía lo que estaba pasando y por qué, decía el Nuncio, pero no tomaba las medidas necesarias. Es más, el Nuncio no ocultaba a Barcia que: «La impresión que producen muchas relaciones fidedignas, y aún documentos gráficos es que, en la mayoría de los casos se deja hacer impunemente; y es más, como si esos desmanes no fueran materia delictiva, apenas se investiga acerca de los autores, generalmente públicos y conocidos de todo el pueblo: apenas se detiene y se castiga a nadie creando, y duele mucho el tener que decirlo, lo que en semejantes casos suele ser (...) el principal factor y aliento para la reiteración de tan graves sucesos. Y cuando la Autoridad se resuelve a intervenir, en muchos casos lo ha hecho encarcelando, no a los culpables, sino a las mismas víctimas y entre ellas a venerables sacerdotes».

Pero no era sólo esto. También se lamentaba Tedeschini de que las amenazas de muerte y las variadas coacciones y maltratos a algunos párrocos, hasta conseguir expulsarlos, estuvieran pasando sin «la necesaria defensa por parte de la Autoridad». Y añadía dos agravios más, ante los que también le parecía insuficiente la acción del gobierno. Por un lado: «Muchas autoridades locales y provinciales están procediendo en todo lo que se refiere a la libertad religiosa y a los derechos de la Iglesia y de los católicos, con un total desprecio de la misma Constitución de la República y de las Leyes, y con una anárquica autonomía, que las lleva a adoptar e imponer a su antojo las más arbitrarias medidas». De otro: «Entre los múltiples atropellos cometidos merecen destacarse por su significación y gravedad los intentos... de los elementos extremistas, secundados a veces por Alcaldes y Ayuntamientos, de apoderarse de iglesias, conventos y colegios católicos, para instalar en ellas Casas del Pueblo, escuelas laicas, salones de baile; o para otros fines cualesquiera.» «Este estado de cosas», concluía el Nuncio, «ya no puede atribuirse a imprevisión y sorpresa, sino que se viene aguantando desde más de tres meses, con longanimidad superior a cuanto puede razonablemente pedirse».

Esa situación, lo creyera o no el Nuncio, se prolongó durante algunas semanas más, a juicio de la última comunicación que éste envió al Gobierno justo antes del estallido de la guerra. Algo más tarde del 10 de julio recibía Barcia la última protesta ante la «continuación de tales desmanes y atropellos, todavía 
numerosos y tristísimos», en la que se llamaba la atención «sobre el aspecto gravísimo que la situación religiosa reviste en algunos Diócesis de España, como las de Málaga, Valencia, Granada, Toledo, Astorga, etc., en las que se hace imposible, en muchos pueblos, toda vida religiosa y todo ejercicio del culto». ${ }^{40}$

A la luz de los datos que hemos recopilado, no parece que las protestas del Nuncio estuvieran desprovistas de fundamento. Es más, sólo por el volumen de la violencia cabe deducir que la reacción de las autoridades fue como poco ineficaz. Sin embargo, algunos interrogantes importantes requieren respuestas más complejas. ¿Se cometieron todas esas violencias pese a la reacción del gobierno o por el contrario este se mostró pasivo o poco decidido de forma generalizada? ¿Podía quejarse la Iglesia, como insinuaba una de las últimas notas de Tedeschini, de inacción gubernativa?.

El 8 de marzo Cádiz había sido una de las ciudades donde la violencia anticlerical había estallado con más fuerza. El obispo de la diócesis escribía al Nuncio un día después para contarle que «desde las dos de la tarde hasta las nueve de la noche» habían sido «asaltados algunos edificios religiosos» e incluso la «propia residencia Episcopal». Pese a los «destrozos de importancia», no había que lamentar «desgracias personales». El obispo se quejaba de que todo eso había ocurrido «a ciencia y paciencia de los que por obligaciones sacratísimas de su cargo debieron impedirlo». ${ }^{41}$

El obispo, en este caso, no exageraba. Según la información censurada a la prensa, las fuerzas del orden se desplegaron y llegaron a «situarse frente a los edificios», pero no actuaron. Sólo tras una conversación entre el comandante militar de la plaza, coronel Herrera, y el gobernador civil, salieron algunas fuerzas del Ejército, aunque para entonces nada menos que ocho iglesias, cuatro conventos y tres colegios habían sido asaltados y quemados. En los casos de los colegios el protagonismo no había sido de las masas revolucionarias sino de algunos dirigentes comunistas, que alegando una disposición de Marcelino Domingo en la que se requerían datos sobre las posibilidades de sustitución de la enseñanza religiosa, habían exigido una incautación inmediata de los centros. El Gobernador sólo se decidió a intervenir después de mucho tiempo de discusiones; su decisión, paradójicamente, fue obligar a los religiosos a abandonar el colegio y clausurarlo por orden «del Gobierno».

\footnotetext{
${ }^{40}$ Hay una primera copia escrita en torno al 4 o 5 de julio probablemente de la mano del propio Tedeschini, y cuya copia fue enviada a Pacelli. Sin embargo, la nota que realmente se envió al gobierno se pulió en torno al 10 de julio, ya cuando Tedeschini había dejado la embajada camino de Roma. La diferencia más sustancial entre ambas notas es que la primera empezaba con una frase que luego fue tachada del segundo borrador: «Aunque en estas últimas semanas se hayan atenuado algo la ola de desmanes y atropellos antirreligiosos». ASV, Nunz. Madrid, b 925.

41 9-III-1936, Carta del obispo de Cádiz a Tedeschini. ASV, Nunz. Madrid, b 925.
} 
A primeros de mayo el obispo de Badajoz relataba al Nuncio lo ocurrido en la ciudad de Zafra la tarde del día 2 y la madrugada del 3. Allí unas cuantas decenas de religiosos habían tenido que abandonar sus casas en situaciones parecidas. Grupos de la izquierda obrera habían organizado protestas o manifestaciones y el alcalde, «ante la imposibilidad en que se encontraba de dominar el tumulto», les había conminado a abandonar la ciudad por no poder garantizar su seguridad. El obispo recordaba, asimismo, que horas antes había contactado con «el Gobierno Civil a favor de los PP. Misioneros» y que «el Secretario particular del Gobernador, en ausencia de éste» le dijo que «habían concentrado fuerzas y que estuviera tranquilo». Sin duda, como estaba ocurriendo en otras localidades, las promesas de protección no tuvieron efecto alguno. La simple presencia de la policía, sin órdenes expresas de actuar, no era suficiente.

El Superior del Colegio de Misioneros Hijos del Corazón de María de la ciudad de Zafra, Saturnino González, fue bastante más explícito en el relato de los hechos que envió al gobernador de Badajoz. Según su testimonio, la expulsión de los más de sesenta religiosos, la mayoría «clérigo estudiante», había venido precedida de «agravios» y «malos tratos a un lego de la misma» desde el 25 de abril en adelante. Después de algunas manifestaciones hostiles convocadas por «comunistas o socialistas», el Superior pidió protección a las autoridades, pero no tuvo respuesta hasta el 30 de abril, cuando decidió acudir «por teléfono» al Gobernador Civil de la Provincia, «quien ordenó al Teniente de la Guardia Civil defendiese nuestra casa». Pero esa defensa sólo duró «la noche del día 30». De tal forma que el colegio estaba desprotegido cuando se celebró la manifestación del 1 de Mayo y hubo, primero, «una gran pedrea» a las ocho de la noche, y más tarde, a las once, el asalto a la huerta del colegio. Al final «llegaron los guardias de Asalto» y la violencia no fue a más. Pero el día 5, tras una manifestación de «mujeres» frente al Colegio, a las cinco de la tarde se presentó una comisión presidida por el alcalde, al que acompañaba el jefe de policía. La máxima autoridad local, alegando que «la excitación del pueblo» era incontenible, exigió la salida de «todos los religiosos»; de no hacerle caso, «no respondía de lo que podía suceder a la Comunidad». Según el testimonio del Superior, las cinco llamadas previas al alcalde y el intento de comunicación con el Gobernador no surtieron efecto alguno. La conclusión que envió al Gobernador era bastante elocuente: «sin dejar de reconocer la protección de la autoridad en casos dados, no nos hemos sentido amparados por ella, como deben ser amparados los ciudadanos que cumplen las leyes de la República». ${ }^{42}$

Una situación parecida se repitió en el centro de los Padres Misioneros de Almendralejo el 1 de mayo. Un grupo asaltó el colegio de niños que regentaban

42 5-V-1936, José María, Obispo de Badajoz a Tedeschini. 6-V-1936, Saturnino González al Gobernador de Badajoz. ASV, Nunz. Madrid, b 925. 
e intentaba prender fuego al edificio. Al poco, «los Guardias de Asalto» se presentaron para realizar «un minucioso registro por creer que había armas escondidas» y encontraban «una bala, pero ninguna arma». Acto seguido, «Todos los Religiosos» eran «detenidos». ${ }^{43}$ Estos sucesos de Badajoz daban lugar a una nota enviada por el Nuncio al ministro Moles el 16 de mayo, mediante la que se pedía la intervención del Gobierno para «reparar con la mayor eficacia y urgencia estos atropellos». ${ }^{44}$ Pero Tedeschini no tendría respuesta de Gobernación, sino de Estado. El ministro Barcia le escribía una semana más tarde, no para referirse a los hechos concretos de Badajoz sino para abroncar al Nuncio por haberse dirigido directamente al ministro de la Gobernación y no seguir los cauces diplomáticos habituales. Barcia añadía que su Ministerio «procurará, como constantemente ha venido y ha de continuar haciéndolo, dar el rápido curso que corresponda» a los escritos del Nuncio. Tedeschini, como consta en la copia que envió a Pacelli, reaccionó con una mezcla de ironía y escepticismo subrayando y poniendo signos de interrogación a estas últimas palabras de Barcia. ${ }^{45}$

Otro episodio importante para calibrar la reacción de las autoridades y la intervención de la policía ocurrió en la ciudad de Yecla, donde el 16 de marzo fueron incendiadas y destruidas nueve iglesias, una casa rectoral y un convento, todo a la par que se asaltaban los círculos de labradores, el sindicato católico, el local de AP y varios domicilios particulares. Según el testimonio que envió a Gil Robles un sacerdote de la localidad, desde el día 16 «se notaba mar de fondo y marejada grande en el elemento obrero y campesino», pero de nada sirvieron los «18 guardias civiles, cuatro carabineros y 15 guardias de asalto» que podían haber «evitado estos sucesos». No lo hicieron «por la pasividad de las autoridades locales.» A su juicio, los «guardias de asalto [fueron] figuras decorativas, que aunque vieron quemar y destruir, no intervinieron», si bien los «guardias civiles» permanecieron, significativamente, «acuartelados», aunque «las turbas» llegaron a rodear el cuartel y a proferir todo tipo de amenazas. ${ }^{46}$

El relato posterior preparado por El Debate y, según parece, censurado, aseguraba que a finales de ese mes de marzo, habían huido de Yecla «mil quinientas familias» y no menos de «once sacerdotes». Todo había empezado, según testimonio del gobernador José Calderón Sama, la tarde del día 17, cuando un vehículo conducido por el jefe de Falange de Murcia, Federico Servet, había circulado a toda velocidad por la localidad realizando varios disparos. Para El Debate, sin embargo, nada de eso se había podido confirmar

${ }^{43}$ José María, Obispo de Badajoz, al Nuncio. 10-V-36, ASV, Nunz. Madrid, b 925.

${ }^{44}$ 16-V-1936, Tedeschini a Moles, ASV, Nunz. Madrid, b 925.

45 23-V-1936, ASV, Nunz. Madrid, b 925.

${ }^{46}$ Yecla, 18-III-1936, testimonio remitido por el Obispo de Cartagena a Francisco de Luis y Díaz, director de El Debate. ASV, Nunz. Madrid, b 912.

Hispania Sacra, LXV

132, julio-diciembre 2013, 683-764, ISSN: 0018-215X, doi: 10.3989/hs.2013.033 
y «Sólo se buscaba un pretexto para poder justificar los graves sucesos que horas después comenzaban a registrarse» y que además se habían cobrado la vida de «un joven fascista que fue asesinado a hachazos». De hecho, a decir de esta misma fuente, a la vez que empezaban a arder edificios religiosos, el gobernador «dirigía desde su despacho una alocución por radio, diciendo que castigaría toda clase de desmanes, que el orden era perfecto y que los pequeños incidentes registrados habían sido promovidos por las provocaciones de elementos facciosos contra la República». ${ }^{47}$

No fue muy diferente lo ocurrido en Elche pocos días después de que concluyera la jornada electoral del 16 de febrero. Cuatro iglesias y un convento fueron asaltados o incendiados, en un contexto en el que nuevamente la violencia anticlerical acompañaba a los ataques sobre las sedes o las personas vinculadas a las derechas locales y a los republicanos radicales. El jueves día 20, al mediodía, nada más tomar «posesión el Ayuntamiento del 14 de abril» se formó una «manifestación tumultuosa» que derivó en las violencias mencionadas, no sin antes causar graves heridas a un teniente de Asalto, José Sánchez Meseguer, que intentó «disuadir a los grupos incendiarios» y que al defenderse con su arma dio lugar a un intercambio en el que hubo no menos de dos muertos. Tras varios asaltos, incluido el local del «partido del señor Chapaprieta», el alcalde socialista, Manuel Rodríguez, intentó «disuadir a la turbamulta enloquecida». Sin embargo, la «fuerza pública, sin órdenes para otra cosa, dejó hacer», mientras que el jefe de la Guardia Municipal «fue brutalmente apaleado». ${ }^{48}$

Elche siguió siendo fuente de problemas para la Iglesia en las semanas siguientes. Todavía a mediados de abril el Administrador Apostólico de Orihuela escribía al Nuncio para informarle que el ayuntamiento «que vive y actúa bajo la inspiración comunista» actuaba al margen de la legalidad. A su juicio, de poco servían las «órdenes del [Gobernador]». Tedeschini remitía a su vez esa queja al ministro Barcia, haciendo hincapié en que «las órdenes que le ha dado el Sr. Gobernador de Alicante» al alcalde no han impedido el inicio de la demolición de una de las iglesias quemadas en las semanas anteriores. El ministro le contestaría ya a comienzos de julio negando que los hechos denunciados tuvieran «el carácter y el alcance que se les atribuía», señalando que se trataba de unas obras necesarias para impedir un derribo inesperado y peligroso. ${ }^{49}$

Los ejemplos descritos hasta ahora ponen de manifiesto una característica de la política de orden público que se siguió en algunos episodios anticlericales

\footnotetext{
${ }^{47}$ Fragmentos de El Debate, 31-III-36, ASV, Nunz. Madrid, b 912.

${ }^{48}$ Fragmentos de El Debate, según información remitida al Administrador Apostólico de Orihuela. En ASV, Nunz. Madrid, b 912.

49 Alicante, 19-IV-1936. ASV, Nunz. Madrid, b 912. Nota verbal a la Nunciatura Apostólica en España, Madrid, 22-IV-1936. La respuesta del gobierno, Madrid, 2-VII-1936. ASV, Nunz. Madrid, b 912.
} 
de la primavera de 1936, especialmente en aquellas poblaciones donde la violencia alcanzó mayores proporciones: la reacción de las autoridades fue como mínimo tímida. Esto es, o bien no actuaron de inmediato para cortar en sus inicios cualquier acción ilegal, o bien dejaron que la policía estuviera en la calle pero sin órdenes expresas y tajantes para que reprimiera las violencias. Junto a eso, también se observa, tanto en los casos de Elche como en los de Badajoz, una complicación añadida por la tendencia de algunas autoridades locales a actuar conforme a su propia voluntad e incluso a desobedecer las órdenes de gobernadores poco resueltos.

Este patrón de reacción tibia y tardía o incluso, en los casos extremos, de pasividad ante la actuación de los asaltantes e incendiarios se repitió en situaciones en las que la violencia adquirió proporciones muy graves y tuvo, a medio plazo, consecuencias importantes para la convivencia en esas provincias, dado que la quema de iglesias o los asaltos a locales religiosos eran, en ocasiones frecuentes, parte de una violencia más amplia dirigida contra las asociaciones, la prensa y los partidos de derecha y centro-derecha. Este fue el caso de Cádiz ya mencionado, pero el patrón se repitió en muchas localidades. En La Coruña, pocas horas después de la jornada electoral del 16 de febrero, el sacristán de la iglesia del Sagrado Corazón, que fue incendiada, fue maltratado «en presencia del capitán de Asalto.» En Alcalá de Henares, el día 5 de marzo «grupos de extremistas» asaltaron y provocaron fuegos en dos iglesias y un convento, sin que la policía interviniese. A mediados de marzo, en varias localidades de Murcia los guardias de Asalto «permanecieron totalmente impasibles» ante el incendio y asalto a varias iglesias. La tarde del día 17, en Albacete, una manifestación del Frente Popular derivó en asaltos e incendios de locales católicos, periódicos, asociaciones privadas, un local de AP y varias iglesias, todo eso ante una «fuerza pública» que, según el recorte de prensa censurado, «se muestra pasiva».

En Madrid se reprodujeron circunstancias similares el 10 de marzo, cuando grupos de violentos «destruyeron impunemente, ante la fuerza pública», un convento, un centro obrero católico y un local de Acción Popular en la zona del Puente de Vallecas. Cuando los bomberos llegaron a sofocar uno de los incendios, fueron acogidos «con muestras de desagrado y (...) hubieron de alejarse». Frente a un convento de las Hermanas Pastoras guardias de Asalto «acordonaban el convento» pero no impidieron que los violentos «se dedicaron a sacar cuanto encontraban dentro». Pese a la presencia de varios caminos de Asaltos y Guardia Civil, la pasividad fue total ante el asalto e incendio de la casa particular de un dirigente de Acción Popular, Fernando Cascales, del que se dijo que había disparado a las turbas «desde su casa». ${ }^{50}$

${ }^{50}$ ASV, Nunz. Madrid, b 945 y b 925. AHN (Salamanca), P-S Madrid, L. 152 y 1536. 
Otro tanto ocurrió en Granada, donde la violencia fue especialmente grave y prolongada el 10 de marzo. Cuando empezaron los incendios, no sólo en los edificios religiosos sino también en centros políticos, periódicos o en fábricas, como la de Francisco Rodríguez, presidente de Acción Popular, «los bomberos salieron a sofocar los incendios, pero las masas se lo impidieron» y la policía «tuvo que amenazar a los bomberos para que prestaran sus servicios, ante el temor de que las llamas alcanzasen a los edificios colindantes». Sin duda, los guardias de Asalto actuaron en diversos puntos de la ciudad, con intercambios de disparos, pero se inhibieron cuando se produjo el asalto a la sede del periódico Ideal. En este último caso hubo «varios guardias que no intervinieron en lo más mínimo y dejaron a las masas incendiar y saquear a su antojo». Y lo mismo ocurrió horas más tarde cuando, ya con la huelga general declarada y tras varios incendios y asaltos, las calles se iban quedando desiertas. «La fuerza pública», puede leerse en la información censurada, «adopta una actitud totalmente pasiva». Y horas más tarde se informa ya del despliegue de la Guardia Civil, con «intenso tiroteo en el centro de la ciudad». ${ }^{51}$

Y llama la atención que incluso en Madrid los terribles sucesos que se produjeron al circular el bulo de los caramelos envenenados en los días 3 a 5 de mayo tuvieran lugar durante horas, sin que la policía los atajara pronto, tratándose como se trataba de la capital y, por tanto, de un lugar donde la presencia de agentes y su rápido desplazamiento no eran un problema. Aunque el rumor había empezado el día 1 y hubo agitación en la calle desde la tarde del 3, no parece que la Dirección General de Seguridad pensara en actuar de forma preventiva, aun cuando sí se observa la participación de algunos líderes de izquierdas, como Wenceslao Carrillo, en medio de alguna de las manifestaciones para negar los rumores y calmar los ánimos. La noche del día 3 la Guardia de Asalto consiguió dispersar a un grupo de incendiarios frente a la parroquia de Nuestra Señora de los Ángeles y así pudieron actuar los bomberos. Pero hubo agresiones muy graves en las que no intervino la policía y a mediodía del 4 algunos edificios habían sido asaltados o incendiados. Casares se lamentó «de que la credulidad del pueblo ante los bulos» diera lugar a «alteraciones de orden público», pero no mostró una determinación muy firme en las primeras horas de los sucesos y no dejó de señalar, quizá para no disgustar al «pueblo republicano», que esos bulos habían sido «propalados por extremistas de uno y otro sector». Es decir, el propio gobierno planteaba la sospecha de que los derechistas hubiesen actuado ex profeso para incitar la violencia y fomentar el desorden.

Este tipo de argumentos los había usado el ministro Barcia ante el embajador británico, sir Henry Chilton, para comentar los incendios de mediados de marzo

${ }^{51}$ ASV, Nunz. Madrid, b 925 y b 912 . Villa García, R. 2009. «The Failure of Electoral Modernization: The Elections of May 1936 in Granada». Journal of Contemporary History 44 (3). 
en Madrid: «el mismo clero», le dijo, «tenía en gran parte la culpa (...) puesto que varios sacerdotes habían disparado a la multitud, mientras que a otros les habían encontrado armas de fuego y este hecho había enfurecido a la muchedumbre, que, por consiguiente, quemó algunas iglesias.» Esta era una forma de excusar la violencia que, como venía ocurriendo desde 1931, estaba bastante generalizada entre la izquierda republicana y sus aliados socialistas. No en vano, El Socialista había denunciado a mediados de marzo que en las iglesias había «reuniones clandestinas» y había advertido, poco después del incendio de la iglesia de San Luis, que «el pueblo [sabía] de sobra a qué procedimientos ofensivos [era] capaz de recurrir la Iglesia militante».

Lo que no le dijo Barcia al embajador ni al Nuncio fue que el director general de Seguridad, José Alonso Mallol, tenía información previa de que los comunistas estaban planeando incendiar la iglesia de San Luis y decidió no hacer nada, o más bien dejar hacer al «pueblo». Además, el mismo Alcalá Zamora, todavía Presidente de la República, anotaba en su diario el día 14 de marzo que los incendiarios habían «prendido fuego a su antojo desde la caída de la tarde, sin encontrar resistencia, ni aun en la iglesia de San Luis, que está a la vista del Ministerio de la Gobernación». Con todos estos antecedentes no resulta muy convincente la declaración que Casares hizo en las Cortes a propósito de la violencia de mayo en torno al bulo de los caramelos envenenados. El ministro condenó «los lamentables sucesos ocurridos en Madrid» y se felicitó por cortarlos a tiempo. Aunque no dijo que la policía había detenido a ninguno de los agresores ni explicó si la dimisión del coronel jefe de los guardias de Asalto, Puigdengola, presentada el día 5 , tenía algo que ver con esos hechos. ${ }^{52}$

Parece probado, por tanto, el hecho de que en algunos casos importantes de violencia anticlerical durante los meses de febrero a mayo de 1936 la intervención de las fuerzas de seguridad no fue suficientemente rápida, o incluso dejó que los violentos actuaran, no produciéndose de forma habitual detenciones posteriores de los responsables. El gobierno, por otra parte, tal y como le transmitía en privado al Nuncio, se escudó en que parte de esas violencias habían venido precedidas de provocaciones previas. Y nunca reconoció públicamente lo que sí le dijo el ministro de la Gobernación a Alcalá Zamora en privado, horas después del incendio de la iglesia de San Luis en marzo. Le aseguró, cuando ya habían pasado los episodios más lamentables, que «por fin» habían resuelto «hacer frente a los disturbios» y que, «hasta ahora, la fuerza tenía consigna de

${ }^{52}$ Casares, en La Gaceta del Norte, 6-V-1936. Cit. en González Gullón, J. L., El clero...: 399-408. Alcalá Zamora, N. 2011. Asalto a la República. Enero-Abril de 1936. Madrid: Esfera de Libros, 289. El subrayado es nuestro. Barcia al embajador, en The National Archives, FO371/20520/»2868/62/41; la información de Mallol, en el testimonio del Comisario jefe Joaquín García Grande Villaverde, en Causa General, 1513, Exp. 26. Estas dos últimas referencias, en Ruiz, J. 2012. El terror rojo, Barcelona: Espasa, 40 .

Hispania Sacra, LXV

132, julio-diciembre 2013, 683-764, ISSN: 0018-215X, doi: 10.3989/hs.2013.033 
no disparar». El ministro, para asombro del Presidente, añadió que puesto que esa consigna «se sabía», incluso la policía había sido tiroteada y burlada. ${ }^{53}$

Sin embargo, pese a estas evidencias tan esclarecedoras, no se puede concluir que, de forma generalizada, las fuerzas de seguridad y los gobernadores no actuaran o lo hicieran tarde. Las situaciones variaron en función de distintos factores; entre estos, uno importante fue la determinación de los gobernadores para hacer cumplir la ley, incluso al margen de la tibieza del ministro de turno. Sin duda, algunos casos muestran que la violencia de ciertos grupos podía ser parado a tiempo si había voluntad política para tomar las medidas oportunas. Es evidente que cuando, como le dijo el ministro a Alcalá Zamora, la policía tenía órdenes precisas de impedir los ataques incendiarios a cualquier precio, ésta difícilmente se producía. Así, en Bilbao el 18 de marzo la policía disolvió una manifestación de comunistas que había rodeado un convento y que gritaban amenazadoramente: «U. H. P., arderá Jesús». En las dos jornadas incendiarias ocurridas en Madrid entre el 10 y el 12 de marzo, si bien ardieron muchos edificios y se produjeron agresiones graves, bastaron «algunos disparos al aire» de los guardias civiles para impedir el asalto a un convento de la carretera de Valencia o a una casa de religiosas de la calle del Pacífico. Y tras el incendio de la iglesia de San Luis, cuando Gobernación ya había dado a la policía órdenes de actuar, un grupo de extremistas que llegaron hasta la iglesia de los Jerónimos fueron detenidos y abortado el asalto. ${ }^{54}$ En Ronda, a las pocas horas de la jornada de votaciones, la Guardia Civil intervino para impedir el asalto a dos parroquias. La segunda semana de marzo, en Sevilla capital una manifestación derivó en violencia y asalto a comercios, pero la Guardia Civil intervino a tiempo e impidió incendios y asaltos de iglesias. Algo parecido pasó en Écija un día más tarde. En Pamplona, el día 23 de ese mismo mes el Gobernador fijó un servicio de vigilancia para impedir el asalto al Palacio Arzobispal. En Redobán (Alicante) la «llegada de la fuerza pública pudo evitar que los sucesos fuesen mayores», aunque «los extremistas se irritaron por ello y promovieron una manifestación tumultuosa». El Gobernador de esta provincia aseguró a los periodistas que, «de acuerdo con las órdenes recibidas, mantendr[ía] inflexiblemente el orden público», por lo que había ordenado «que las iglesias y edificios públicos est[uvieran] vigilados por guardias de Asalto y de Seguridad.» Finalmente, el gobernador de Valencia fue implacable con un alcalde díscolo que había tolerado, en Silla, una manifestación y un asalto a la iglesia parroquial. «Enterado de lo que ocurría el gobernador, señor Solsona, llamó por teléfono al alcalde de dicho pueblo y le dio cinco minutos de plazo para que restableciera la normalidad, disolviendo la manifestación. A los dos minutos escasos el señor

\footnotetext{
${ }^{53}$ Alcalá Zamora, Asalto a la República...: 290.

${ }^{54}$ ASV, Nunz. Madrid, b 912. González Gullón, El clero...: 392-393.
} 
Solsona recibía de boca del alcalde la noticia de que la tranquilidad se había restablecido. No obstante, salieron veinticinco guardias de Asalto, que no tuvieron que intervenir». ${ }^{55}$

No obstante, los informes de Gobernación confirman que la marejada de sucesos anticlericales, 957 actos en 121 días, fue facilitada por las vacilaciones y la falta de respuesta uniforme por parte de las mismas autoridades, las órdenes inoportunas de acuartelamiento o retirada de la fuerza pública y, en algunos casos, por la misma complicidad de parte de esas autoridades con los promotores de esa violencia. Los frecuentes enfrentamientos entre algunos gobernadores y alcaldes en varios de los sucesos de violencia anticlerical, explicitados en varios documentos y telegramas, son la muestra más evidente. Caso significativo fue la multa que impuso el gobernador de Huesca al alcalde de Lascellas por haberle dirigido un oficio preguntándole «si podría encontrarse algún procedimiento para eliminar al Cura». Otros alcaldes no se descubrieron ante los gobernadores tan explícitamente, pero su postura negligente dejaba entrever que tampoco intervendrían para salvaguardar los derechos de los católicos. El regidor de Carpio de Tajo (Toledo) se negó a auxiliar al cura cuando éste le pidió auxilio durante el incendio de una ermita, que quedó prácticamente destruida. Horas después, el sacerdote fue expulsado del pueblo por la misma autoridad. El teniente de alcalde de Los Corrales (Sevilla) participó en la destrucción de una cruz de hierro en una plaza del pueblo y detuvo al cura por rezar en el lugar donde había sido destruida. En Baeza (Jaén), el alcalde ordenó la retirada de un retén de guardias civiles que vigilaba una iglesia a raíz de que ésta hubiera sufrido un intento de incendio previo. El resultado de esa retirada fue que, acto continuo, la iglesia fuese asaltada y saqueada, arrojándose a un río imágenes y objetos de culto, e izándose la bandera roja en la torre. Algo parecido ocurrió en Ojén (Málaga), mientras que el alcalde de Alcoy (Alicante) no adoptó ninguna medida pese a conocer el asalto, saqueo e incendio de dos iglesias, junto al periódico «Gaceta de Levante». La fuerza pública intervino cuando, «restablecida la calma» ya se habían consumado los hechos. La complicidad o negligencia de las autoridades locales en los actos de violencia anticlerical eran tan palpables que varios alcaldes fueron destituidos o sancionados por los gobernadores, caso de los de Paterna de Rivera (Cádiz), La Zubia (Granada), Jaca (Huesca), Casarabonela (Málaga) y Catarroja (Valencia). Sin embargo, dada la extensión de los hechos, estas sanciones no constituyeron la norma. En Fuente la Higuera (Valencia) fueron los serenos los que, presenciando el asalto de la iglesia y una ermita por un grupo de socialistas, y la quema de su mobiliario frente a esos edificios, ni siquiera avisaron a la Guardia Civil. ${ }^{56}$

\footnotetext{
${ }^{55}$ ASV, Nunz. Madrid, b 945, b 925, b 912.

${ }^{56}$ AHN (Salamanca), P-S Madrid, L. 152, 1576, 2376-77 y 4550. ASV, Nunz. Madrid, b 925.
} 
Que en algunos casos protagonizaran esa violencia militantes de los partidos que sostenían en el parlamento al gobierno central o a los alcaldes en diversas localidades, podría ser una explicación del retraso y la tibieza de las actuaciones, de la sospechosa falta de detenciones, sanciones gubernativas y apertura de procesos judiciales, como no fuese contra los mismos sacerdotes, y contra otros «fascistas» o de «derechistas». Por ejemplo, en Algimia de Alfara (Valencia) se acusó a los mismos católicos de haber incendiado la iglesia parroquial. En Talavera de la Reina (Toledo) las autoridades detuvieron y encarcelaron a la directiva de Acción Católica después de que una manifestación intentara asaltar su sede. En Crevillente (Alicante) se detuvo «a unos fascistas» tras el intento de quema de una ermita, mientras que tras los incendios de nueve edificios religiosos en Villena, en la misma provincia, los guardias de Asalto apresaron a las «personas de derechas» que se habían evitado el incendio de una iglesia y un convento «mientras los incendiarios se paseaban por el pueblo tranquilamente». En Puebla del Príncipe (Ciudad Real), se prendió al cura por el incendio que destruyó totalmente la iglesia, y lo mismo ocurrió con el párroco de la iglesia de Sans, en Barcelona. ${ }^{57}$

Por otra parte, constan casos de militantes de derecha o vecinos sin significación política que fueron detenidos y encarcelados por disparar o agredir a los asaltantes de edificios religiosos. En algunas provincias, como La Coruña, se organizaron «patrullas de vigilancia» de «vecinos» para proteger las iglesias y ermitas que aún quedaban en pie en las parroquias de la capital y de El Ferrol. Incluso, en un caso, un sacerdote de Cehegín disparó contra un grupo de militantes socialistas que asaltaban una casa rectoral, matando a uno, aunque no se han podido constatar más casos en que los párrocos se defendieran recurriendo a las armas. Sin embargo, significativamente, lo que no consta en las fuentes son encarcelamientos de individuos de significación política contraria y, en concreto, de los responsables de asaltos e incendios. Más aún, lo que revelan en algunos casos es la intervención de militantes de las organizaciones obreras del Frente Popular en labores de orden público, actuando conjuntamente con la Guardia de Asalto. En Alhama de Granada (Granada) el alcalde ordenó un registro en un convento que practicaron agentes de ese cuerpo junto con miembros del centro socialista. El registro no evitó que una muchedumbre que les acompañaba lo asaltase y saquease. Las monjas hubieron de desalojarlo ante la amenaza de incendio. Los agentes también permanecieron en actitud pasiva cuando los destrozos se extendieron al cementerio. El gobernador de Cádiz confesó en un telegrama al

${ }^{57}$ ASV, Nunz. C. 925, f. 1, C. 945 y C. 912. AHN (Salamanca), P-S Madrid, L. 152, 1576 y 2377. La Vanguardia, 21-II-1936. 
ministro Amós Salvador que en San Fernando había utilizado para restablecer el orden a «elementos que están al lado del gobierno» mezclados con agentes de Asalto. El resultado fue que se apresó a dos derechistas por el incendio de la iglesia, cuando en el informe se atribuía el asalto y saqueo de la iglesia a militantes comunistas. ${ }^{58}$

En todo caso, aunque este tipo de comportamientos no pueden reputarse como la tónica general en todas las provincias, su frecuencia es indicio claro de la timidez o de la falta de respuesta de una parte sustancial de los gobernadores y, sobre todo, de sus delegados en los municipios, que eran básicamente los alcaldes. Más allá de medir el número de casos en que éstos actuaron en connivencia con los promotores de la violencia anticlerical, o simplemente adoptaron una postura negligente, conviene retener algo fundamental. Y es que el análisis general revela un comportamiento ambivalente y poliédrico por parte las autoridades ante esas agresiones que, como se ha visto, en muchos casos no eran sino una manifestación más del acoso al que fueron sometidos en numerosas localidades los derrotados en las elecciones de febrero de 1936. Este comportamiento era aún más sorprendente teniendo en cuenta que la ley de orden público vigente y los reglamentos de las distintas policías marcaban pautas y respuestas uniformes a situaciones que, como hemos visto, no hacían sino repetirse una y otra vez, y de forma prácticamente idéntica. Por tanto, la falta de respuesta uniforme derivaba de la inobservancia de estas normas, lo que motivaba que los promotores de la violencia pudieran, frecuentemente, culminar su tarea destructiva con casi impunidad. Precisamente esa inobservancia parecía responder a un cálculo de prioridades de una parte de las autoridades, determinadas antes que nada a no indisponerse con el «pueblo antifascista» en sus desahogos contra los que aún se consideraban sus «enemigos» - entre los que el clero ocupaba una posición preeminente.$-^{59}$

${ }^{58}$ ASV, Nunz. b 945. AHN (Salamanca), P-S Madrid, L. 152 y 1536.

${ }^{59}$ Ruiz, El Terror...: 38-47. 


\section{Anexo}

\section{EPISODIOS DE VIOLENCIA ANTICLERICAL (17 DE FEBRERO A 16 DE JUNIO DE 1936)}

\begin{tabular}{|c|c|c|c|c|}
\hline $\begin{array}{l}\text { Provincia y } \\
\text { Localidad }\end{array}$ & Fecha & Tipo de Violencia & Autoría & Fuente \\
\hline \multicolumn{5}{|c|}{ ÁLAVA } \\
\hline Vitoria & $24-2-36$ & $\begin{array}{l}\text { Asalto y saqueo de una iglesia. } \\
\text { Robo de los cepillos. Destrozo de } \\
\text { las imágenes. Un día después del } \\
\text { apedreamiento de un periódico } \\
\text { radical. }\end{array}$ & Desconocido & $\begin{array}{l}\text { P-S Madrid L. } \\
152 \\
\text { La Vanguardia, } \\
\text { 26-II-1936 }\end{array}$ \\
\hline $\begin{array}{l}\text { Lezama } \\
\text { (Saracho) }\end{array}$ & $15-3-36$ & $\begin{array}{l}\text { Asalto y saqueo de una iglesia. } \\
\text { Quema de imágenes y objetos de } \\
\text { culto. }\end{array}$ & Desconocido & $\begin{array}{l}\text { Nunz. C. } 945, \\
\text { F. } 3 \\
\text { P-S Madrid L. } \\
152 \\
\end{array}$ \\
\hline \begin{tabular}{|l|}
$\begin{array}{l}\text { Lezama } \\
\text { (Saracho) }\end{array}$ \\
\end{tabular} & $17-3-36$ & $\begin{array}{l}\text { Incendio de la iglesia anterior con } \\
\text { daños graves. } \\
\end{array}$ & Desconocido & \begin{tabular}{|l} 
Nunz. C. 945 \\
$D S C, 15-I V-1936$ \\
\end{tabular} \\
\hline Peñacerrada & $3-3-36$ & $\begin{array}{l}\text { Un párroco herido con arma } \\
\text { blanca. Después de una reyerta } \\
\text { entre izquierdistas y carlistas. }\end{array}$ & Desconocido & $\begin{array}{l}\text { P-S Madrid } \\
\text { L.1536 } \\
\text { Nunz. C. } 912 \\
\end{array}$ \\
\hline $\begin{array}{l}\text { Ribera Baja } \\
\text { (Ribavellosa) }\end{array}$ & $9-3-36$ & $\begin{array}{l}\text { Asalto de la iglesia. Pero } \\
\text { varios disparos hacen huir a los } \\
\text { asaltantes. }\end{array}$ & Desconocido & $\begin{array}{l}\text { P-S Madrid L. } \\
152\end{array}$ \\
\hline \multicolumn{5}{|c|}{ ALBACETE } \\
\hline Albacete & $16-3-36$ & $\begin{array}{l}\text { Dos iglesias incendiadas con } \\
\text { graves daños. Conato de incendio } \\
\text { de otra iglesia. Asalto y saqueo de } \\
\text { un convento. Quema de imágenes. } \\
\text { Tiene lugar junto al asalto y } \\
\text { destrucción de una sede de AP, tres } \\
\text { sedes sociales -una de la federación } \\
\text { de estudiantes católicos- y una } \\
\text { librería. Apedreamiento de un } \\
\text { periódico de derechas. }\end{array}$ & Desconocido & $\begin{array}{l}\text { Nunz. C. } 945, \\
\text { F. } 3 \\
\text { P-S Madrid } \\
\text { L.1536 y } 152 \\
\text { DSC }, 15-I V-1936\end{array}$ \\
\hline Almansa & $16-3-36$ & $\begin{array}{l}\text { Incendio de un convento con } \\
\text { graves daños. Se hace junto al } \\
\text { asalto y destrucción de una sede } \\
\text { de AP. }\end{array}$ & Desconocido & $\begin{array}{l}\text { Nunz. C. } 945, \\
\text { F. } 3 \\
\text { P-S Madrid } \\
\text { L.1536 y } 152 \\
\end{array}$ \\
\hline Caudete & $17-3-36$ & $\begin{array}{l}\text { Incendio de una iglesia y dos } \\
\text { ermitas con graves daños. }\end{array}$ & Desconocido & $\begin{array}{l}\text { Nunz. C. } 945, \\
\text { F. } 3 \\
\text { P-S Madrid } \\
\text { L.1536 y } 152 \\
\text { DSC }, 15-\text { IV- } 1936 \\
\end{array}$ \\
\hline $\begin{array}{l}\text { Montealegre } \\
\text { del Castillo }\end{array}$ & $4-36$ & Incendio parcial de una ermita. & Desconocido & $\begin{array}{l}\text { Nunz. C. } 925, \\
\text { F. } 1\end{array}$ \\
\hline
\end{tabular}




\begin{tabular}{|c|c|c|c|c|}
\hline $\begin{array}{l}\text { Provincia y } \\
\text { Localidad }\end{array}$ & Fecha & Tipo de Violencia & Autoría & Fuente \\
\hline Viveros & $25-4-36$ & Asalto y saqueo de la casa rectoral. & Desconocido & ADT, Secretaría \\
\hline \multicolumn{5}{|c|}{ ALICANTE } \\
\hline Alicante & $20-2-36$ & \begin{tabular}{|l|} 
Incendio de tres iglesias, una \\
casa rectoral, un asilo y una \\
colegiata con graves daños. \\
Asalto y saqueo de otra iglesia. \\
Quema de imágenes. Tiene lugar \\
junto al incendio o asalto de seis \\
sedes y dos periódicos de centro \\
y derecha, el reformatorio de \\
adultos, la Cámara de la Propiedad \\
y varios domicilios particulares. \\
\end{tabular} & Desconocido & $\begin{array}{l}\text { Nunz. C. } 945 \\
\text { F. } 3 \\
\text { P-S Madrid L. } \\
152 \text { y } 1536\end{array}$ \\
\hline Alicante & $25-2-36$ & $\begin{array}{l}\text { Incendio de dos ermitas con } \\
\text { graves daños. }\end{array}$ & Desconocido & Nunz. C. 945 \\
\hline Alcoy & $20-2-36$ & $\begin{array}{l}\text { Incendio parcial de una iglesia. } \\
\text { Tiene lugar junto con un } \\
\text { periódico de derecha. }\end{array}$ & Desconocido & $\begin{array}{l}\text { Nunz. C. } 945, \text { F. } \\
3 \text { y } 912 \\
\text { P-S Madrid } \\
\text { L.1536 }\end{array}$ \\
\hline Alcoy & $31-3-36$ & \begin{tabular}{|l|} 
Incendio de una iglesia con \\
graves daños. Asalto y saqueo de \\
otra iglesia. Quema de imágenes \\
y objetos de culto. Nuevo asalto y \\
destrozo a un periódico.
\end{tabular} & Desconocido & $\begin{array}{l}\text { Nunz. C. } 945, \text { F. } \\
\text { 3; y C. 925, F. } 1 \\
\text { P-S Madrid L. } \\
152 \\
\text { DSC, 7-V-1936 }\end{array}$ \\
\hline Almoradí & $1-5-36$ & $\begin{array}{l}\text { Asalto y ocupación de la casa } \\
\text { rectoral. }\end{array}$ & Socialistas & $\begin{array}{l}\text { Nunz. C. 925, } \\
\text { F. } 1 \\
\text { P-S Madrid L. } \\
2376\end{array}$ \\
\hline Altea & $8-3-36$ & $\begin{array}{l}\text { Después de misa, un grupo tirotea } \\
\text { al vicario sin consecuencias. }\end{array}$ & Desconocido & $\begin{array}{l}\text { Nunz. C. } 967, \\
\text { F. } 1\end{array}$ \\
\hline Altea & $1-5-36$ & $\begin{array}{l}\text { Incendio de una iglesia con } \\
\text { graves daños. }\end{array}$ & Desconocido & $\begin{array}{l}\text { Nunz. C. 925, } \\
\text { F. } 1\end{array}$ \\
\hline Aspe & $29-3-36$ & $\begin{array}{l}\text { Asalto y saqueo de una ermita. } \\
\text { Destrozo de imágenes y objetos } \\
\text { de culto. }\end{array}$ & Desconocido & $\begin{array}{l}\text { P-S Madrid L. } \\
152 \\
\text { La Vanguardia, } \\
31-\text { III-1936 }\end{array}$ \\
\hline Benejama & $23-3-36$ & $\begin{array}{l}\text { Conato de incendio en una iglesia, } \\
\text { la casa rectoral y un convento. }\end{array}$ & Desconocido & \begin{tabular}{|l|} 
Nunz. C. 945, \\
F. 3
\end{tabular} \\
\hline Benilloba & $21-2-36$ & Conato de incendio en la iglesia & Desconocido & $\begin{array}{l}\text { P-S Madrid } \\
\text { L.1536 }\end{array}$ \\
\hline Benilloba & $6-3-36$ & Conato de incendio en la iglesia & Desconocido & $\begin{array}{l}\text { Nunz. C. } 945, \\
\text { F. } 3\end{array}$ \\
\hline Busot & $1-5-36$ & $\begin{array}{l}\text { Asalto y saqueo de la } \\
\text { iglesia. Destrozo de una cruz } \\
\text { monumental. }\end{array}$ & Desconocido & $\begin{array}{l}\text { Nunz. C. } 925, \\
\text { F. } 1 \\
\text { DSC, } 7-\mathrm{V}-1936\end{array}$ \\
\hline
\end{tabular}

Hispania Sacra, LXV

132, julio-diciembre 2013, 683-764, ISSN: 0018-215X, doi: 10.3989/hs.2013.033 


\begin{tabular}{|c|c|c|c|c|}
\hline $\begin{array}{l}\text { Provincia y } \\
\text { Localidad }\end{array}$ & Fecha & Tipo de Violencia & Autoría & Fuente \\
\hline Catral & $20-4-36$ & $\begin{array}{l}\text { Incendio de una iglesia con } \\
\text { graves daños. }\end{array}$ & Desconocido & $\begin{array}{l}\text { Nunz. C. } 925, \\
\text { F. } 1\end{array}$ \\
\hline Crevillente & $\begin{array}{c}16 y \\
17-3-36\end{array}$ & $\begin{array}{l}\text { Incendio de una iglesia con } \\
\text { graves daños. Conato de incendio } \\
\text { de una ermita. }\end{array}$ & Desconocido & $\begin{array}{l}\text { Nunz. C. } 945, \\
\text { F. } 3 \\
\text { P-S Madrid } \\
\text { L.1536 y } 152 \\
\end{array}$ \\
\hline Crevillente & $22-4-36$ & $\begin{array}{l}\text { Incendio de una iglesia con } \\
\text { graves daños. }\end{array}$ & Desconocido & $\begin{array}{l}\text { Nunz. C. } 925, \\
\text { F. } 1\end{array}$ \\
\hline El Altet & $20-2-36$ & $\begin{array}{l}\text { Incendio de una iglesia con } \\
\text { graves daños. }\end{array}$ & Desconocido & $\begin{array}{l}\text { Nunz. C. } 945, \\
\text { F. } 3\end{array}$ \\
\hline Elche & $20-2-36$ & $\begin{array}{l}\text { Incendio de cuatro iglesias y } \\
\text { un convento con daños graves. } \\
\text { Asalto y saqueo de un centro de } \\
\text { Acción Católica. Tiene lugar junto } \\
\text { al asalto y saqueo de la sede de } \\
\text { los sindicatos católicos, cuatro } \\
\text { sedes de derecha, el Juzgado y la } \\
\text { Cámara de la Propiedad, dos sedes } \\
\text { sociales y un domicilio particular. }\end{array}$ & Desconocido & $\begin{array}{l}\text { Nunz. C. } 945, \\
\text { F. } 3 \\
\text { P-S Madrid L. } \\
152 \text { y } 1536 \\
D S C, 5-V-1936\end{array}$ \\
\hline Elche & $19-5-36$ & Asalto de una casa rectoral. & Desconocido & $\begin{array}{l}\text { Nunz. C. } 925, \\
\text { F. } 1\end{array}$ \\
\hline Elda & $20-3-36$ & Incendio parcial de una iglesia. & Desconocido & $\begin{array}{l}\text { P-S Madrid L. } \\
152 \\
\end{array}$ \\
\hline Elda & $23-3-36$ & $\begin{array}{l}\text { Conato de incendio en una } \\
\text { iglesia. Tiene lugar junto al } \\
\text { incendio de una fábrica y un } \\
\text { domicilio particular }\end{array}$ & Desconocido & Nunz. C. 945 \\
\hline La Alcoraya & $26-3-36$ & Asalto y saqueo de la iglesia. & Desconocido & \begin{tabular}{|l|} 
Nunz. C. 925, \\
F. 1 \\
\end{tabular} \\
\hline La Nucia & $20-2-36$ & $\begin{array}{l}\text { Incendio de la iglesia con graves } \\
\text { daños. Quema de imágenes y } \\
\text { confesionario }\end{array}$ & Desconocido & $\begin{array}{l}\text { Nunz. C. } 945 \\
\text { F. } 3 \\
\text { P-S Madrid L. } \\
152\end{array}$ \\
\hline La Romana & $21-2-36$ & $\begin{array}{l}\text { Asalto y saqueo de la iglesia. } \\
\text { Quema de objetos de culto. }\end{array}$ & Desconocido & $\begin{array}{l}\text { P-S Madrid } \\
\text { L.1536 } \\
\end{array}$ \\
\hline $\begin{array}{l}\text { Los } \\
\text { Montesinos }\end{array}$ & $4-3-36$ & $\begin{array}{l}\text { Incendio de la iglesia con graves } \\
\text { daños. }\end{array}$ & Desconocido & $\begin{array}{l}\text { Nunz. C. } 945, \\
\text { F. } 3\end{array}$ \\
\hline $\begin{array}{l}\text { Monforte del } \\
\text { Cid }\end{array}$ & $15-3-36$ & $\begin{array}{l}\text { Incendio de una ermita con } \\
\text { graves daños. }\end{array}$ & Desconocido & $\begin{array}{l}\text { Nunz. C. } 945, \\
\text { F. } 3 \\
\text { P-S Madrid L. } \\
152\end{array}$ \\
\hline \begin{tabular}{|l|} 
Monforte del \\
Cid (Orito)
\end{tabular} & $21-2-36$ & $\begin{array}{l}\text { Incendio parcial de un convento. } \\
\text { Quema de varios objetos de culto. }\end{array}$ & Desconocido & $\begin{array}{l}\text { P-S Madrid } \\
\text { L.1536 }\end{array}$ \\
\hline
\end{tabular}




\begin{tabular}{|c|c|c|c|c|}
\hline $\begin{array}{l}\text { Provincia y } \\
\text { Localidad }\end{array}$ & Fecha & Tipo de Violencia & Autoría & Fuente \\
\hline $\begin{array}{l}\text { Monóvar } \\
\text { (Casas del } \\
\text { Señor) }\end{array}$ & $3-36$ & $\begin{array}{l}\text { Estalla una bomba en la casa } \\
\text { rectoral. }\end{array}$ & Desconocido & $\begin{array}{l}\text { Nunz. C. } 945 \\
\text { F. } 3\end{array}$ \\
\hline Novelda & $20-2-36$ & $\begin{array}{l}\text { Asalto y saqueo de un centro } \\
\text { de Acción Católica. Conato de } \\
\text { incendio en un convento. Tiene } \\
\text { lugar junto al destrozo de la sede } \\
\text { de los sindicatos católicos. } \\
\end{array}$ & Desconocido & $\begin{array}{l}\text { Nunz. C. } 945, \\
\text { F. } 3 \\
\text { P-S Madrid } \\
\text { L.1536 }\end{array}$ \\
\hline Orcheta & $26-5-36$ & Incendio parcial de la iglesia. & Desconocido & $\begin{array}{l}\text { Nunz. C. } 925, \\
\text { F. } 1\end{array}$ \\
\hline Relleu & $19-2-36$ & $\begin{array}{l}\text { Incendio de la iglesia y una } \\
\text { ermita con graves daños. Quema } \\
\text { de imágenes y objetos de culto. }\end{array}$ & Desconocido & $\begin{array}{l}\text { Nunz. C. } 945, \\
\text { F. } 3 \\
\text { P-S Madrid L. } \\
152 \\
\end{array}$ \\
\hline $\begin{array}{l}\text { San Miguel } \\
\text { de Salinas }\end{array}$ & $1-5-36$ & $\begin{array}{l}\text { Incendio de la iglesia con graves } \\
\text { daños. Destrozo de imágenes y } \\
\text { objetos de culto. }\end{array}$ & Desconocido & $\begin{array}{l}\text { Nunz. C. } 925, \\
\text { F. } 1 \\
\text { P-S Madrid L. } \\
2376 \\
\text { DSC, } 7-\mathrm{V}-1936 \\
\end{array}$ \\
\hline Sax & $25-3-36$ & Incendio parcial de dos ermitas. & Desconocido & $\begin{array}{l}\text { P-S Madrid } \\
\text { L.1536 y } 152 \\
\end{array}$ \\
\hline Sax & 24-4-36 & $\begin{array}{l}\text { Incendio de "todas" las ermitas } \\
\text { con graves daños (al menos dos). }\end{array}$ & Desconocido & $\begin{array}{l}\text { Nunz. C. } 925, \\
\text { F. } 1\end{array}$ \\
\hline Sella & $17-2-36$ & $\begin{array}{l}\text { Asalto a la casa rectoral. El cura } \\
\text { ha de escapar para no ser linchado. }\end{array}$ & Desconocido & $\begin{array}{l}\text { Nunz. C. } 945, \\
\text { F. } 3\end{array}$ \\
\hline Sella & $1-5-36$ & $\begin{array}{l}\text { Incendio de la iglesia y una } \\
\text { ermita con graves daños. }\end{array}$ & Desconocido & $\begin{array}{l}\text { Nunz. C. } 925, \\
\text { F. } 1 \\
\text { DSC, 7-V-1936 } \\
\end{array}$ \\
\hline Tangel & $20-2-36$ & $\begin{array}{l}\text { Incendio de la iglesia con graves } \\
\text { daños. }\end{array}$ & Desconocido & \begin{tabular}{|l} 
Nunz. C. 945, \\
F. 3
\end{tabular} \\
\hline Torrevieja & $\begin{array}{c}3 y \\
4-3-36\end{array}$ & \begin{tabular}{|l|} 
Incendio de una iglesia y una \\
ermita con graves daños. Conato \\
de incendio de otra iglesia. Tiene \\
lugar junto al asalto y destrucción \\
del Archivo Municipal, el \\
Registro de la Propiedad, la \\
sede del Partido Radical y dos \\
domicilios particulares.
\end{tabular} & Desconocido & $\begin{array}{l}\text { Nunz. C. } 945, \text { F. } \\
3 \text { y } 912 \\
\text { P-S Madrid } \\
\text { L.1536 y } 152 \\
D S C, 15-I V-1936 .\end{array}$ \\
\hline $\begin{array}{l}\text { Villafran- } \\
\text { queza }\end{array}$ & $20-2-36$ & $\begin{array}{l}\text { Incendio de la iglesia con graves } \\
\text { daños. }\end{array}$ & Desconocido & \begin{tabular}{|l} 
Nunz. C. 945, \\
F. 3
\end{tabular} \\
\hline
\end{tabular}




\begin{tabular}{|c|c|c|c|c|}
\hline $\begin{array}{l}\text { Provincia y } \\
\text { Localidad }\end{array}$ & Fecha & Tipo de Violencia & Autoría & Fuente \\
\hline Villena & $14-3-36$ & $\begin{array}{l}\text { Incendio parcial de una iglesia, } \\
\text { una casa rectoral y un convento. } \\
\text { Incendio de un colegio y cinco } \\
\text { ermitas con graves daños. Quema } \\
\text { de objetos de culto. }\end{array}$ & Desconocido & $\begin{array}{l}\text { Nunz. C. } 945 \text {, } \\
\text { F. } 3 \\
\text { P-S Madrid } \\
\text { L.1536 y } 152\end{array}$ \\
\hline $\begin{array}{l}\text { Villena } \\
\text { (La Encina) }\end{array}$ & $17-3-36$ & $\begin{array}{l}\text { Incendio de la iglesia y la casa } \\
\text { rectoral con graves daños. }\end{array}$ & Desconocido & $\begin{array}{l}\text { Nunz. C. } 945, \\
\text { F. } 3 \\
\text { P-S Madrid L. } \\
152 \\
\text { DSC, } 15-I V-1936\end{array}$ \\
\hline Villena & $16-4-36$ & $\begin{array}{l}\text { Incendio parcial de una ermita, } \\
\text { de un convento y de un hospital } \\
\text { religioso. }\end{array}$ & Desconocido & $\begin{array}{l}\text { Nunz. C. } 925, \\
\text { F. } 1\end{array}$ \\
\hline Villena & $25-5-36$ & $\begin{array}{l}\text { Incendio parcial de una iglesia y } \\
\text { un convento. }\end{array}$ & Desconocido & $A B C, 27-\mathrm{V}-36$ \\
\hline \multicolumn{5}{|c|}{ ALMERÍA } \\
\hline Almería & $\begin{array}{c}20 y \\
21-2-36\end{array}$ & $\begin{array}{l}\text { Conato de incendio en cuatro } \\
\text { iglesias y un convento. }\end{array}$ & Desconocido & $\begin{array}{l}\text { Nunz. C. } 945, \\
\text { F. } 3 \\
\text { P-S Madrid } \\
\text { L.1536 y } 152\end{array}$ \\
\hline Adra & $4-36$ & $\begin{array}{l}\text { Asalto y saqueo de tres ermitas. } \\
\text { Robo de objetos de culto. }\end{array}$ & Desconocido & $\begin{array}{l}\text { Nunz. C. } 925, \\
\text { F. } 1\end{array}$ \\
\hline Gádor & $16-3-36$ & $\begin{array}{l}\text { Asalto y saqueo de la iglesia. } \\
\text { Quema de imágenes. }\end{array}$ & Desconocido & $\begin{array}{l}\text { Nunz. C. } 945, \\
\text { F. } 3 \\
\text { P-S Madrid } \\
\text { L.1536 }\end{array}$ \\
\hline \multicolumn{5}{|c|}{ ÁVILA } \\
\hline Ávila & $25-2-36$ & Incendio parcial de una iglesia. & Desconocido & $\begin{array}{l}\text { La Vanguardia, } \\
\text { 26-II-1936 }\end{array}$ \\
\hline Ávila & $5-3-36$ & Incendio parcial de un convento. & Desconocido & $\begin{array}{l}\text { P-S Madrid } \\
\text { L.1536 }\end{array}$ \\
\hline Ávila & $22-3-36$ & $\begin{array}{l}\text { Conato de incendio en un } \\
\text { convento. }\end{array}$ & Desconocido & $\begin{array}{l}\text { Nunz. C. } 945, \\
\text { F. } 3 \\
\text { P-S Madrid } \\
\text { L.1536 }\end{array}$ \\
\hline Arévalo & $3-36$ & $\begin{array}{l}\text { Asalto y ocupación de una } \\
\text { iglesia. Derribo de una cruz } \\
\text { monumental. }\end{array}$ & Socialistas & $\begin{array}{l}\text { Nunz. C. } 925, \\
\text { F. } 1\end{array}$ \\
\hline Arévalo & $1-5-36$ & $\begin{array}{l}\text { Asalto y ocupación de una } \\
\text { iglesia. }\end{array}$ & $\begin{array}{l}\text { Manifestantes } \\
1^{\circ} \text { Mayo }\end{array}$ & $\begin{array}{l}\text { P-S Madrid L. } \\
2377\end{array}$ \\
\hline El Hornillo & $3-36$ & $\begin{array}{l}\text { Asalto de la iglesia y robo de los } \\
\text { badajos de las campanas. }\end{array}$ & Desconocido & $\begin{array}{l}\text { Nunz. C. } 925, \\
\text { F. } 1\end{array}$ \\
\hline
\end{tabular}




\begin{tabular}{|c|c|c|c|c|}
\hline $\begin{array}{l}\text { Provincia y } \\
\text { Localidad }\end{array}$ & Fecha & Tipo de Violencia & Autoría & Fuente \\
\hline $\begin{array}{l}\text { Navalperal de } \\
\text { Pinares }\end{array}$ & $3-36$ & $\begin{array}{l}\text { Asalto y destrozos en el } \\
\text { cementerio. }\end{array}$ & Desconocido & $\begin{array}{l}\text { Nunz. C. } 945, \\
\text { F. } 3\end{array}$ \\
\hline $\begin{array}{l}\text { Pedro } \\
\text { Bernardo }\end{array}$ & $3-36$ & Derribo de una cruz monumental. & Desconocido & $\begin{array}{l}\text { Nunz. C. } 925, \\
\text { F. } 1\end{array}$ \\
\hline Piedralaves & $4-36$ & $\begin{array}{l}\text { Derribo de varias cruces } \\
\text { (al menos dos). }\end{array}$ & Desconocido & $\begin{array}{l}\text { Nunz. C. } 925, \\
\text { F. } 1\end{array}$ \\
\hline \multicolumn{5}{|c|}{ BADAJOZ } \\
\hline Alburquerque & $20-3-36$ & $\begin{array}{l}\text { Asalto a una iglesia. } \\
\text { Desplazamiento de imágenes. }\end{array}$ & Desconocido & $\begin{array}{l}\text { Nunz. C. 945, } \\
\text { F. } 3 \\
\text { P-S Madrid L. } \\
1536 \\
\end{array}$ \\
\hline Almendralejo & $1-5-36$ & \begin{tabular}{|l|} 
Asalto y saqueo de un convento. \\
Conato de incendio en una iglesia. \\
\end{tabular} & Desconocido & \begin{tabular}{|l} 
Nunz. C. 925, \\
F. 1
\end{tabular} \\
\hline Bienvenida & $4-36$ & Incendio parcial de la iglesia. & Desconocido & \begin{tabular}{|l} 
Nunz. C. 925, \\
F. 1
\end{tabular} \\
\hline Don Benito & $3-36$ & $\begin{array}{l}\text { Conato de incendio en una } \\
\text { iglesia. }\end{array}$ & Desconocido & $\begin{array}{l}\text { Nunz. C. } 945, \\
\text { F. } 3\end{array}$ \\
\hline $\begin{array}{l}\text { Jerez de los } \\
\text { Caballeros }\end{array}$ & $8-3-36$ & \begin{tabular}{|l|} 
Asalto y saqueo de una iglesia. \\
Destrozo de mobiliario e imágenes. \\
Tiene lugar junto al apedreamiento \\
de varios domicilios particulares y \\
conatos de asalto a sedes de derecha.
\end{tabular} & Desconocido & $\begin{array}{l}\text { Nunz. C. } 945, \\
\text { F. } 3 \\
\text { P-S Madrid L. } \\
152\end{array}$ \\
\hline Zafra & $\begin{array}{c}4 y \\
5-5-36\end{array}$ & $\begin{array}{l}\text { Asalto a un colegio religioso. } \\
\text { Golpean a dos frailes en el momento } \\
\text { en que desalojaban sus casas. }\end{array}$ & Desconocido & $\begin{array}{l}\text { Nunz. C. } 925, \text { F. } \\
1 \text { y } 945\end{array}$ \\
\hline \multicolumn{5}{|c|}{ BALEARES } \\
\hline $\begin{array}{l}\text { Palma de } \\
\text { Mallorca }\end{array}$ & $5-6-36$ & $\begin{array}{l}\text { Asalto y saqueo de una iglesia. } \\
\text { Destrozo de mobiliario y objetos } \\
\text { de culto. Incendio parcial de otra } \\
\text { iglesia. Conatos de incendio en } \\
\text { dos iglesias más. Estalla una } \\
\text { bomba en una de ellas. }\end{array}$ & Desconocido & $\begin{array}{l}\text { Nunz. C. } 925, \\
\text { F. } 1 \\
\text { La Vanguardia, } 7 \\
\text { y 12-VI-1936 }\end{array}$ \\
\hline Benisalem & $5-36$ & $\begin{array}{l}\text { Agresión a un sacerdote, que es } \\
\text { también desnudado y robado. }\end{array}$ & Desconocido & \begin{tabular}{|l} 
Nunz. C. 925, \\
F. 1
\end{tabular} \\
\hline $\begin{array}{l}\text { Campos del } \\
\text { Puerto }\end{array}$ & $23-3-36$ & $\begin{array}{l}\text { Conato de incendio de una } \\
\text { iglesia. }\end{array}$ & Desconocido & $\begin{array}{l}\text { Nunz. C. } 945, \\
\text { F. } 3 \\
\text { La Vanguardia, } \\
\text { 25-III-1936 }\end{array}$ \\
\hline San Carlos & $23-3-36$ & Incendio parcial de una iglesia. & Desconocido & $\begin{array}{l}\text { La Vanguardia, } \\
\text { 26-III-1936 }\end{array}$ \\
\hline $\begin{array}{l}\text { San } \\
\text { Fernando de } \\
\text { Formentera }\end{array}$ & $5-36$ & $\begin{array}{l}\text { Asalto y saqueo de la iglesia. } \\
\text { Robo de objetos de culto. }\end{array}$ & Desconocido & $\begin{array}{l}\text { Nunz. C. } 925, \\
\text { F. } 1\end{array}$ \\
\hline
\end{tabular}




\begin{tabular}{|c|c|c|c|c|}
\hline $\begin{array}{l}\text { Provincia y } \\
\text { Localidad }\end{array}$ & Fecha & Tipo de Violencia & Autoría & Fuente \\
\hline \multicolumn{5}{|c|}{ BARCELONA } \\
\hline Barcelona & $20-2-36$ & Incendio parcial de una iglesia. & Desconocido & $\begin{array}{l}\text { Nunz. C. } 945, \\
\text { F. } 3 \\
\text { P-S Madrid L. } \\
152 \\
\end{array}$ \\
\hline Barcelona & $14-4-36$ & \begin{tabular}{|l|}
$\begin{array}{l}\text { Derribo de tres cruces } \\
\text { monumentales. }\end{array}$ \\
\end{tabular} & \begin{tabular}{|c|} 
Militantes de \\
ERC \\
\end{tabular} & \begin{tabular}{|l} 
P-S Madrid L. \\
152 \\
\end{tabular} \\
\hline Badalona & $5-36$ & $\begin{array}{l}\text { Incendio de una ermita con } \\
\text { graves daños. }\end{array}$ & Desconocido & $\begin{array}{l}\text { Nunz. C. 925, } \\
\text { F. } 1 \\
\end{array}$ \\
\hline Manresa & $3-36$ & $\begin{array}{l}\text { Asalto y destrozos en un } \\
\text { cementerio. }\end{array}$ & Desconocido & \begin{tabular}{|l} 
Nunz. C. 945, \\
F. 3
\end{tabular} \\
\hline Sampedor & $5-36$ & Incendio parcial de una ermita. & Desconocido & Nunz. C. 925 , F. 1 \\
\hline \multicolumn{5}{|c|}{ BURGOS } \\
\hline $\begin{array}{l}\text { Busto de } \\
\text { Bureba }\end{array}$ & $23-2-36$ & $\begin{array}{l}\text { Asalto y saqueo de la iglesia. } \\
\text { Destrozo de imágenes. Robo de } \\
\text { objetos de culto. }\end{array}$ & Desconocido & $\begin{array}{l}\text { P-S Madrid L. } \\
152 \\
\text { Nunz. C. } 912 \\
\text { DSC, } 15-I V-1936 \\
\end{array}$ \\
\hline Castrojeriz & $20-2-36$ & \begin{tabular}{|l} 
Derribo de dos cruces \\
monumentales. Tienen lugar \\
junto a las placas del juzgado y \\
del registro de la propiedad. \\
\end{tabular} & \begin{tabular}{|} 
Manifestación \\
Frente \\
Popular
\end{tabular} & $\begin{array}{l}\text { P-S Madrid } \\
\text { L.1536 }\end{array}$ \\
\hline Fuentemolino & $3-36$ & Conato de incendio en la iglesia. & Desconocido & \begin{tabular}{|l|} 
Nunz. C. 945, \\
F. 3 \\
\end{tabular} \\
\hline $\begin{array}{l}\text { Gamonal de } \\
\text { Río Pico }\end{array}$ & $23-2-36$ & $\begin{array}{l}\text { Asalto y saqueo de la iglesia. } \\
\text { Destrozo de las imágenes. }\end{array}$ & Desconocido & \begin{tabular}{|l|} 
P-S Madrid L. \\
152 \\
Nunz. C. 912 \\
DSC, $15-$ IV-1936 \\
\end{tabular} \\
\hline $\begin{array}{l}\text { Miranda de } \\
\text { Ebro }\end{array}$ & $24-5-36$ & $\begin{array}{l}\text { Incendio de una iglesia y una casa } \\
\text { rectoral con graves daños. }\end{array}$ & Desconocido & $\begin{array}{l}\text { Nunz. C. } 925, \\
\text { F. } 1 \\
\text { AGA Serie } \\
\text { 008/44/C. } 2790 \\
\end{array}$ \\
\hline Tardajos & $23-2-36$ & $\begin{array}{l}\text { Asalto y saqueo de la iglesia. } \\
\text { Robo de objetos de culto. }\end{array}$ & Desconocido & $\begin{array}{l}\text { P-S Madrid L. } 152 \\
\text { Nunz. C. } 912 \\
\text { DSC, 15-IV-1936 } \\
\end{array}$ \\
\hline Villaldemiro & $22-4-36$ & $\begin{array}{l}\text { Asalto y saqueo de la iglesia. } \\
\text { Robo de objetos de culto }\end{array}$ & Desconocido & $\begin{array}{l}\text { La Vanguardia, } \\
\text { 24-IV-1936 } \\
\end{array}$ \\
\hline \begin{tabular}{|l|} 
Villanueva de \\
Gumiel \\
\end{tabular} & $11-5-36$ & $\begin{array}{l}\text { Asalto y saqueo de una ermita. } \\
\text { Destrozo de una imagen. }\end{array}$ & Desconocido & \begin{tabular}{|l|} 
Nunz. C. 925, \\
F. 1 \\
\end{tabular} \\
\hline $\begin{array}{l}\text { Villanueva de } \\
\text { las Carretas }\end{array}$ & $22-4-36$ & $\begin{array}{l}\text { Asalto y saqueo de la iglesia. } \\
\text { Robo de objetos de culto. }\end{array}$ & Desconocido & $\begin{array}{l}\text { La Vanguardia, } \\
\text { 24-IV-1936 } \\
\end{array}$ \\
\hline
\end{tabular}




\begin{tabular}{|c|c|c|c|c|}
\hline $\begin{array}{l}\text { Provincia y } \\
\text { Localidad }\end{array}$ & Fecha & Tipo de Violencia & Autoría & Fuente \\
\hline \multicolumn{5}{|c|}{ CÁCERES } \\
\hline Cedillo & $4-36$ & Derribo de una cruz monumental. & Desconocido & $\begin{array}{l}\text { Nunz. C. } 925, \\
\text { F. } 1\end{array}$ \\
\hline Hervás & $29-3-36$ & $\begin{array}{l}\text { Incendio parcial de una iglesia. } \\
\text { Robo de objetos de culto. }\end{array}$ & Desconocido & $\begin{array}{l}\text { Nunz. C. } 945, \\
\text { F. } 3 \\
\text { P-S Madrid } \\
\text { L.1536 y } 152\end{array}$ \\
\hline $\begin{array}{l}\text { San Vicente } \\
\text { de Alcántara }\end{array}$ & $4-36$ & $\begin{array}{l}\text { Derribo de tres cruces } \\
\text { monumentales. }\end{array}$ & Desconocido & $\begin{array}{l}\text { Nunz. C. } 925, \\
\text { F. } 1\end{array}$ \\
\hline \multicolumn{5}{|c|}{ CÁDIZ } \\
\hline Cádiz & $8-3-36$ & $\begin{array}{l}\text { Incendio de la Curia, ocho } \\
\text { iglesias, cuatro conventos y tres } \\
\text { colegios, con daños de gravedad. } \\
\text { Quema de imágenes y objetos de } \\
\text { culto. Asalto de cuatro conventos } \\
\text { más. Tiene lugar junto al asalto } \\
\text { del sindicato católico y del } \\
\text { recinto del consulado alemán }\end{array}$ & Desconocido & $\begin{array}{l}\text { Nunz. C. } 945, \\
\text { F. } 3 \\
\text { P-S Madrid } \\
\text { L.1536 y } 152 \\
\text { DSC }, 15-\mathrm{IV}-1936\end{array}$ \\
\hline Algar & $19-4-36$ & $\begin{array}{l}\text { Asalto y saqueo de una iglesia. } \\
\text { Quema de imágenes y objetos de } \\
\text { culto. }\end{array}$ & Desconocido & $\begin{array}{l}\text { Nunz. C. 925, F. } 1 \\
\text { P-S Madrid L. } \\
2376\end{array}$ \\
\hline Algar & $3-5-36$ & $\begin{array}{l}\text { Asalto de la casa rectoral y } \\
\text { expulsión del párroco. }\end{array}$ & Desconocido & DSC, 7-V-1936 \\
\hline Benaocaz & $9-4-36$ & $\begin{array}{l}\text { Asalto y saqueo de la iglesia y } \\
\text { de varias ermitas (al menos dos). } \\
\text { Destrozo del mobiliario. }\end{array}$ & Desconocido & $\begin{array}{l}\text { Nunz. C. } 925, \\
\text { F. } 1\end{array}$ \\
\hline Ceuta & $1-3-36$ & $\begin{array}{l}\text { Incendio parcial de una iglesia. } \\
\text { Tiene lugar junto al asalto de las } \\
\text { sedes de AP y su sección femenina. }\end{array}$ & Desconocido & $\begin{array}{l}\text { P-S Madrid } \\
\text { L.1536 }\end{array}$ \\
\hline Ceuta & $\begin{array}{c}20 \text { y } 21 \\
4-36\end{array}$ & $\begin{array}{l}\text { Asalto y ocupación de un } \\
\text { convento y una iglesia. }\end{array}$ & $\begin{array}{l}\text { Obreros del } \\
\text { Fr. Popular }\end{array}$ & \begin{tabular}{|l|} 
P-S Madrid L. \\
2377 \\
P-S Madrid 4550 \\
\end{tabular} \\
\hline El Gastor & $3-5-36$ & Asalto y saqueo de la iglesia. & Desconocido & $\begin{array}{l}\text { Nunz. C. } 925, \\
\text { F. } 1 \\
\text { DSC, 7-V-1936 } \\
\end{array}$ \\
\hline El Mimbral & $19-4-36$ & $\begin{array}{l}\text { Asalto y saqueo de una ermita. } \\
\text { Quema de imágenes y objetos de } \\
\text { culto. }\end{array}$ & Desconocido & $\begin{array}{l}\text { P-S Madrid L. } \\
2376\end{array}$ \\
\hline Grazalema & $20-4-36$ & $\begin{array}{l}\text { Incendio de dos iglesias con } \\
\text { graves daños. Asalto y saqueo } \\
\text { de otra. Quema de imágenes y } \\
\text { objetos de culto. }\end{array}$ & Desconocido & $\begin{array}{l}\text { Nunz. C. } 925, \\
\text { F. } 1 \\
\text { P-S Madrid L. } \\
2377 \\
D S C, 7-V-1936 \\
\end{array}$ \\
\hline
\end{tabular}




\begin{tabular}{|c|c|c|c|c|}
\hline $\begin{array}{l}\text { Provincia y } \\
\text { Localidad }\end{array}$ & Fecha & Tipo de Violencia & Autoría & Fuente \\
\hline \begin{tabular}{|l|} 
Grazalema \\
Benamahoma \\
\end{tabular} & $15-5-36$ & $\begin{array}{l}\text { Asalto y saqueo de una iglesia. } \\
\text { Destrozo de mobiliario. }\end{array}$ & Desconocido & $\begin{array}{l}\text { Nunz. C. } 925, \\
\text { F. } 1\end{array}$ \\
\hline $\begin{array}{l}\text { Jerez de la } \\
\text { Frontera }\end{array}$ & $14-4-36$ & $\begin{array}{l}\text { Asalto y saqueo de cinco } \\
\text { conventos. Destrozo del mobiliario. } \\
\text { Tiene lugar junto al de dos } \\
\text { periódicos de derecha y las sedes } \\
\text { de Se hace lo mismo con dos } \\
\text { periódicos y las sedes de AP y FE. } \\
\end{array}$ & Desconocido & $\begin{array}{l}\text { Nunz. C. } 925, \\
\text { F. } 1 \\
\text { P-S Madrid L. } \\
152 \\
D S C, 7-V-1936\end{array}$ \\
\hline $\begin{array}{l}\text { Jerez de la } \\
\text { Frontera }\end{array}$ & $12-5-36$ & $\begin{array}{l}\text { Asalto y saqueo de una iglesia. } \\
\text { Robo del mobiliario. }\end{array}$ & Desconocido & $A B C, 12-\mathrm{V}-1936$ \\
\hline $\begin{array}{l}\text { Los Barrios } \\
\text { (Palmones) }\end{array}$ & $8-3-36$ & $\begin{array}{l}\text { Asalto y saqueo de la iglesia. } \\
\text { Destrozo de las imágenes. }\end{array}$ & Desconocido & $\begin{array}{l}\text { Nunz. C. 945, F. } 3 \\
\text { P-S Madrid } \\
\text { L.1536 } \\
\end{array}$ \\
\hline $\begin{array}{l}\text { Paterna de } \\
\text { Rivera }\end{array}$ & $24-4-36$ & $\begin{array}{l}\text { Incendio parcial de la iglesia. } \\
\text { Destrozo de imágenes. }\end{array}$ & Desconocido & $\begin{array}{l}\text { Nunz. C. 925, F. } 1 \\
\text { P-S Madrid L. } \\
2377 \\
\end{array}$ \\
\hline Prado del Rey & $25-3-36$ & $\begin{array}{l}\text { Asalto y ocupación de una } \\
\text { iglesia. }\end{array}$ & Socialistas & $\begin{array}{l}\text { Nunz. C. 925, F. } 1 \\
\text { P-S Madrid } \\
\text { L.1536 } \\
\end{array}$ \\
\hline $\begin{array}{l}\text { Puerto de } \\
\text { Santa María }\end{array}$ & $\begin{array}{c}16 y \\
17-4-36\end{array}$ & \begin{tabular}{|l|} 
Incendio a un centro de Acción \\
Católica con graves daños. Conato \\
de asalto a una iglesia. Tiene lugar \\
junto al incendio de un bar, dos \\
fábricas, una tienda, un domicilio, \\
un periódico de derecha, y al \\
asalto a un centro de AP, en el que \\
se quemaron enseres. Destrozos \\
en puertas y ventanas de varios \\
domicilios particulares.
\end{tabular} & Desconocido & $\begin{array}{l}\text { P-S Madrid L. } \\
2377 \\
\text { DSC, } 18-\mathrm{IV} \text { y } \\
11-\mathrm{VI}-1936\end{array}$ \\
\hline Puerto Real & $8-3-36$ & $\begin{array}{l}\text { Asalto y saqueo de dos iglesias. } \\
\text { Quema de imágenes. }\end{array}$ & Desconocido & $\begin{array}{l}\text { P-S Madrid } \\
\text { L.1536 }\end{array}$ \\
\hline Rota & $17-4-36$ & $\begin{array}{l}\text { Asalto y saqueo de una iglesia. } \\
\text { Quema de imágenes y objetos de } \\
\text { culto. }\end{array}$ & Desconocido & \begin{tabular}{|l|} 
Nunz. C. 925, F. 1 \\
P-S Madrid L. \\
2376 \\
\end{tabular} \\
\hline San Fernando & $8-3-36$ & $\begin{array}{l}\text { Asalto y saqueo de una iglesia. } \\
\text { Destrozo de imágenes. }\end{array}$ & Comunistas & $\begin{array}{l}\text { Nunz. C. } 945, \text { F. } 3 \\
\text { P-S Madrid } \\
\text { L.1536 y } 152 \\
\text { DSC, } 15 \text {-IV-1936 } \\
\end{array}$ \\
\hline San Roque & $11-5-36$ & $\begin{array}{l}\text { Asalto y ocupación de una } \\
\text { iglesia. }\end{array}$ & Socialistas & $\begin{array}{l}\text { P-S Madrid L. } \\
2376\end{array}$ \\
\hline $\begin{array}{l}\text { Setenil de las } \\
\text { Bodegas }\end{array}$ & $5-36$ & $\begin{array}{l}\text { Asalto y saqueo de "todas"las } \\
\text { iglesias (al menos dos). Destrozo } \\
\text { del mobiliario. }\end{array}$ & Desconocido & $\begin{array}{l}\text { Nunz. C. } 925, \\
\text { F. } 1\end{array}$ \\
\hline
\end{tabular}




\begin{tabular}{|c|c|c|c|c|}
\hline $\begin{array}{l}\text { Provincia y } \\
\text { Localidad }\end{array}$ & Fecha & Tipo de Violencia & Autoría & Fuente \\
\hline Ubrique & $\begin{array}{c}17 \text { y } 18 \\
4-36\end{array}$ & $\begin{array}{l}\text { Conato de asalto a un convento. } \\
\text { Asalto y saqueo de una iglesia. } \\
\text { Destrozo de objetos de culto. }\end{array}$ & Desconocido & $\begin{array}{l}\text { Nunz. C. 925, F. } 1 \\
\text { P-S Madrid L. } \\
2376\end{array}$ \\
\hline $\begin{array}{l}\text { Villaluenga } \\
\text { del Rosario }\end{array}$ & $21-4-36$ & $\begin{array}{l}\text { Asalto y saqueo de una iglesia. } \\
\text { Destrozo del mobiliario. }\end{array}$ & Desconocido & $\begin{array}{l}\text { Nunz. C. } 925, \\
\text { F. } 1\end{array}$ \\
\hline \multicolumn{5}{|c|}{ CASTELLÓN } \\
\hline $\begin{array}{l}\text { Alcora (Araya } \\
\text { y La Foya) }\end{array}$ & $14-5-36$ & $\begin{array}{l}\text { Asalto y saqueo de una iglesia. } \\
\text { Robo de objetos de culto. }\end{array}$ & Desconocido & \begin{tabular}{|l|} 
Nunz. C. 925, \\
F. 1 \\
\end{tabular} \\
\hline Azuébar & $3-36$ & $\begin{array}{l}\text { Asalto y saqueo de la iglesia. } \\
\text { Destrozo de imágenes. }\end{array}$ & Desconocido & \begin{tabular}{|l|} 
Nunz. C. 945, \\
F. 3 \\
\end{tabular} \\
\hline Burriana & $26-5-36$ & $\begin{array}{l}\text { Asalto y saqueo de una iglesia. } \\
\text { Robo de objetos de culto. }\end{array}$ & Desconocido & $\begin{array}{l}\text { Nunz. C. } 925, \\
\text { F. } 1\end{array}$ \\
\hline La Llosa & $6-6-36$ & $\begin{array}{l}\text { Asalto y saqueo de la iglesia. } \\
\text { Robo de objetos de culto. }\end{array}$ & Desconocido & $A B C, 7-\mathrm{VI}-1936$ \\
\hline Navajas & $3-36$ & $\begin{array}{l}\text { Asalto y saqueo de la iglesia. } \\
\text { Destrozo de imágenes. }\end{array}$ & Desconocido & \begin{tabular}{|l} 
Nunz. C. 945, \\
F. 3
\end{tabular} \\
\hline $\begin{array}{l}\text { Oropesa del } \\
\text { Mar }\end{array}$ & $13-5-36$ & $\begin{array}{l}\text { Asalto y saqueo de una ermita. } \\
\text { Robo de objetos de culto. }\end{array}$ & Desconocido & \begin{tabular}{|l|} 
Nunz. C. 925, \\
F. 1 \\
\end{tabular} \\
\hline Sarratella & $21-2-36$ & Asalto y ocupación de la iglesia. & Desconocido & $\begin{array}{l}\text { P-S Madrid L. } 152 \\
\text { Nunz. C. } 912 \\
\text { DSC, 15-IV-1936 } \\
\end{array}$ \\
\hline $\begin{array}{l}\text { Villarreal de } \\
\text { los Infantes }\end{array}$ & $1-5-36$ & $\begin{array}{l}\text { Destrozo de cruces y estaciones } \\
\text { del Vía Crucis. }\end{array}$ & Desconocido & $\begin{array}{l}\text { Nunz. C. } 925, \\
\text { F. } 1\end{array}$ \\
\hline \multicolumn{5}{|c|}{ CIUDAD REAL } \\
\hline $\begin{array}{l}\text { Alcázar de } \\
\text { San Juan }\end{array}$ & $29-3-36$ & $\begin{array}{l}\text { Conato de incendio de una } \\
\text { iglesia. }\end{array}$ & Desconocido & \begin{tabular}{|l|} 
Nunz. C. 925, F. 1 \\
P-S Madrid L. 152 \\
\end{tabular} \\
\hline Almagro & $18-2-36$ & $\begin{array}{l}\text { Derribo de tres cruces } \\
\text { monumentales. }\end{array}$ & Desconocido & $\begin{array}{l}\text { P-S Madrid } \\
\text { L.1536 } \\
D S C, 15-I V-1936 \\
\end{array}$ \\
\hline Chillón & $21-2-36$ & Asalto de una ermita. & Desconocido & $\begin{array}{l}\text { Nunz. C. } 945, \text { F. } 3 \\
\text { P-S Madrid } \\
\text { L.1536 y } 152 \\
\text { DSC, } 15-\mathrm{IV}-1936 \\
\end{array}$ \\
\hline Los Cortijos & $4-36$ & Asalto y ocupación de la casa rectoral. & Desconocido & Nunz. C. 925 , F. 1 \\
\hline Manzanares & $22-2-36$ & $\begin{array}{l}\text { Asalto y saqueo de una ermita. } \\
\text { Destrozo de la imagen. }\end{array}$ & Desconocido & $\begin{array}{l}\text { P-S Madrid } \\
\text { L.1536 y } 152 \\
\text { Nunz. C. } 912 \\
\text { DSC, } 15-I V-1936 \\
\end{array}$ \\
\hline Peralvillo & $4-36$ & Asalto y saqueo de una ermita. & Desconocido & \begin{tabular}{|l|} 
Nunz. C. 925, F. 1 \\
\end{tabular} \\
\hline $\begin{array}{l}\text { Puebla del } \\
\text { Príncipe }\end{array}$ & $25-4-36$ & $\begin{array}{l}\text { Incendio de la iglesia con graves } \\
\text { daños. }\end{array}$ & Desconocido & \begin{tabular}{|l|} 
Nunz.C. 925, F. 1 \\
P-S Madrid L. 2377 \\
DSC, 7-V-1936
\end{tabular} \\
\hline
\end{tabular}




\begin{tabular}{|c|c|c|c|c|}
\hline $\begin{array}{l}\text { Provincia y } \\
\text { Localidad }\end{array}$ & Fecha & Tipo de Violencia & Autoría & Fuente \\
\hline Puertollano & $2-5-36$ & Voladura de una cruz monumental. & Desconocido & $D S C, 7-\mathrm{V}-1936$ \\
\hline $\begin{array}{l}\text { Santa Cruz de } \\
\text { Mudela }\end{array}$ & $16-3-36$ & $\begin{array}{l}\text { Incendio parcial de una iglesia y } \\
\text { un convento. }\end{array}$ & Desconocido & \begin{tabular}{|l|} 
Nunz. C. 945, F. 3 \\
P-S Madrid \\
L.1536 y 152 \\
DSC, $15-\mathrm{IV}-1936$ \\
\end{tabular} \\
\hline Villahermosa & $5-36$ & $\begin{array}{l}\text { Asalto y saqueo de una ermita. } \\
\text { Destrozo de imágenes. }\end{array}$ & Desconocido & $\begin{array}{l}\text { Nunz. C. } 925, \\
\text { F. } 1\end{array}$ \\
\hline \begin{tabular}{|l|}
$\begin{array}{l}\text { Villarrubia de } \\
\text { los Ojos }\end{array}$ \\
\end{tabular} & $5-36$ & Asalto de la ermita. & Desconocido & Nunz. C. 925, F. 1 \\
\hline \multicolumn{5}{|c|}{ CÓRDOBA } \\
\hline $\begin{array}{l}\text { Aguilar de la } \\
\text { Frontera }\end{array}$ & $20-2-36$ & $\begin{array}{l}\text { Asalto a un convento. Tiene lugar } \\
\text { junto al saqueo e incendio de la } \\
\text { comunidad de labradores, juzgado, } \\
\text { oficinas municipales, registro de la } \\
\text { propiedad y sede de AP. }\end{array}$ & Desconocido & $\begin{array}{l}\text { P-S Madrid } \\
\text { L.1536 } \\
\text { DSC, 15-IV-1936 }\end{array}$ \\
\hline Espejo & $5-3-36$ & $\begin{array}{l}\text { Derribo de una cruz monumental. } \\
\text { Asalto y saqueo de una ermita. }\end{array}$ & Desconocido & $A B C, 6-$ III-1936 \\
\hline \begin{tabular}{|l|} 
Fuente \\
Ovejuna \\
(La Coronada) \\
\end{tabular} & $3-36$ & $\begin{array}{l}\text { Asalto y saqueo de la iglesia. } \\
\text { Quema de imágenes y objetos de } \\
\text { culto. }\end{array}$ & Desconocido & DSC, 16-IV-1936 \\
\hline Palma del Río & $20-2-36$ & $\begin{array}{l}\text { Incendio parcial de un convento. } \\
\text { Asalto y saqueo de dos iglesias } \\
\text { y otro convento. Destrozo } \\
\text { de las imágenes. Huida del } \\
\text { personal religioso. Se hace } \\
\text { junto a las sedes de AP y del } \\
\text { Partido Radical, tres domicilios } \\
\text { particulares y dos comercios. }\end{array}$ & Desconocido & $\begin{array}{l}\text { Nunz. C. } 945, \\
\text { F. } 3 \\
\text { P-S Madrid L. } \\
152 \text { y } 1536 \\
D S C, 15-I V-1936\end{array}$ \\
\hline \multicolumn{5}{|c|}{ CUENCA } \\
\hline Cuenca & $2-5-36$ & $\begin{array}{l}\text { Apalizan y roban a dos frailes } \\
\text { cuando desalojaban su convento. } \\
\text { Conato de asalto a un convento. } \\
\text { Tiene lugar junto al asalto de } \\
\text { una sede de AP y la quema de un } \\
\text { automóvil. } \\
\end{array}$ & Desconocido & $\begin{array}{l}\text { Nunz. C. } 925, \\
\text { F. } 1 \\
\text { P-S Madrid L. } \\
2376 \\
\text { DSC, } 7-\mathrm{V}-1936\end{array}$ \\
\hline \begin{tabular}{|l|} 
Barajas de \\
Melo \\
\end{tabular} & $5-36$ & $\begin{array}{l}\text { Asalto y ocupación de la casa } \\
\text { rectoral. }\end{array}$ & $\begin{array}{l}\text { Obreros } \\
\text { Alojados }\end{array}$ & \begin{tabular}{|l|} 
Nunz. C. 925, \\
F. 1 \\
\end{tabular} \\
\hline Boniches & $5-36$ & $\begin{array}{l}\text { Asalto y saqueo de la iglesia. } \\
\text { Quema de imágenes. Asalto y } \\
\text { ocupación de una casa rectoral. }\end{array}$ & Socialistas & $\begin{array}{l}\text { Nunz. C. } 925, \\
\text { F. } 1\end{array}$ \\
\hline Cardenete & $5-36$ & $\begin{array}{l}\text { Asalto y ocupación de la casa } \\
\text { rectoral. }\end{array}$ & Desconocido & $\begin{array}{l}\text { Nunz. C. } 925, \\
\text { F. } 1\end{array}$ \\
\hline Iniesta & $5-36$ & Asalto y ocupación de una ermita. & Desconocido & Nunz. C. 925, F. 1 \\
\hline
\end{tabular}




\begin{tabular}{|c|c|c|c|c|}
\hline $\begin{array}{l}\text { Provincia y } \\
\text { Localidad }\end{array}$ & Fecha & Tipo de Violencia & Autoría & Fuente \\
\hline $\begin{array}{l}\text { Valdemoro } \\
\text { Sierra }\end{array}$ & $5-36$ & $\begin{array}{l}\text { Asalto y saqueo de la iglesia y la } \\
\text { casa rectoral. Quema de imágenes. } \\
\text { Ocupación de la casa rectoral. }\end{array}$ & Desconocido & $\begin{array}{l}\text { Nunz. C. } 925 \text {, } \\
\text { F. } 1\end{array}$ \\
\hline \multicolumn{5}{|c|}{ GERONA } \\
\hline Gerona & $23-3-36$ & $\begin{array}{l}\text { Conato de asalto a una iglesia. } \\
\text { Destrozo de una cruz monumental. }\end{array}$ & Desconocido & $\begin{array}{l}\text { P-S Madrid L. } \\
152\end{array}$ \\
\hline \multicolumn{5}{|c|}{ GRANADA } \\
\hline Granada & $23-2-36$ & $\begin{array}{l}\text { Asalto y saqueo de un convento. } \\
\text { Robo de objetos de culto. }\end{array}$ & Desconocido & \begin{tabular}{|l|} 
Nunz. C. 912 \\
$D S C, 15-I V-1936$ \\
\end{tabular} \\
\hline Granada & $\begin{array}{c}9 y \\
10-3-36\end{array}$ & $\begin{array}{l}\text { Incendio de dos iglesias y un } \\
\text { convento con graves daños. } \\
\text { Conato de incendio en tres } \\
\text { iglesias, un convento y un } \\
\text { seminario. Tiene lugar junto al } \\
\text { incendio de las sedes de FE y } \\
\text { AP, un periódico de derechas, un } \\
\text { teatro, un café, una fábrica y tres } \\
\text { domicilios. Un capellán apalizado. }\end{array}$ & Desconocido & $\begin{array}{l}\text { Nunz. C. } 945, \\
\text { F. } 3 \\
\text { P-S Madrid } \\
\text { L.1536 y } 152 \\
\text { AGA Serie } \\
008 / 44 / C .2791 \\
D S C, 15-\text {-IV-1936 }\end{array}$ \\
\hline Granada & $30-3-36$ & Derribo de una cruz monumental. & Desconocido & $\begin{array}{l}\text { La Vanguardia, } \\
\text { 31-III-1936 } \\
\text { ABC, 1-IV-1936 } \\
\end{array}$ \\
\hline Albuñol & $5-36$ & $\begin{array}{l}\text { Asalto y ocupación de la casa } \\
\text { rectoral. }\end{array}$ & Desconocido & $\begin{array}{l}\text { Nunz. C. } 925, \\
\text { F. } 1\end{array}$ \\
\hline $\begin{array}{l}\text { Albuñol } \\
\text { (La Rábita) }\end{array}$ & $18-4-36$ & $\begin{array}{l}\text { Asalto y saqueo de la iglesia. } \\
\text { Destrozo de imágenes. }\end{array}$ & Desconocido & $\begin{array}{l}\text { Nunz. C. 925, F. } 1 \\
\text { La Vanguardia, } \\
\text { 19-IV-1936 } \\
\end{array}$ \\
\hline $\begin{array}{l}\text { Alhama de } \\
\text { Granada }\end{array}$ & $3-36$ & Asalto y saqueo de la iglesia. & Desconocido & $\begin{array}{l}\text { Nunz. C. } 925, \\
\text { F. } 1\end{array}$ \\
\hline $\begin{array}{l}\text { Alhama de } \\
\text { Granada }\end{array}$ & $4-36$ & $\begin{array}{l}\text { Asalto y saqueo de un convento. } \\
\text { Destrozo y robo de objeto de } \\
\text { culto. Asalto y destrozos en un } \\
\text { cementerio. }\end{array}$ & Desconocido & $\begin{array}{l}\text { Nunz. C. } 945, \\
\text { F. } 3\end{array}$ \\
\hline Chimeneas & $5-36$ & $\begin{array}{l}\text { Asalto y ocupación de la casa } \\
\text { rectoral. }\end{array}$ & Desconocido & \begin{tabular}{|l} 
Nunz. C. 925, \\
F. 1
\end{tabular} \\
\hline Cijuela & $4-36$ & Asalto y saqueo de la iglesia. & Desconocido & Nunz. C. 925, F. 1 \\
\hline $\begin{array}{l}\text { Dehesas } \\
\text { Viejas }\end{array}$ & $3-36$ & Asalto y saqueo de la iglesia. & Desconocido & Nunz. C. 945 , F. 3 \\
\hline Dúrcal & $5-36$ & $\begin{array}{l}\text { Asalto y ocupación de la casa } \\
\text { rectoral. }\end{array}$ & Socialistas & $\begin{array}{l}\text { Nunz. C. } 925, \\
\text { F. } 1\end{array}$ \\
\hline Gobernador & $5-36$ & Asalto y ocupación de la iglesia. & Socialistas & Nunz. C. 925, F. 1 \\
\hline Guadahortuna & $4-36$ & Asalto y saqueo de la iglesia. & Desconocido & Nunz. C. 925 , F. 1 \\
\hline
\end{tabular}




\begin{tabular}{|c|c|c|c|c|}
\hline $\begin{array}{l}\text { Provincia y } \\
\text { Localidad }\end{array}$ & Fecha & Tipo de Violencia & Autoría & Fuente \\
\hline \begin{tabular}{|l} 
Guájar \\
Faragüit
\end{tabular} & $5-36$ & $\begin{array}{l}\text { Asalto y ocupación de la casa } \\
\text { rectoral. }\end{array}$ & Desconocido & $\begin{array}{l}\text { Nunz. C. } 925, \\
\text { F. } 1\end{array}$ \\
\hline $\begin{array}{l}\text { Gualchos } \\
\text { (Castell de } \\
\text { Ferro) }\end{array}$ & $4-36$ & $\begin{array}{l}\text { Asalto y saqueo de la iglesia. } \\
\text { Asalto y ocupación de la casa } \\
\text { rectoral }\end{array}$ & Desconocido & $\begin{array}{l}\text { Nunz. C. } 925, \\
\text { F. } 1\end{array}$ \\
\hline Íllora & $26-4-36$ & $\begin{array}{l}\text { Asalto y saqueo de la iglesia. } \\
\text { Quema de imágenes y objetos de } \\
\text { culto. }\end{array}$ & Desconocido & $\begin{array}{l}\text { Nunz. C. 925, F. } 1 \\
\text { P-S Madrid L. } \\
2377\end{array}$ \\
\hline $\begin{array}{l}\text { Íllora } \\
\text { (Alomartes) }\end{array}$ & $1-5-36$ & Asalto y saqueo de la iglesia. & Desconocido & $\begin{array}{l}\text { Nunz. C. } 925, \text { F. } 1 \\
D S C, 7-V-1936\end{array}$ \\
\hline Iznalloz & $21-2-36$ & $\begin{array}{l}\text { Asalto y saqueo de la iglesia. } \\
\text { Quema de imágenes y objetos } \\
\text { de culto. Junto con un intento de } \\
\text { asalto al casino. }\end{array}$ & Desconocido & $\begin{array}{l}\text { Nunz. C. } 925, \\
\text { F. } 1 \\
\text { DSC, 15-IV-1936 }\end{array}$ \\
\hline $\begin{array}{l}\text { Iznalloz } \\
\text { (Domingo } \\
\text { Pérez) } \\
\end{array}$ & $5-36$ & $\begin{array}{l}\text { Asalto y ocupación de la casa } \\
\text { rectoral. }\end{array}$ & Desconocido & $\begin{array}{l}\text { Nunz. C. } 925, \\
\text { F. } 1\end{array}$ \\
\hline \begin{tabular}{|l|} 
La Peza (Los \\
Villares) \\
\end{tabular} & $5-36$ & $\begin{array}{l}\text { Asalto y ocupación de la casa } \\
\text { rectoral. }\end{array}$ & Desconocido & $\begin{array}{l}\text { Nunz. C. } 925, \\
\text { F. } 1\end{array}$ \\
\hline La Zubia & $19-4-36$ & $\begin{array}{l}\text { Asalto y saqueo del centro de } \\
\text { Acción Católica y quema del } \\
\text { mobiliario. Tiene lugar junto al } \\
\text { asalto de un domicilio particular. }\end{array}$ & Desconocido & $\begin{array}{l}\text { P-S Madrid L. } \\
2376\end{array}$ \\
\hline Lanjarón & $20-4-36$ & $\begin{array}{l}\text { Asalto y saqueo de la iglesia. } \\
\text { Quema de imágenes y objetos de } \\
\text { culto. }\end{array}$ & Desconocido & \begin{tabular}{|l|} 
Nunz. C. 925, F. 1 \\
P-S Madrid L. \\
2376 y 2377 \\
\end{tabular} \\
\hline Lanjarón & $22-4-36$ & $\begin{array}{l}\text { Lanzamiento de una botella de } \\
\text { líquido inflamable contra la iglesia }\end{array}$ & Desconocido & $D S C, 7-\mathrm{V}-1936$ \\
\hline $\begin{array}{l}\text { Moclín } \\
\text { (Olivares) }\end{array}$ & $4-36$ & Asalto y saqueo de la iglesia. & Desconocido & $\begin{array}{l}\text { Nunz. C. } 925, \\
\text { F. } 1\end{array}$ \\
\hline $\begin{array}{l}\text { Moclín } \\
\text { (Tiena) }\end{array}$ & $4-36$ & Asalto y saqueo de la iglesia. & Desconocido & $\begin{array}{l}\text { Nunz. C. } 925, \\
\text { F. } 1\end{array}$ \\
\hline Motril & $5-36$ & $\begin{array}{l}\text { Derribo de cuatro cruces } \\
\text { monumentales. }\end{array}$ & Desconocido & $\begin{array}{l}\text { Nunz. C. } 925, \\
\text { F. } 1\end{array}$ \\
\hline $\begin{array}{l}\text { Motril (El } \\
\text { Varadero) }\end{array}$ & $6-5-36$ & Asalto y saqueo de una ermita. & Desconocido & $\begin{array}{l}\text { Nunz. C. 925, F. } 1 \\
\text { La Vanguardia, } \\
\text { 7-V-1936 } \\
\end{array}$ \\
\hline Pinos Genil & -36 & Apedreamiento del cura. & Desconocido & Nunz. C. 925, F. 1 \\
\hline $\begin{array}{l}\text { Pinos Puente } \\
\text { (Asquerosa) }\end{array}$ & $28-4-36$ & $\begin{array}{l}\text { Asalto y saqueo de la casa } \\
\text { rectoral. Incendio parcial de la } \\
\text { iglesia. Quema de imágenes y } \\
\text { objetos de culto. }\end{array}$ & Desconocido & $\begin{array}{l}\text { Nunz. C. } 925, \\
\text { F. } 1 \\
\text { P-S Madrid L. } \\
2377 \\
\end{array}$ \\
\hline
\end{tabular}




\begin{tabular}{|c|c|c|c|c|}
\hline $\begin{array}{l}\text { Provincia y } \\
\text { Localidad }\end{array}$ & Fecha & Tipo de Violencia & Autoría & Fuente \\
\hline $\begin{array}{l}\text { Pinos Puente } \\
\text { (Zujaira) }\end{array}$ & $3-36$ & $\begin{array}{l}\text { Incendio de la iglesia con graves } \\
\text { daños. }\end{array}$ & Desconocido & $\begin{array}{l}\text { Nunz. C. } 945, \\
\text { F. } 3\end{array}$ \\
\hline $\begin{array}{l}\text { Puebla de } \\
\text { Don Fadrique } \\
\text { (Bugéjar) }\end{array}$ & $5-36$ & $\begin{array}{l}\text { Incendio de una ermita con } \\
\text { graves daños. }\end{array}$ & Desconocido & $\begin{array}{l}\text { P-S Madrid L. } \\
4550\end{array}$ \\
\hline Quéntar & $5-36$ & Asalto y ocupación de la sacristía. & Socialistas & Nunz. C. 925, F. 1 \\
\hline \multicolumn{5}{|c|}{ GUADALAJARA } \\
\hline $\begin{array}{l}\text { Ciruelos del } \\
\text { Pinar }\end{array}$ & $5-36$ & $\begin{array}{l}\text { Asalto y ocupación de la casa } \\
\text { rectoral. }\end{array}$ & Desconocido & \begin{tabular}{|l} 
Nunz. C. 925, \\
F. 1
\end{tabular} \\
\hline Horche & $17-2-36$ & $\begin{array}{l}\text { Asalto y saqueo de una ermita. } \\
\text { Robo de la imagen. }\end{array}$ & Desconocido & \begin{tabular}{|l} 
P-S Madrid \\
L.1536 \\
ADT, Secretaría
\end{tabular} \\
\hline $\begin{array}{l}\text { Riba de } \\
\text { Saelices }\end{array}$ & $19-3-36$ & $\begin{array}{l}\text { Asalto y saqueo de una ermita. } \\
\text { Quema de imágenes. }\end{array}$ & Desconocido & $\begin{array}{l}\text { Nunz. C. } 945, \\
\text { F. } 3\end{array}$ \\
\hline Tordesilos & $5-36$ & $\begin{array}{l}\text { Asalto y ocupación de la casa } \\
\text { rectoral. }\end{array}$ & Desconocido & $\begin{array}{l}\text { Nunz. C. } 925, \\
\text { F. } 1\end{array}$ \\
\hline \multicolumn{5}{|c|}{ HUELVA } \\
\hline Calañas & $3-36$ & $\begin{array}{l}\text { Asalto y saqueo de la casa } \\
\text { rectoral y de una ermita. }\end{array}$ & Desconocido & \begin{tabular}{|l|} 
P-S Madrid \\
L.1536 \\
\end{tabular} \\
\hline El Almendro & $16-4-36$ & $\begin{array}{l}\text { Asalto y saqueo de la casa } \\
\text { rectoral. Incendio de una ermita } \\
\text { con daños graves. Robo de } \\
\text { objetos de culto y del cepillo. }\end{array}$ & Desconocido & \begin{tabular}{|l|} 
Nunz. C. 945, \\
F. 3 \\
P-S Madrid \\
L.1536 y 152 \\
DSC, $7-$ V-1936 \\
\end{tabular} \\
\hline Galaroza & $21-3-36$ & $\begin{array}{l}\text { Asalto y saqueo de la casa } \\
\text { rectoral. Incendio parcial de una } \\
\text { ermita. }\end{array}$ & Desconocido & \begin{tabular}{|l} 
Nunz. C. 945, F. 3 \\
P-S Madrid \\
L.1536 y 152
\end{tabular} \\
\hline $\begin{array}{l}\text { La Palma del } \\
\text { Condado }\end{array}$ & $18-3-36$ & $\begin{array}{l}\text { Derribo de un monumento al } \\
\text { Sagrado Corazón. }\end{array}$ & Desconocido & $\begin{array}{l}\text { Nunz. C. 945, F. } 3 \\
\text { La Vanguardia, } \\
\text { 18-III-1936 } \\
\end{array}$ \\
\hline Niebla & $7-3-36$ & $\begin{array}{l}\text { Incendio de una iglesia con } \\
\text { graves daños. }\end{array}$ & Desconocido & $\begin{array}{l}\text { Nunz. C. } 945, \text { F. } 3 \\
\text { P-S Madrid } \\
\text { L.1536 y } 152 \\
D S C, 15-I V-1936\end{array}$ \\
\hline $\begin{array}{l}\text { Villanueva de } \\
\text { los Castillejos }\end{array}$ & $3-36$ & $\begin{array}{l}\text { Asalto y saqueo de la casa } \\
\text { rectoral y de una ermita. }\end{array}$ & Desconocido & $\begin{array}{l}\text { P-S Madrid } \\
\text { L.1536 }\end{array}$ \\
\hline \multicolumn{5}{|c|}{ HUESCA } \\
\hline Almudévar & $16-3-36$ & $\begin{array}{l}\text { Asalto y saqueo de una iglesia. } \\
\text { Quema de imágenes y objetos de } \\
\text { culto. }\end{array}$ & Desconocido & $\begin{array}{l}\text { Nunz. C. } 945, \text { F. } 3 \\
\text { P-S Madrid } \\
\text { L.1536 y } 152 \\
\text { DSC, } 15-\text { IV-1936 }\end{array}$ \\
\hline
\end{tabular}




\begin{tabular}{|c|c|c|c|c|}
\hline $\begin{array}{l}\text { Provincia y } \\
\text { Localidad }\end{array}$ & Fecha & Tipo de Violencia & Autoría & Fuente \\
\hline Asoveral & $25-2-36$ & $\begin{array}{l}\text { Asalto de la iglesia y vandalismo } \\
\text { contra el campanario. }\end{array}$ & Desconocido & $\begin{array}{l}\text { Nunz. C. } 945, \\
\text { F. } 3\end{array}$ \\
\hline Boltaña & $29-3-36$ & $\begin{array}{l}\text { Asalto a la iglesia y robo de los } \\
\text { badajos de las campanas. }\end{array}$ & Desconocido & $\begin{array}{l}\text { Nunz. C. } 925, \\
\text { F. } 1\end{array}$ \\
\hline Burceat & $12-4-36$ & $\begin{array}{l}\text { Asalto a la iglesia y robo de los } \\
\text { badajos de las campanas. }\end{array}$ & Desconocido & \begin{tabular}{|l} 
Nunz. C. 925, \\
F. 1
\end{tabular} \\
\hline Costean & $7-3-36$ & $\begin{array}{l}\text { Asalto a la iglesia y robo de los } \\
\text { badajos de las campanas. }\end{array}$ & Desconocido & \begin{tabular}{|l|} 
Nunz. C. 925, \\
F. 1 \\
\end{tabular} \\
\hline Costean & $31-3-36$ & Asalto a la iglesia y robo del cepillo. & Desconocido & Nunz. C. 925, F. 1 \\
\hline $\begin{array}{l}\text { Hoz de } \\
\text { Barbastro }\end{array}$ & $27-3-36$ & $\begin{array}{l}\text { Asalto a la iglesia y robo de los } \\
\text { badajos de las campanas. }\end{array}$ & Desconocido & $\begin{array}{l}\text { Nunz. C. } 925, \\
\text { F. } 1\end{array}$ \\
\hline Jaca & $11-5-36$ & $\begin{array}{l}\text { Asalto y destrozo de la sede de } \\
\text { Acción Católica. Asalto de un } \\
\text { convento. }\end{array}$ & Desconocido & $\begin{array}{l}\text { Nunz. C. } 925, \\
\text { F. } 1 \\
\text { P-S Madrid L. } \\
2376 \\
\end{array}$ \\
\hline $\begin{array}{l}\text { Ligüerre de } \\
\text { Ara } \\
\end{array}$ & $3-36$ & $\begin{array}{l}\text { Asalto a una ermita y destrozo de } \\
\text { imágenes. }\end{array}$ & Desconocido & $\begin{array}{l}\text { Nunz. C. } 925, \\
\text { F. } 1\end{array}$ \\
\hline \multicolumn{5}{|c|}{ JAÉN } \\
\hline Jaén & $27-5-36$ & $\begin{array}{l}\text { Derribo y destrucción de una cruz } \\
\text { monumental. }\end{array}$ & Desconocido & $\begin{array}{l}\text { La Vanguardia, } \\
28-\mathrm{V}-1936\end{array}$ \\
\hline Baeza & $\begin{array}{c}30 y \\
31-3-36\end{array} \mid$ & $\begin{array}{l}\text { Asalto y saqueo de una ermita. } \\
\text { Robo de imágenes y objetos de } \\
\text { culto. Conato de incendio en una } \\
\text { iglesia. Después asalto y saqueo } \\
\text { de esa iglesia. Destrozo de } \\
\text { mobiliario y ocupación. } \\
\end{array}$ & Desconocido & $\begin{array}{l}\text { Nunz. C. } 925, \\
\text { F. } 1 \\
\text { P-S Madrid } \\
\text { L.1536 }\end{array}$ \\
\hline Cazorla & $5-36$ & $\begin{array}{l}\text { Asalto y saqueo de una ermita. } \\
\text { Destrozo de mobiliario. }\end{array}$ & Desconocido & $\begin{array}{l}\text { Nunz. C. } 925, \\
\text { F. } 1 \\
\text { DSC, } 8 \text {-VII-36 }\end{array}$ \\
\hline \multicolumn{5}{|c|}{ LA CORUÑ̃A } \\
\hline La Coruña & $\begin{array}{c}19 y \\
20-2-36\end{array}$ & $\begin{array}{l}\text { Incendio de una iglesia con graves } \\
\text { daños. Golpean al sacristán. Robo } \\
\text { de objetos de valor. Destrozo de } \\
\text { crucifijos e imágenes. Conato de } \\
\text { incendio en cinco iglesias. }\end{array}$ & Desconocido & $\begin{array}{l}\text { Nunz. C. } 945, \\
\text { F. } 3 \\
\text { P-S Madrid L. } \\
152 \text { y } 1536\end{array}$ \\
\hline La Coruña & $21-2-36$ & Incendio parcial en otra iglesia. & Desconocido & \begin{tabular}{|l|} 
P-S Madrid \\
L.1536 y 152 \\
\end{tabular} \\
\hline La Coruña & $23-2-36$ & Conato de incendio en una ermita. & Desconocido & Nunz. C. 912 \\
\hline La Coruña & $26-2-36$ & $\begin{array}{l}\text { Asalto y ocupación de un } \\
\text { convento. }\end{array}$ & Socialistas & $\begin{array}{l}\text { P-S Madrid } \\
\text { L.1536 }\end{array}$ \\
\hline
\end{tabular}




\begin{tabular}{|c|c|c|c|c|}
\hline $\begin{array}{l}\text { Provincia y } \\
\text { Localidad }\end{array}$ & Fecha & Tipo de Violencia & Autoría & Fuente \\
\hline La Coruña & $18-3-36$ & $\begin{array}{l}\text { Conato de incendio en un } \\
\text { convento. Tiene lugar junto al } \\
\text { asalto y saqueo del Club Náutico y } \\
\text { de las sedes de AP y RE. Conato de } \\
\text { asalto de un periódico de derecha. }\end{array}$ & Desconocido & $\begin{array}{l}\text { P-S Madrid } \\
\text { L.1536 } \\
D S C, 15-I V-1936\end{array}$ \\
\hline La Coruña & $20-3-36$ & $\begin{array}{l}\text { Asalto y saqueo de la sede de } \\
\text { Acción Católica. Junto con el de } \\
\text { la Asociación Patronal. }\end{array}$ & Desconocido & $\begin{array}{l}\text { Nunz. C. } 912 \\
\text { P-S Madrid } \\
\text { L.1536 } \\
\text { DSC, } 15-\text { IV-1936 } \\
\end{array}$ \\
\hline $\begin{array}{l}\text { Abeg } \\
\text { (Prese }\end{array}$ & $31-5-36$ & Asalto y saqueo de la iglesia. & Desconocido & \begin{tabular}{|l} 
Nunz. C. 925, \\
F. 1
\end{tabular} \\
\hline $\begin{array}{l}\text { Bergondo (El } \\
\text { Villar) }\end{array}$ & $29-2-36$ & $\begin{array}{l}\text { Conato de incendio en la iglesia. } \\
\text { Destrucción de imágenes. }\end{array}$ & Desconocido & \begin{tabular}{|l|} 
Nunz. C. 945, F. 3 \\
La Vanguardia, \\
1 -III-36 \\
DSC, $15-$ IV-1936 \\
\end{tabular} \\
\hline \begin{tabular}{|l|}
$\begin{array}{l}\text { Bergondo } \\
\text { (Vijoy) }\end{array}$ \\
\end{tabular} & $5-36$ & Asalto y saqueo de la iglesia. & Desconocido & \begin{tabular}{|l|} 
Nunz. C. 925, \\
F. 1 \\
\end{tabular} \\
\hline Betanzos & $20-2-36$ & $\begin{array}{l}\text { Asalto de dos conventos. Quema } \\
\text { de mobiliario. Tiene lugar junto } \\
\text { al asalto de una sede de AP y de } \\
\text { un centro recreativo. }\end{array}$ & Desconocido & \begin{tabular}{|l|} 
P-S Madrid L. \\
152 \\
Nunz. C. 912 \\
$D S C, 15-I V-1936$ \\
\end{tabular} \\
\hline Betanzos & $23-2-36$ & Conato de incendio en una iglesia & Desconocido & \begin{tabular}{|l|} 
P-S Madrid L. 152 \\
Nunz. C. 912 \\
\end{tabular} \\
\hline $\begin{array}{l}\text { Betanzos } \\
\text { (Requián) }\end{array}$ & $3-36$ & $\begin{array}{l}\text { Asalto y saqueo de la iglesia y la } \\
\text { casa rectoral. Robo de objetos de } \\
\text { culto. }\end{array}$ & Desconocido & $\begin{array}{l}\text { Nunz. C. } 945 \text {, } \\
\text { F. } 3\end{array}$ \\
\hline Betanzos & $26-4-36$ & $\begin{array}{l}\text { Asalto de un convento. Robo de } \\
\text { objetos de culto }\end{array}$ & Desconocido & DSC, 7-V-1936 \\
\hline Brión (Ons) & $23-5-36$ & $\begin{array}{l}\text { Asalto y saqueo de la iglesia. Robo } \\
\text { de los badajos de las campanas. }\end{array}$ & Desconocido & \begin{tabular}{|l} 
Nunz. C. 925, \\
F. 1
\end{tabular} \\
\hline \begin{tabular}{|l|}
$\begin{array}{l}\text { Brión } \\
\text { (Viceso) }\end{array}$ \\
\end{tabular} & $23-5-36$ & $\begin{array}{l}\text { Asalto y saqueo de la iglesia. Robo } \\
\text { de los badajos de las campanas. }\end{array}$ & Desconocido & \begin{tabular}{|l} 
Nunz. C. 925, \\
F. 1
\end{tabular} \\
\hline \begin{tabular}{|l|} 
Cesuras \\
(Dordaño)
\end{tabular} & $9-4-36$ & $\begin{array}{l}\text { Asalto y saqueo de la iglesia. } \\
\text { Robo de la campana. }\end{array}$ & Desconocido & $\begin{array}{l}\text { Nunz. C. } 925, \\
\text { F. } 1\end{array}$ \\
\hline $\begin{array}{l}\text { Culleredo } \\
\text { (Almeiras) }\end{array}$ & $26-4-36$ & $\begin{array}{l}\text { Incendio de la iglesia con graves } \\
\text { daños. }\end{array}$ & Desconocido & $\begin{array}{l}\text { Nunz. C. 925, F. } 1 \\
\text { P-S Madrid L. } \\
2377 \\
D S C, 7-V-1936\end{array}$ \\
\hline El Eijo & $25-5-36$ & $\begin{array}{l}\text { Asalto y saqueo de una ermita. } \\
\text { Robo de objetos de culto. }\end{array}$ & Desconocido & \begin{tabular}{|l} 
Nunz. C. 925, \\
F. 1
\end{tabular} \\
\hline
\end{tabular}




\begin{tabular}{|c|c|c|c|c|}
\hline $\begin{array}{l}\text { Provincia y } \\
\text { Localidad }\end{array}$ & Fecha & Tipo de Violencia & Autoría & Fuente \\
\hline El Ferrol & $20-2-36$ & $\begin{array}{l}\text { Asalto y saqueo de una residencia } \\
\text { religiosa. Incendio del mobiliario } \\
\text { y objetos de culto. Al tiempo que } \\
\text { las sedes de AP y FE, y el casino } \\
\text { ferrolano. }\end{array}$ & Desc & $\begin{array}{l}\text { Nunz. C. } 945, \\
\text { F. } 3 \\
\text { P-S Madrid } \\
\text { L.1536 y } 152 \\
\text { DSC }, 15-\text { IV-1936 }\end{array}$ \\
\hline El Ferrol & $28-2-36$ & $\begin{array}{l}\text { Incendio parcial de una iglesia. } \\
\text { Quema de imágenes }\end{array}$ & Desconocido & $\begin{array}{l}\text { P-S Madrid L. } 152 \\
\text { Nunz. C. } 912 \\
\end{array}$ \\
\hline $\begin{array}{l}\text { El Ferrol } \\
\text { (Serantes) }\end{array}$ & $20-2-36$ & $\begin{array}{l}\text { Asalto y saqueo de la vivienda del } \\
\text { párroco. Quema del mobiliario y } \\
\text { objetos en la calle. Robo de dinero. } \\
\text { El párroco huyó y pudo salvarse. }\end{array}$ & Desconocido & $\begin{array}{l}\text { Nunz. C. } 945, \\
\text { F. } 3 \\
\text { P-S Madrid } \\
\text { L.1536 }\end{array}$ \\
\hline El Ferrol & $30-4-36$ & $\begin{array}{l}\text { Asalto y ocupación de un } \\
\text { convento. }\end{array}$ & Comunistas & $D S C, 7-\mathrm{V}-1936$ \\
\hline $\begin{array}{l}\text { El Ferrol } \\
\text { (Serantes) }\end{array}$ & $26-2-36$ & $\begin{array}{l}\text { Incendio parcial de la iglesia. } \\
\text { Quema de imágenes y mobiliario. }\end{array}$ & nocido & $\begin{array}{l}\text { Nunz. C. } 945 \text {, F. } 3 \\
\text { P-S Madrid } \\
\text { L.1536 } \\
\end{array}$ \\
\hline $\begin{array}{l}\text { El Ferrol } \\
\text { (Serantes) }\end{array}$ & $27-2-36$ & $\begin{array}{l}\text { Incendio de la iglesia con graves } \\
\text { daños. }\end{array}$ & Desconocido & $\begin{array}{l}\text { Nunz. C. } 945 \text {, F. } 3 \\
\text { P-S Madrid } \\
\text { L.1536 } \\
\end{array}$ \\
\hline $\begin{array}{l}\text { El Ferrol } \\
\text { (Serantes) }\end{array}$ & $3-36$ & $\begin{array}{l}\text { Cona } \\
\text { la pa }\end{array}$ & Desconocido & $\begin{array}{l}\text { Nunz. C. } 945, \\
\text { F. } 3\end{array}$ \\
\hline $\begin{array}{l}\text { El Ferrol } \\
\text { (Caranza) }\end{array}$ & $20-2-36$ & $\begin{array}{l}\text { Incendio de la iglesia con graves } \\
\text { daños. }\end{array}$ & Desconocido & $\begin{array}{l}\text { Nunz. C. } 945 \text {, F. } 3 \\
\text { P-S Madrid } \\
\text { L.1536 } \\
\end{array}$ \\
\hline Fene & $29-3-36$ & $\begin{array}{l}\text { Incendio } \\
\text { daños. }\end{array}$ & Desconocido & \begin{tabular}{|l|} 
P-S Madrid L. \\
152
\end{tabular} \\
\hline \begin{tabular}{|l|}
$\begin{array}{l}\text { Fene } \\
\text { (Filgueira) }\end{array}$ \\
\end{tabular} & $3-36$ & Conato de incendio en iglesia. & Desconocido & \begin{tabular}{|l|} 
Nunz. C. 945, \\
F. 3 \\
\end{tabular} \\
\hline $\begin{array}{l}\text { Fene } \\
\text { (Limodre) }\end{array}$ & $29-2-36$ & $\begin{array}{l}\text { Incendio de la iglesia con graves } \\
\text { daños. }\end{array}$ & Desconocido & $\begin{array}{l}\text { Nunz. C. } 945, \text { F. } 3 \\
\text { y } 912 \\
\text { P-S Madrid L. } 152 \\
D S C, 15-I V-1936\end{array}$ \\
\hline $\begin{array}{l}\text { Fene } \\
\text { (Maniños) }\end{array}$ & $3-36$ & $\begin{array}{l}\text { Asalto y saqueo de una iglesia. } \\
\text { Quema de imágenes. }\end{array}$ & Desconocido & \begin{tabular}{|l} 
Nunz. C. 945, \\
F. 3
\end{tabular} \\
\hline Fene (Perlio) & $20-2-36$ & $\begin{array}{l}\text { Incendio parcial de la iglesia. } \\
\text { Quema de imágenes. }\end{array}$ & Desconocido & \begin{tabular}{|l|} 
P-S Madrid \\
L.1536 \\
\end{tabular} \\
\hline \begin{tabular}{|l|}
$\begin{array}{l}\text { Irijoa } \\
\text { (Mantaras) }\end{array}$ \\
\end{tabular} & 9-4-36 & Asalto y saqueo de la iglesia. & Desconocido & $\begin{array}{l}\text { Nunz. C. } 925, \\
\text { F. } 1\end{array}$ \\
\hline \begin{tabular}{|l|} 
Moeche \\
(Labacencos)
\end{tabular} & $23-3-36$ & $\begin{array}{l}\text { Asalto y saqueo de la iglesia. } \\
\text { Destrozo del mobiliario. }\end{array}$ & Desconocido & \begin{tabular}{|l|} 
Nunz. C. 945, \\
F. 3
\end{tabular} \\
\hline Noya & $5-5-36$ & $\begin{array}{l}\text { Asalto al centro de la Acción } \\
\text { Católica. }\end{array}$ & Desconocido & \begin{tabular}{|l|} 
Nunz. C. $925, \mathrm{~F}$. \\
1 DSC, 7-V-1936 \\
\end{tabular} \\
\hline
\end{tabular}




\begin{tabular}{|c|c|c|c|c|}
\hline $\begin{array}{c}\text { Provincia y } \\
\text { Localidad }\end{array}$ & Fecha & Tipo de Violencia & Autoría & Fuente \\
\hline Oleiros (Iñás) & $30-4-36$ & Incendio parcial de la iglesia. & Desconocido & \begin{tabular}{|l} 
Nunz. C. 925, F. 1 \\
$D S C, 7-\mathrm{V}-1936$
\end{tabular} \\
\hline $\begin{array}{l}\text { Oleiros } \\
\text { (Meirás) }\end{array}$ & $17-5-36$ & $\begin{array}{l}\text { Asalto y saqueo de la casa } \\
\text { rectoral. }\end{array}$ & Desconocido & Nunz. C. 925 , F. 1 \\
\hline Oleiros (Nos) & $30-4-36$ & Incendio parcial de la iglesia. & Desconocido & Nunz. C. 925 , F. 1 \\
\hline $\begin{array}{l}\text { Órdenes } \\
\text { (Leira) }\end{array}$ & $2-5-36$ & Conato de incendio de una iglesia. & Desconocido & Nunz. C. 925 , F. 1 \\
\hline $\begin{array}{l}\text { Órdenes } \\
\text { (Montaos) }\end{array}$ & $17-5-36$ & $\begin{array}{l}\text { Arrojan una bomba en la casa } \\
\text { rectoral. }\end{array}$ & Desconocido & Nunz. C. 925 , F. 1 \\
\hline $\begin{array}{l}\text { Santa Comba } \\
\text { (Vilaboa) }\end{array}$ & $6-5-36$ & $\begin{array}{l}\text { Asalto y ocupación de la casa } \\
\text { rectoral. }\end{array}$ & Socialistas & Nunz. C. 925, F. 1 \\
\hline $\begin{array}{l}\text { Santiago de } \\
\text { Compostela }\end{array}$ & $\begin{array}{c}19 y \\
20-2-36\end{array} \mid$ & $\begin{array}{l}\text { Asalto de dos iglesias y de tres } \\
\text { centros de Acción Católica. Tiene } \\
\text { lugar junto con el asalto de las } \\
\text { sedes de AP, tradicionalista y } \\
\text { Bloque Nacional. Robo de dinero. }\end{array}$ & Desconocido & $\begin{array}{l}\text { Nunz. C. } 945, \text { F. } 3 \\
\text { y } 912 \\
D S C, 15-I V-1936\end{array}$ \\
\hline $\begin{array}{l}\text { Santiago de } \\
\text { Compostela }\end{array}$ & $26-2-36$ & $\begin{array}{l}\text { Asalto y ocupación de un } \\
\text { convento. }\end{array}$ & Socialistas & \begin{tabular}{|l|} 
P-S Madrid \\
L.1536 \\
\end{tabular} \\
\hline Somozas & $29-3-36$ & $\begin{array}{l}\text { Asalto y saqueo de la iglesia. } \\
\text { Destrucción de imágenes. }\end{array}$ & Desconocido & $\begin{array}{l}\text { P-S Madrid L. } \\
152\end{array}$ \\
\hline $\begin{array}{l}\text { Toques } \\
\text { (Verde) }\end{array}$ & $3-36$ & Asalto de la iglesia. & Desconocido & Nunz. C. 945 , F. 3 \\
\hline \multicolumn{5}{|c|}{ LAS PALMAS } \\
\hline Las Palmas & $25-2-36$ & Conato de incendio en un convento. & Desconocido & $\begin{array}{l}\text { Nunz. C. } 945, \text { F. } 3 \\
\text { P-S Madrid } \\
\text { L.1536 } \\
\end{array}$ \\
\hline Las Palmas & $28-2-36$ & Conato de asalto de una iglesia. & Desconocido & $\begin{array}{l}\text { P-S Madrid L. } \\
152 \\
D S C, 15-\mathrm{IV}-1936 \\
\end{array}$ \\
\hline Las Palmas & $8-3-36$ & Conato de incendio en una iglesia. & Desconocido & $\begin{array}{l}\text { Nunz. C. } 945 \text {, F. } 3 \\
\text { P-S Madrid } \\
\text { L.1536 } \\
\end{array}$ \\
\hline LEÓN & & $\begin{array}{l}\text { El obispo de Astorga adujo } \\
\text { que habían sido asaltadas } \\
\text { y saqueadas, aparte de las } \\
\text { reseñadas, veintiséis iglesias - } \\
\text { con destrucción de imágenes y } \\
\text { objetos de culto- y dieciocho } \\
\text { casas rectorales. Se apedrearon } \\
\text { y tirotearon dos iglesias. }\end{array}$ & Desconocido & $\begin{array}{l}\text { Nunz. C. 945, } \\
\text { F. } 3 \\
\text { Nunz. C. 925, } \\
\text { F. } 1\end{array}$ \\
\hline León & $25-3-36$ & $\begin{array}{l}\text { Estalla una bomba en el centro de } \\
\text { Acción Católica. }\end{array}$ & Desconocido & $\begin{array}{l}\text { La Vanguardia, } \\
27-\text { III-1936 } \\
\end{array}$ \\
\hline
\end{tabular}




\begin{tabular}{|c|c|c|c|c|}
\hline $\begin{array}{l}\text { Provincia y } \\
\text { Localidad }\end{array}$ & Fecha & Tipo de Violencia & Autoría & Fuente \\
\hline Astorga & $20-5-36$ & $\begin{array}{l}\text { Estalla una bomba en la tapia de } \\
\text { un seminario. Se encuentran dos } \\
\text { explosivos con dinamita más en el } \\
\text { mismo lugar y en una iglesia. }\end{array}$ & Desconocido & $\begin{array}{l}\text { La Vanguardia, } \\
21-\mathrm{V}-1936\end{array}$ \\
\hline Bembibre & $2-6-36$ & $\begin{array}{l}\text { Asalto y saqueo de una iglesia. } \\
\text { Robo del cepillo. }\end{array}$ & Desconocido & $A B C, 3-\mathrm{VI}-1936$ \\
\hline \begin{tabular}{|l} 
Berlanga \\
del Bierzo \\
(Langre)
\end{tabular} & $3-5-36$ & $\begin{array}{l}\text { Asalto y saqueo de la iglesia. } \\
\text { Quema de imágenes. }\end{array}$ & Desconocido & DSC, 7-V-1936 \\
\hline $\begin{array}{l}\text { Corullón } \\
\text { (Paradela del } \\
\text { Río) } \\
\end{array}$ & $22-4-36$ & $\begin{array}{l}\text { Incendio de la iglesia con graves } \\
\text { daños. }\end{array}$ & Desconocido & $\begin{array}{l}\text { P-S Madrid L. } \\
2377\end{array}$ \\
\hline \begin{tabular}{|l|}
$\begin{array}{l}\text { Corullón } \\
\text { (Dragonte) }\end{array}$ \\
\end{tabular} & $1-6-36$ & $\begin{array}{l}\text { Incendio de la iglesia con graves } \\
\text { daños. }\end{array}$ & Desconocido & $\begin{array}{l}\text { La Vanguardia, } \\
2-\mathrm{VI}-1936 \\
\end{array}$ \\
\hline $\begin{array}{l}\text { Crémenes } \\
\text { (Valbuena) }\end{array}$ & $8-3-36$ & $\begin{array}{l}\text { Asalto de una iglesia. Un grupo } \\
\text { golpea fuertemente al sacerdote } \\
\text { hiriéndole de gravedad. }\end{array}$ & Desconocido & $\begin{array}{l}\text { Nunz. C. } 945 \\
\text { DSC, 15-IV-1936 }\end{array}$ \\
\hline $\begin{array}{l}\text { Vega de } \\
\text { Valcarce } \\
\text { (Ruitelán) }\end{array}$ & $20-2-36$ & Conato de incendio en la iglesia. & Desconocido & $\begin{array}{l}\text { P-S Madrid L. } \\
152 \\
\text { Nunz. C. } 912 \\
\text { DSC, } 15-\mathrm{IV}-1936 \\
\end{array}$ \\
\hline \begin{tabular}{|l} 
Vega de \\
Valcarce \\
(Ruitelán) \\
\end{tabular} & $3-36$ & $\begin{array}{l}\text { Incendio y destrucción de la } \\
\text { iglesia }\end{array}$ & Desconocido & Nunz. C. 945 , F. 3 \\
\hline \begin{tabular}{|l} 
Villafranca \\
del Bierzo \\
(Valtuille de \\
Abajo) \\
\end{tabular} & $3-5-36$ & $\begin{array}{l}\text { Incendio de la iglesia con graves } \\
\text { daños. }\end{array}$ & Desconocido & $D S C, 7-\mathrm{V}-1936$ \\
\hline \multicolumn{5}{|c|}{ LÉRIDA } \\
\hline Lérida & $23-2-36$ & $\begin{array}{l}\text { Estalla un cartucho de dinamita en } \\
\text { una casa rectoral. }\end{array}$ & Desconocido & \begin{tabular}{|l|} 
Nunz. C. 912 \\
DSC, 15-IV-1936 \\
\end{tabular} \\
\hline Lérida & $5-36$ & $\begin{array}{l}\text { Asalto y expulsión de religiosos } \\
\text { de un convento. }\end{array}$ & $\begin{array}{l}\text { Socialistas y } \\
\text { comunistas }\end{array}$ & Nunz. C. 925 , F. 1 \\
\hline \multicolumn{5}{|c|}{ LOGROÑO } \\
\hline Logroño & $14-3-36$ & $\begin{array}{l}\text { Incendio de cuatro conventos, } \\
\text { tres iglesias, un colegio y la casa } \\
\text { de un capellán, con graves daños. } \\
\text { Incendio parcial de otro colegio } \\
\text { y de dos iglesias. Se hace de } \\
\text { forma conjunta con cinco sedes } \\
\text { de derecha, un automóvil, una } \\
\text { farmacia y un periódico. }\end{array}$ & Desconocido & $\begin{array}{l}\text { Nunz. C. } 945 \text {, F. } 3 \\
\text { P-S Madrid } \\
\text { L.1536 y } 152 \\
\text { DSC, } 15-\text { IV-1936 }\end{array}$ \\
\hline
\end{tabular}




\begin{tabular}{|c|c|c|c|c|}
\hline $\begin{array}{l}\text { Provincia y } \\
\text { Localidad }\end{array}$ & Fecha & Tipo de Violencia & Autoría & Fuente \\
\hline $\begin{array}{l}\text { Logroño (El } \\
\text { Cortijo) }\end{array}$ & $16-3-36$ & Conato de incendio en una iglesia. & Desconocido & $\begin{array}{l}\text { Nunz. C. } 945 \text {, F. } 3 \\
\text { P-S Madrid } \\
\text { L.1536 }\end{array}$ \\
\hline Agoncillo & $16-3-36$ & Incendio parcial de una iglesia. & Desconocido & $\begin{array}{l}\text { Nunz. C. 945, F. } 3 \\
\text { P-S Madrid } \\
\text { L.1536 }\end{array}$ \\
\hline $\begin{array}{l}\text { Albelda de } \\
\text { Iregua }\end{array}$ & $15-5-36$ & $\begin{array}{l}\text { Incendio de la iglesia con graves } \\
\text { daños. }\end{array}$ & Desconocido & Nunz. C. 925, F. 1 \\
\hline Alcanadre & $\begin{array}{c}18 y \\
19-3-36\end{array}$ & $\begin{array}{l}\text { Asalto y saqueo de la iglesia. } \\
\text { Robo de las imágenes. Conato de } \\
\text { incendio en una ermita. }\end{array}$ & Desconocido & $\begin{array}{l}\text { P-S Madrid } \\
\text { L.1536 } \\
\text { Nunz. C. } 912 \\
\text { DSC, } 15-I V-1936\end{array}$ \\
\hline Ausejo & 21-3-36 & Asalto y saqueo de una ermita & Desconocido & $\begin{array}{l}\text { AHP Gobierno } \\
\text { Civil } \\
\text { Gil Andrés } \\
\text { (2000): } 393\end{array}$ \\
\hline Ausejo & $7-4-36$ & $\begin{array}{l}\text { Incendio parcial de la ermita } \\
\text { anterior }\end{array}$ & Desconocido & $\begin{array}{l}\text { AHP Gobierno } \\
\text { Civil } \\
\text { Gil Andrés } \\
\text { (2000): } 393 \\
\end{array}$ \\
\hline Briones & $11-4-36$ & $\begin{array}{l}\text { Destrozo de las cruces de un Vía } \\
\text { Crucis }\end{array}$ & Desconocido & $\begin{array}{l}\text { AHP Gobierno } \\
\text { Civil } \\
\text { Gil Andrés } \\
(2000): 393\end{array}$ \\
\hline Camprovín & $27-5-36$ & Conato de incendio en una iglesia. & Desconocido & Nunz. C. 925, F. 1 \\
\hline Ezcaray & $16-3-36$ & $\begin{array}{l}\text { Conato de incendio en un } \\
\text { convento. }\end{array}$ & Desconocido & $\begin{array}{l}\text { P-S Madrid } \\
\text { L.1536 }\end{array}$ \\
\hline Lardero & $14-3-36$ & $\begin{array}{l}\text { Incendio de la iglesia y la casa } \\
\text { rectoral con graves daños. }\end{array}$ & Desconocido & $\begin{array}{l}\text { Nunz. C. } 945 \text {, F. } 3 \\
\text { P-S Madrid L. } 152 \\
\end{array}$ \\
\hline Nájera & $14-3-36$ & Incendio parcial de una iglesia. & Desconocido & $\begin{array}{l}\text { Nunz. C. } 945, \text { F. } 3 \\
\text { P-S Madrid } \\
\text { L.1536 y } 152 \\
\end{array}$ \\
\hline Nájera & $1-5-36$ & Tiroteo a un convento. & Desconocido & DSC, $7-\mathrm{V}-1936$ \\
\hline Nalda & $10-5-36$ & $\begin{array}{l}\text { Incendio de la iglesia con graves } \\
\text { daños. Quema del mobiliario y } \\
\text { objetos de culto. }\end{array}$ & Desconocido & Nunz. C. 925 , F. 1 \\
\hline Navarrete & $14-3-36$ & $\begin{array}{l}\text { Incendio de la iglesia con graves } \\
\text { daños. }\end{array}$ & Desconocido & \begin{tabular}{|l|} 
Nunz. C. 925 \\
P-S Madrid L. 152
\end{tabular} \\
\hline $\begin{array}{l}\text { Torrecilla en } \\
\text { Cameros }\end{array}$ & $18-5-36$ & Incendio parcial de dos iglesias. & Desconocido & Nunz. C. 925 , F. 1 \\
\hline Treviana & $10-3-36$ & $\begin{array}{l}\text { Incendio de una ermita con graves } \\
\text { daños. Quema de imágenes }\end{array}$ & Desconocido & $\begin{array}{l}\text { P-S Madrid } \\
\text { L.1536 }\end{array}$ \\
\hline
\end{tabular}




\begin{tabular}{|c|c|c|c|c|}
\hline $\begin{array}{l}\text { Provincia y } \\
\text { Localidad }\end{array}$ & Fecha & Tipo de Violencia & Autoría & Fuente \\
\hline Tudelilla & 7-3-36 & Incendio parcial de una ermita. & Desconocido & $\begin{array}{l}\text { P-S Madrid L. } 152 \\
\text { Nunz. C. } 945 \\
\text { DSC, 15-IV-1936 }\end{array}$ \\
\hline Tudelilla & $16-3-36$ & $\begin{array}{l}\text { Incendio de una ermita con graves } \\
\text { daños. }\end{array}$ & Desconocido & $\begin{array}{l}\text { Nunz. C. } 945 \text {, F. } 3 \\
\text { P-S Madrid } \\
\text { L.1536 }\end{array}$ \\
\hline \begin{tabular}{l|} 
Viguera \\
(Castañares \\
de las Cuevas) \\
\end{tabular} & $16-3-36$ & Incendio parcial de la iglesia. & Desconocido & $\begin{array}{l}\text { Nunz. C. } 945 \text {, F. } 3 \\
\text { P-S Madrid } \\
\text { L.1536 } \\
\end{array}$ \\
\hline \begin{tabular}{|l|} 
Villamediana \\
de Iregua \\
\end{tabular} & 6-3-36 & Incendio parcial de la iglesia. & Desconocido & Nunz. C. 945 , F. 3 \\
\hline $\begin{array}{l}\text { Villamediana } \\
\text { de Iregua }\end{array}$ & $8-3-36$ & $\begin{array}{l}\text { Incendio de la iglesia anterior con } \\
\text { graves daños. }\end{array}$ & Desconocido & $\begin{array}{l}\text { Nunz. C. } 945, \text { F. } 3 \\
\text { P-S Madrid L. } 152 \\
\text { DSC, 15-IV-1936 }\end{array}$ \\
\hline \multicolumn{5}{|c|}{ LUGO } \\
\hline $\begin{array}{l}\text { Becerreá } \\
\text { (Cruzul) }\end{array}$ & $9-5-36$ & $\begin{array}{l}\text { Incendio de una iglesia con graves } \\
\text { daños. }\end{array}$ & Desconocido & $\begin{array}{l}\text { Nunz. C. 925, F. } 1 \\
\text { P-S Madrid L. } \\
2376 \\
\text { AGA Serie } \\
\text { 008/44/C. } 2791\end{array}$ \\
\hline $\begin{array}{l}\text { Becerreá } \\
\text { (Liber) }\end{array}$ & $5-36$ & $\begin{array}{l}\text { Incendio de una iglesia con graves } \\
\text { daños. }\end{array}$ & Desconocido & $\begin{array}{l}\text { Nunz. C. } 925, \text { F. } 1 \\
\text { AGA Serie } \\
\text { 008/44/C. } 2791 \\
\end{array}$ \\
\hline $\begin{array}{l}\text { Becerreá } \\
\text { (Vilachá) }\end{array}$ & $5-36$ & $\begin{array}{l}\text { Incendio de una iglesia con graves } \\
\text { daños. }\end{array}$ & Desconocido & $\begin{array}{l}\text { Nunz. C. } 925, \text { F. } 1 \\
\text { AGA Serie } \\
\text { 008/44/C. } 2791\end{array}$ \\
\hline $\begin{array}{l}\text { Begonte } \\
\text { (Carballido) }\end{array}$ & $23-3-36$ & $\begin{array}{l}\text { Asalto y saqueo de la iglesia. } \\
\text { Destrozo del mobiliario. }\end{array}$ & Desconocido & Nunz. C. 945 , F. 3 \\
\hline $\begin{array}{l}\text { Cervantes } \\
\text { (Castro) }\end{array}$ & $12-5-36$ & $\begin{array}{l}\text { Incendio de una iglesia con graves } \\
\text { daños. }\end{array}$ & Desconocido & $\begin{array}{l}\text { Nunz. C. 925, F. } 1 \\
\text { P-S Madrid L. } \\
\text { 2376 } \\
\text { AGA Serie } \\
\text { 008/44/C. } 2791\end{array}$ \\
\hline $\begin{array}{l}\text { Fonsagrada } \\
\text { (Vieiro) }\end{array}$ & $12-6-36$ & $\begin{array}{l}\text { Estallan varios cartuchos de } \\
\text { dinamita en una iglesia que sufre } \\
\text { graves daños. }\end{array}$ & Desconocido & Nunz. C. 925, F. 1 \\
\hline $\begin{array}{l}\text { Germade } \\
\text { (Cazas) }\end{array}$ & $19-5-36$ & $\begin{array}{l}\text { Asalto y saqueo de la iglesia con } \\
\text { graves daños. }\end{array}$ & Desconocido & Nunz. C. 925, F. 1 \\
\hline Los Nogales & $5-36$ & $\begin{array}{l}\text { Incendio parcial de una iglesia. } \\
\text { Quema de imágenes. }\end{array}$ & Desconocido & $\begin{array}{l}\text { Nunz. C. } 925, \text { F. } 1 \\
\text { AGA Serie } \\
\text { 008/44/C. } 2791 \\
\end{array}$ \\
\hline
\end{tabular}




\begin{tabular}{|c|c|c|c|c|}
\hline $\begin{array}{l}\text { Provincia y } \\
\text { Localidad }\end{array}$ & Fecha & Tipo de Violencia & Autoría & Fuente \\
\hline $\begin{array}{l}\text { Monforte } \\
\text { de Lemos } \\
\text { (Rivasaltas) } \\
\end{array}$ & $23-3-36$ & $\begin{array}{l}\text { Incendio parcial de una iglesia. } \\
\text { Robo de objetos de culto. }\end{array}$ & Desconocido & $\begin{array}{l}\text { Nunz. C. } 945 \text {, F. } 3 \\
\text { P-S Madrid } \\
\text { L.1536 } \\
\end{array}$ \\
\hline Quiroga & $5-3-36$ & Asalto de la iglesia. & Desconocido & $A B C, 6$-III-1936 \\
\hline $\begin{array}{l}\text { Quiroga } \\
\text { (Sequeiros) }\end{array}$ & 24-3-36 & $\begin{array}{l}\text { Incendio de la iglesia con graves } \\
\text { daños. }\end{array}$ & Desconocido & $\begin{array}{l}\text { P-S Madrid } \\
\text { L.1536 } \\
\text { AGA Serie } \\
\text { 008/44/C. } 2791 \\
\end{array}$ \\
\hline $\begin{array}{l}\text { Rivas del Sil } \\
\text { (Torbeo) }\end{array}$ & $2-36$ & $\begin{array}{l}\text { Asalto de la casa rectoral. La } \\
\text { iglesia fue incendiada en octubre } \\
\text { de } 1934 .\end{array}$ & Comunistas & $\begin{array}{l}\text { Nunz. C. } 945 \text {, F. } 3 \\
\text { AGA Serie } \\
008 / 44 / \text { C. } 2791 \\
\end{array}$ \\
\hline Vivero (Faro) & $25-5-36$ & $\begin{array}{l}\text { Asalto y saqueo de la iglesia. } \\
\text { Destrozo del mobiliario. }\end{array}$ & Desconocido & Nunz. C. 925, F. 1 \\
\hline \multicolumn{5}{|c|}{ MADRID } \\
\hline $\begin{array}{l}\text { Madrid } \\
\text { (Puente de } \\
\text { Vallecas y } \\
\text { Sureste) }\end{array}$ & $\begin{array}{c}10 y \\
11-3- \\
36\end{array}$ & $\begin{array}{l}\text { Incendio de dos iglesias con graves } \\
\text { daños. Incendio parcial de dos } \\
\text { conventos y un colegio. Conatos } \\
\text { de incendio en una iglesia y una } \\
\text { casa cuna. Apedreamiento, asalto } \\
\text { y saqueo de otro convento. Tiene } \\
\text { lugar junto al asalto de la sede de } \\
\text { AP y de los sindicatos católicos, } \\
\text { además de cinco comercios y un } \\
\text { domicilio particular. }\end{array}$ & Desconocido & $\begin{array}{l}\text { Nunz. C. } 945, \text { F. } 3 \\
\text { P-S Madrid } \\
\text { L.1536 y } 152 \\
\text { DSC, } 15-\text { IV-1936 }\end{array}$ \\
\hline Madrid & $\begin{array}{c}12 y \\
13-3-36\end{array}$ & $\begin{array}{l}\text { Incendio de dos iglesias con graves } \\
\text { daños. Conato de incendio de otra. } \\
\text { Tiene lugar junto al asalto de un } \\
\text { café, el saqueo de una armería y la } \\
\text { quema de un periódico de derecha. }\end{array}$ & Desconocido & $\begin{array}{l}\text { P-S Madrid L. } \\
152 \\
\text { Nunz. C. } 945 \\
\text { DSC, } 15-I V-1936\end{array}$ \\
\hline Madrid & $2-5-36$ & Incendio parcial de un convento. & Desconocido & Nunz. C. 925 \\
\hline Madrid & $\begin{array}{c}3 y \\
4-5-36\end{array}$ & $\begin{array}{l}\text { Incendio parcial o total de cuatro } \\
\text { colegios, tres iglesias y dos casas } \\
\text { rectorales. Conatos de incendio } \\
\text { en tres iglesias. Maltratos a seis } \\
\text { religiosas y a dos familiares de } \\
\text { religiosas. Una de ellas herida } \\
\text { grave. Tres sacerdotes heridos en } \\
\text { una parroquia de Cuatro Caminos. } \\
\text { Tiene lugar junto al incendio de la } \\
\text { sede de los sindicatos católicos y } \\
\text { un domicilio. } \\
\end{array}$ & Desconocido & $\begin{array}{l}\text { Nunz. C. } 925, \text { F. } 1 \\
D S C, 6 \text { y } 7-\mathrm{V}- \\
1936\end{array}$ \\
\hline $\begin{array}{l}\text { Madrid } \\
\text { (Tetuán de las } \\
\text { Victorias) }\end{array}$ & $10-5-36$ & $\begin{array}{l}\text { Asalto y saqueo de un colegio de } \\
\text { religiosas. }\end{array}$ & Desconocido & $\begin{array}{l}\text { Nunz. C. } 925, \text { F. } 1 \\
\text { DSC, } 4 \text {-VI-36 }\end{array}$ \\
\hline
\end{tabular}




\begin{tabular}{|c|c|c|c|c|}
\hline $\begin{array}{l}\text { Provincia y } \\
\text { Localidad }\end{array}$ & Fecha & Tipo de Violencia & Autoría & Fuente \\
\hline $\begin{array}{l}\text { Madrid } \\
\text { (Tetuán de las } \\
\text { Victorias) }\end{array}$ & $5-36$ & $\begin{array}{l}\text { Asalto y clausura de cinco } \\
\text { colegios religiosos. Incendio } \\
\text { parcial de "algunos de ellos" (al } \\
\text { menos dos). }\end{array}$ & $\begin{array}{l}\text { "Guardia } \\
\text { Roja" }\end{array}$ & $\begin{array}{l}\text { Nunz. C. } 925, \text { F. } 1 \\
D S C, 4-\text { II-36 }\end{array}$ \\
\hline Madrid & $5-36$ & $\begin{array}{l}\text { Asalto y clausura de ocho colegios } \\
\text { religiosos. De ellos, incendio } \\
\text { parcial o total de siete. }\end{array}$ & $\begin{array}{l}\text { "Guardia } \\
\text { Roja" }\end{array}$ & $\begin{array}{l}\text { Nunz. C. } 925, \text { F. } 1 \\
D S C, 4-V I-36\end{array}$ \\
\hline \begin{tabular}{|l} 
Madrid \\
(Puente de \\
Vallecas) \\
\end{tabular} & $23-3-36$ & $\begin{array}{l}\text { Apedreamiento de un colegio } \\
\text { religioso. }\end{array}$ & Desconocido & DSC, 15-IV-1936 \\
\hline $\begin{array}{l}\text { Madrid } \\
\text { (Puente de } \\
\text { Vallecas) } \\
\end{array}$ & $5-36$ & $\begin{array}{l}\text { Asalto y clausura tumultuaria de } \\
\text { dos colegios religiosos. }\end{array}$ & Desconocido & $\begin{array}{l}\text { Nunz. C. } 925, \text { F. } 1 \\
D S C, 4-\text { II-36 }\end{array}$ \\
\hline $\begin{array}{l}\text { Alcalá de } \\
\text { Henares }\end{array}$ & $20-2-36$ & $\begin{array}{l}\text { Asalto y saqueo de un centro } \\
\text { de Acción Católica. Junto } \\
\text { con la sede de AP. Quema del } \\
\text { mobiliario. Apedreamiento de un } \\
\text { domicilio particular. }\end{array}$ & Desconocido & $\begin{array}{l}\text { Nunz. C. } 945 \\
\text { DSC, } 15-\mathrm{IV}-1936\end{array}$ \\
\hline $\begin{array}{l}\text { Alcalá de } \\
\text { Henares }\end{array}$ & $\begin{array}{c}4 y \\
5-3-36\end{array}$ & $\begin{array}{l}\text { Incendio parcial de dos iglesias } \\
\text { y un convento. Quema de } \\
\text { imágenes, mobiliario y objetos de } \\
\text { culto. Conatos de incendio en dos } \\
\text { conventos. Tiene lugar junto al } \\
\text { de dos domicilios, dos quioscos } \\
\text { y un taxi. }\end{array}$ & Desconocido & $\begin{array}{l}\text { Nunz. C. } 945, \text { F. } 3 \\
\text { P-S Madrid } \\
\text { L.1536 y } 152\end{array}$ \\
\hline Aranjuez & $5-36$ & $\begin{array}{l}\text { Asalto y clausura de un colegio } \\
\text { religioso. }\end{array}$ & Desconocido & \begin{tabular}{|l|} 
Nunz. C. 925, F. 1 \\
$D S C, 4-V I-36$ \\
\end{tabular} \\
\hline Aravaca & $10-5-36$ & $\begin{array}{l}\text { Asalto de una iglesia durante una } \\
\text { misa. Apedreamiento del cura que } \\
\text { tuvo que huir. Destrozo de objetos } \\
\text { de culto. }\end{array}$ & Desconocido & Nunz. C. 925 , F. 1 \\
\hline $\begin{array}{l}\text { Buitrago del } \\
\text { Lozoya }\end{array}$ & $14-3-36$ & $\begin{array}{l}\text { Incendio de la iglesia con graves } \\
\text { daños. Quema de imágenes. }\end{array}$ & Desconocido & $\begin{array}{l}\text { Nunz. C. } 945, \text { F. } 3 \\
\text { P-S Madrid L. } 152 \\
\text { DSC, 15-IV-1936 } \\
\end{array}$ \\
\hline Canillas & $5-36$ & $\begin{array}{l}\text { Asalto y clausura tumultuaria de } \\
\text { cuatro colegios religiosos. }\end{array}$ & Desconocido & \begin{tabular}{|l|} 
Nunz. C. 925, F. 1 \\
$D S C, 4-$ VI-36 \\
\end{tabular} \\
\hline $\begin{array}{l}\text { Carabanchel } \\
\text { Bajo }\end{array}$ & $17-2-36$ & $\begin{array}{l}\text { Incendio de una iglesia con graves } \\
\text { daños. }\end{array}$ & Desconocido & $\begin{array}{l}\text { P-S Madrid L. } \\
152\end{array}$ \\
\hline $\begin{array}{l}\text { Carabanchel } \\
\text { Bajo }\end{array}$ & $5-36$ & $\begin{array}{l}\text { Asalto y clausura de cuatro } \\
\text { colegios religiosos. Incendio } \\
\text { parcial de todos ellos. }\end{array}$ & $\begin{array}{l}\text { "Guardia } \\
\text { Roja" }\end{array}$ & $\begin{array}{l}\text { Nunz. C. } 925, \text { F. } 1 \\
D S C, 4-V I-36\end{array}$ \\
\hline $\begin{array}{l}\text { Chamartín de } \\
\text { la Rosa }\end{array}$ & $5-36$ & $\begin{array}{l}\text { Asalto y clausura de ocho colegios } \\
\text { religiosos. Incendio parcial en } \\
\text { "algunos de ellos" (al menos dos). }\end{array}$ & "Guardia & $\begin{array}{l}\text { Nunz. C. } 925, \text { F. } 1 \\
D S C, 4-\text { VI-36 }\end{array}$ \\
\hline
\end{tabular}




\begin{tabular}{|c|c|c|c|c|}
\hline $\begin{array}{l}\text { Provincia y } \\
\text { Localidad }\end{array}$ & Fecha & Tipo de Violencia & Autoría & Fuente \\
\hline Ciempozuelos & $8-5-36$ & $\begin{array}{l}\text { Incendio de la iglesia con graves } \\
\text { daños. }\end{array}$ & Desconocido & $\begin{array}{l}\text { Nunz. C. } 925, \text { F. } 1 \\
\text { P-S Madrid L. } \\
2376 \\
\end{array}$ \\
\hline Ciempozuelos & $5-36$ & $\begin{array}{l}\begin{array}{l}\text { Asalto y clausura tumultuaria de } \\
\text { cuatro colegios religiosos. }\end{array} \\
\end{array}$ & Desconocido & \begin{tabular}{|l|} 
Nunz. C. 925, F. 1 \\
$D S C, 4-$ VI- 36 \\
\end{tabular} \\
\hline Fuencarral & $10-5-36$ & Asalto y saqueo de una iglesia. & Desconocido & Nunz. C. 925 , F. 1 \\
\hline Getafe & $16-4-36$ & $\begin{array}{l}\text { Asalto y saqueo de un convento. } \\
\text { Quema del mobiliario. }\end{array}$ & Desconocido & $\begin{array}{l}\text { P-S Madrid L. } \\
152\end{array}$ \\
\hline $\begin{array}{l}\text { Mejorada del } \\
\text { Campo }\end{array}$ & $5-36$ & $\begin{array}{l}\begin{array}{l}\text { Asalto y clausura tumultuaria de } \\
\text { dos colegios religiosos. }\end{array} \\
\end{array}$ & Desconocido & \begin{tabular}{|l|} 
Nunz. C. 925, F. 1 \\
$D S C, 4-$ VI- 36 \\
\end{tabular} \\
\hline $\begin{array}{l}\text { Rozas de } \\
\text { Puerto Real }\end{array}$ & $3-36$ & Asalto de la casa rectoral. & Comunistas & Nunz. C. 945 , F. 3 \\
\hline Vicálvaro & $5-36$ & $\begin{array}{l}\text { Asalto y clausura tumultuaria de } \\
\text { un colegio religioso. }\end{array}$ & Desconocido & $\begin{array}{l}925, \text { F. } 1 \\
\mathrm{I}-36\end{array}$ \\
\hline Villaverde & $11-5-36$ & $\begin{array}{l}\text { Asalto de un convento. Conato de } \\
\text { expulsión de unas religiosas. }\end{array}$ & Desconocido & Nunz. C. 925 , F. 1 \\
\hline a de & $17-5-36$ & $\begin{array}{l}\text { Asalto y saqueo de una ermita. } \\
\text { Destrozo de las imágenes. }\end{array}$ & Desconocido & Nunz. C. 925, F. 1 \\
\hline \multicolumn{5}{|c|}{ MÁLAGA } \\
\hline $\begin{array}{l}\text { Málaga } \\
\text { (Campanillas) }\end{array}$ & $23-2-36$ & Asalto y saqueo de una iglesia. & Desconocido & $\begin{array}{l}\text { P-S Madrid L. } 152 \\
\text { Nunz. C. } 912 \\
\text { DSC, 15-IV-1936 } \\
\end{array}$ \\
\hline $\begin{array}{l}\text { Málaga } \\
\text { (Campanillas) }\end{array}$ & $10-3-36$ & $\begin{array}{l}\text { Asalto, saqueo y ocupación de la } \\
\text { iglesia. Robo de imágenes. }\end{array}$ & Desconocido & $\begin{array}{l}\text { Nunz. C. } 945, \text { F. } 3 \\
\text { La Vanguardia, } \\
11-3-36 \\
\text { DSC, } 15-\mathrm{IV}-1936 \\
\end{array}$ \\
\hline $\begin{array}{l}\text { Málaga } \\
\text { (Campanillas) }\end{array}$ & $18-3-36$ & Incendio parcial de la iglesia. & Desconocido & $\begin{array}{l}\text { Nunz. C. } 945, \text { F. } 3 \\
\text { P-S Madrid L. } 152 \\
\text { DSC, 15-IV-1936 } \\
\end{array}$ \\
\hline Álora & $\begin{array}{c}11 \mathrm{y} \\
12-5-36\end{array}$ & $\begin{array}{l}\text { Asalto, saqueo y ocupación de } \\
\text { dos iglesias, un convento y una } \\
\text { ermita. Destrozo de imágenes y } \\
\text { objetos de culto. }\end{array}$ & $\begin{array}{l}\text { Socialistas y } \\
\text { comunistas }\end{array}$ & $\begin{array}{l}\text { Nunz. C. } 925, \text { F. } 1 \\
\text { P-S Madrid L. } \\
2376\end{array}$ \\
\hline Antequera & $23-2-36$ & $\begin{array}{l}\text { Asalto, saqueo y ocupación de una } \\
\text { iglesia. Robo de las imágenes. } \\
\end{array}$ & Socialistas & \begin{tabular}{|l|} 
P-S Madrid L. 152 \\
Nunz. C. 912 \\
\end{tabular} \\
\hline Antequera & $15-3-36$ & $\begin{array}{l}\text { Destrucción de capillas y hornacinas } \\
\text { de significación religiosa. Tiene } \\
\text { lugar junto a un conato de asalto al } \\
\text { Instituto de Secundaria. }\end{array}$ & Desconocido & \begin{tabular}{|l|} 
Nunz. C. 925 \\
P-S Madrid L. \\
152 \\
DSC, $15-\mathrm{IV}-1936$ \\
\end{tabular} \\
\hline $\begin{array}{l}\text { Antequera } \\
\text { (Bobadilla) }\end{array}$ & $23-2-36$ & $\begin{array}{l}\text { Asalto y saqueo de dos iglesias y } \\
\text { la casa rectoral. }\end{array}$ & Socialistas & $\begin{array}{l}\text { Nunz. C. } 945 \text {, F. } 3 \\
\text { P-S Madrid } \\
\text { L.1536 }\end{array}$ \\
\hline
\end{tabular}




\begin{tabular}{|c|c|c|c|c|}
\hline $\begin{array}{l}\text { Provincia y } \\
\text { Localidad }\end{array}$ & Fecha & Tipo de Violencia & Autoría & Fuente \\
\hline Archidona & $18-5-36$ & $\begin{array}{l}\text { Asalto y ocupación de un colegio } \\
\text { religioso. }\end{array}$ & Desconocido & $\begin{array}{l}\text { P-S Madrid L. } \\
2377\end{array}$ \\
\hline Arriate & $26-4-36$ & $\begin{array}{l}\text { Asalto y saqueo de la iglesia. } \\
\text { Destrozo del mobiliario. }\end{array}$ & Socialistas & $\begin{array}{l}\text { Nunz. C. 925, F. } 1 \\
\text { P-S Madrid L. } \\
2377 \\
\text { DSC, 7-V-1936 } \\
\end{array}$ \\
\hline Benagalbón & $26-4-36$ & $\begin{array}{l}\text { Asalto de la iglesia y derribo de } \\
\text { las campanas. }\end{array}$ & Desconocido & $\begin{array}{l}\text { Nunz. C. 925, F. } 1 \\
\text { P-S Madrid L. } \\
2377\end{array}$ \\
\hline $\begin{array}{l}\text { Benamar- } \\
\text { gosa }\end{array}$ & $15-5-36$ & Asalto y ocupación de la iglesia. & Comunistas & $\begin{array}{l}\text { Nunz. C. 925, F. } 1 \\
\text { P-S Madrid L. } \\
2376 \\
\end{array}$ \\
\hline Benaoján & $20-2-36$ & $\begin{array}{l}\text { Incendio de la iglesia con graves } \\
\text { daños. }\end{array}$ & Desconocido & $\begin{array}{l}\text { Nunz. C. 945, F. } 3 \\
\text { P-S Madrid L. } \\
152\end{array}$ \\
\hline Borge & $22-3-36$ & Asalto y ocupación de la iglesia. & Socialistas & $\begin{array}{l}\text { P-S Madrid } \\
\text { L.1536 }\end{array}$ \\
\hline $\begin{array}{l}\begin{array}{l}\text { Casarabo- } \\
\text { nela }\end{array} \\
\end{array}$ & $21-2-36$ & $\begin{array}{l}\text { Conato de asalto de la casa } \\
\text { rectoral. }\end{array}$ & Desconocido & Nunz. C. 945 , F. 3 \\
\hline $\begin{array}{l}\text { Casarabo- } \\
\text { nela }\end{array}$ & $13-5-36$ & $\begin{array}{l}\text { Asalto y saqueo de una iglesia } \\
\text { y una ermita. Destrozo del } \\
\text { mobiliario. Conato de asalto a la } \\
\text { casa rectoral. }\end{array}$ & $\begin{array}{l}\text { Comunistas y } \\
\text { anarquistas }\end{array}$ & $\begin{array}{l}\text { Nunz. C. } 925 \text {, F. } 1 \\
\text { P-S Madrid L. } \\
2376\end{array}$ \\
\hline Casares & $20-2-36$ & $\begin{array}{l}\text { Asalto y saqueo de una ermita. } \\
\text { Destrozo de imágenes. }\end{array}$ & Desconocido & Nunz. C. 945 , F. 3 \\
\hline $\begin{array}{l}\text { Cortes de la } \\
\text { Frontera (La } \\
\text { Salceda) }\end{array}$ & $29-4-36$ & $\begin{array}{l}\text { Incendio de una ermita con graves } \\
\text { daños. }\end{array}$ & Desconocido & $\begin{array}{l}\text { P-S Madrid L. } \\
2377\end{array}$ \\
\hline El Burgo & $19-3-36$ & Golpean al párroco de la localidad. & $\begin{array}{c}\text { "Miembros } \\
\text { del centro } \\
\text { obrero" }\end{array}$ & Nunz. C. 945 , F. 3 \\
\hline El Burgo & $16-5-36$ & $\begin{array}{l}\text { Asalto y saqueo de una iglesia. } \\
\text { Destrozo del mobiliario. }\end{array}$ & Desconocido & Nunz. C. 925, F. 1 \\
\hline Estepona & $20-2-36$ & $\begin{array}{l}\text { Incendio parcial de la iglesia. } \\
\text { Destrozo de las imágenes. Incendio } \\
\text { de una ermita con graves daños. }\end{array}$ & Desconocido & Nunz. C. 945 , F. 3 \\
\hline Estepona & $30-4-36$ & $\begin{array}{l}\text { Incendio de dos iglesias y una casa } \\
\text { rectoral, todas con graves daños. }\end{array}$ & Desconocido & $\begin{array}{l}\text { Nunz. C. 925, F. } 1 \\
\text { P-S Madrid L. } \\
2377 \\
\text { DSC, 7-V-1936 } \\
\end{array}$ \\
\hline $\begin{array}{l}\text { Fuente de } \\
\text { Piedra }\end{array}$ & $13-5-36$ & $\begin{array}{l}\text { Asalto y saqueo de la iglesia. } \\
\text { Destrozo del mobiliario. }\end{array}$ & $\begin{array}{l}\text { Juventud } \\
\text { Socialista }\end{array}$ & $\begin{array}{l}\text { Nunz. C. 925, F. } 1 \\
\text { P-S Madrid L. } \\
2376\end{array}$ \\
\hline
\end{tabular}




\begin{tabular}{|c|c|c|c|c|}
\hline $\begin{array}{l}\text { Provincia y } \\
\text { Localidad }\end{array}$ & Fecha & Tipo de Violencia & Autoría & Fuente \\
\hline Genalguacil & $1-5-36$ & $\begin{array}{l}\text { Asalto y saqueo de la iglesia. } \\
\text { Quema de imágenes. }\end{array}$ & Desconocido & P-S Madrid 2377 \\
\hline Guaro & $18-3-36$ & $\begin{array}{l}\text { Asalto y saqueo de la iglesia. } \\
\text { Destrucción las imágenes. }\end{array}$ & Socialistas & $\begin{array}{l}\text { Nunz. C. } 945 \text {, F. } 3 \\
\text { P-S Madrid } \\
\text { L.1536 } \\
\end{array}$ \\
\hline Marbella & $3-3-36$ & $\begin{array}{l}\text { Asalto y saqueo de la iglesia. } \\
\text { Conato de quema de imágenes. }\end{array}$ & Desconocido & $\begin{array}{l}\text { P-S Madrid L. } 152 \\
\text { Nunz. C. } 912 \\
\text { DSC, 15-IV-1936 }\end{array}$ \\
\hline Melilla & $20-2-36$ & $\begin{array}{l}\text { Conato de incendio en una iglesia. } \\
\text { Junto al asalto de las sedes del } \\
\text { Partido Radical y AP. }\end{array}$ & Desconocido & $\begin{array}{l}\text { Nunz. C. } 945, \text { F. } 3 \\
\text { P-S Madrid } \\
\text { L.1536 y } 152 \\
\text { DSC, } 15 \text {-IV-1936 } \\
\end{array}$ \\
\hline Montejaque & $20-2-36$ & $\begin{array}{l}\text { Incendio de la iglesia con graves } \\
\text { daños. }\end{array}$ & Desconocido & \begin{tabular}{|l|} 
Nunz. C. 945, F. 3 \\
P-S Madrid L. 152 \\
\end{tabular} \\
\hline Ojén & $4-3-36$ & Conato de incendio de la iglesia. & Desconocido & $\begin{array}{l}\text { La Vanguardia, } \\
\text { 5-III-1936 }\end{array}$ \\
\hline Ojén & $22-3-36$ & Asalto y ocupación de la iglesia. & $\begin{array}{l}\text { Juventud } \\
\text { Socialista }\end{array}$ & $\begin{array}{l}\text { Nunz. C. } 945 \text {, F. } 3 \\
\text { P-S Madrid } \\
\text { L.1536 } \\
\end{array}$ \\
\hline Ojén & $15-5-36$ & Asalto y saqueo de la iglesia. & $\begin{array}{l}\text { Juventud } \\
\text { Socialista }\end{array}$ & $\begin{array}{l}\text { Nunz. C. } 925, \text { F. } 1 \\
\text { P-S Madrid L. } \\
2376\end{array}$ \\
\hline Pizarra & $13-5-36$ & \begin{tabular}{|l|} 
Asalto y saqueo de la iglesia. \\
Conato de incendio del mobiliario.
\end{tabular} & Desconocido & $\begin{array}{l}\text { P-S Madrid L. } \\
2376\end{array}$ \\
\hline $\begin{array}{l}\text { Ronda (La } \\
\text { Cimada) }\end{array}$ & $23-4-36$ & $\begin{array}{l}\text { Asalto y saqueo de una ermita. } \\
\text { Quema de imágenes y objetos de } \\
\text { culto. }\end{array}$ & Desconocido & $\begin{array}{l}\text { P-S Madrid L. } \\
2377 \\
\text { DSC }, 7-\mathrm{V}-1936 \\
\end{array}$ \\
\hline $\begin{array}{l}\text { Ronda } \\
\text { (Montecorto) }\end{array}$ & $23-4-36$ & $\begin{array}{l}\text { Asalto y saqueo de la iglesia. } \\
\text { Quema de imágenes y objetos de } \\
\text { culto. }\end{array}$ & Desconocido & $\begin{array}{l}\text { P-S Madrid L. } \\
2377 \\
\text { DSC, } 7-\mathrm{V}-1936 \\
\end{array}$ \\
\hline Vélez Málaga & $19-3-36$ & $\begin{array}{l}\text { Asalto y saqueo de dos iglesias y } \\
\text { un convento. }\end{array}$ & Desconocido & \begin{tabular}{|l|} 
Nunz. C. 945, F. 3 \\
P-S Madrid L. 152 \\
\end{tabular} \\
\hline $\begin{array}{l}\text { Vélez Málaga } \\
\text { (Torre del } \\
\text { Mar) } \\
\end{array}$ & $19-3-36$ & $\begin{array}{l}\text { Asalto y saqueo de la iglesia. } \\
\text { Conato de incendio de las } \\
\text { imágenes. }\end{array}$ & Desconocido & $\begin{array}{l}\text { Nunz. C. } 945 \text {, F. } 3 \\
\text { P-S Madrid } \\
\text { L.1536 y } 152 \\
\end{array}$ \\
\hline $\begin{array}{l}\text { Vélez Málaga } \\
\text { (Almayate) }\end{array}$ & $20-3-36$ & $\begin{array}{l}\text { Asalto y saqueo de una ermita. } \\
\text { Destrozo de las imágenes. }\end{array}$ & Desconocido & $\begin{array}{l}\text { Nunz. C. } 945, \text { F. } 3 \\
\text { P-S Madrid } \\
\text { L. } 1536\end{array}$ \\
\hline $\begin{array}{l}\text { Villanueva de } \\
\text { Algaidas }\end{array}$ & $27-4-36$ & $\begin{array}{l}\text { Disparan contra el cura durante un } \\
\text { entierro. El sacerdote tiene que huir. }\end{array}$ & Desconocido & Nunz. C. 925, F. 1 \\
\hline $\begin{array}{l}\text { Villanueva de } \\
\text { la Concepción }\end{array}$ & $25-3-36$ & $\begin{array}{l}\text { Asalto y saqueo de la iglesia. } \\
\text { Quema de imágenes. Robo de } \\
\text { objetos de culto. }\end{array}$ & Desconocido & $\begin{array}{l}\text { Nunz. C. } 945, \text { F. } 3 \\
\text { P-S Madrid } \\
\text { L.1536 y } 152 \\
\end{array}$ \\
\hline
\end{tabular}




\begin{tabular}{|c|c|c|c|c|}
\hline $\begin{array}{l}\text { Provincia y } \\
\text { Localidad }\end{array}$ & Fecha & Tipo de Violencia & Autoría & Fuente \\
\hline $\begin{array}{l}\text { Villanueva del } \\
\text { Trabuco }\end{array}$ & $5-36$ & $\begin{array}{l}\text { Incendian un coche del cura. } \\
\text { Acto continuo, el sacerdote es } \\
\text { expulsado del pueblo. }\end{array}$ & Desconocido & Nunz. C. 925 , F. 1 \\
\hline Yunquera & $15-5-36$ & $\begin{array}{l}\text { Asalto y saqueo de una iglesia. } \\
\text { Destrozo del mobiliario. }\end{array}$ & $\begin{array}{l}\text { Juventud } \\
\text { Socialista }\end{array}$ & $\begin{array}{l}\text { Nunz. C. 925, F. } 1 \\
\text { P-S Madrid L. } \\
2376 \\
\end{array}$ \\
\hline \multicolumn{5}{|c|}{ MURCIA } \\
\hline Murcia & $20-2-36$ & $\begin{array}{l}\text { Conato de incendio en una iglesia } \\
\text { y una casa rectoral. Tiene lugar } \\
\text { junto al asalto de las sedes de AP } \\
\text { y tradicionalista, dos periódicos de } \\
\text { derecha y un bar. }\end{array}$ & Desconocido & $\begin{array}{l}\text { Nunz. C. } 945 \text { y } \\
912 \\
\text { P-S Madrid L. } \\
152 \\
\text { DSC, } 15-\mathrm{IV}-1936 \\
\end{array}$ \\
\hline Murcia & $5-4-36$ & Incendio parcial de una iglesia. & Desconocido & $\begin{array}{l}\text { P-S Madrid L. } 152 \\
\text { DSC, 7-V-1936 }\end{array}$ \\
\hline Abarán & $28-5-36$ & $\begin{array}{l}\text { Asalto y saqueo de una ermita. } \\
\text { Destrozo de imágenes. }\end{array}$ & Desconocido & Nunz. C. 925, F. 1 \\
\hline Alcantarilla & $18-2-36$ & $\begin{array}{l}\text { Asalto y saqueo de una iglesia. } \\
\text { Destrozo de imágenes. }\end{array}$ & Desconocido & $\begin{array}{l}\text { P-S Madrid } \\
\text { L.1536 } \\
\end{array}$ \\
\hline Avileses & $3-36$ & Incendio parcial de la iglesia. & Desconocido & $\begin{array}{l}\text { Nunz. C. } 945, \text { F. } 3 \\
\text { P-S Madrid } \\
\text { L.1536 } \\
\end{array}$ \\
\hline Beniaján & $20-2-36$ & Incendio parcial de la iglesia. & Desconocido & $\begin{array}{l}\text { Nunz. C. } 945, \text { F. } 3 \\
\text { P-S Madrid } \\
\text { L.1536 } \\
\end{array}$ \\
\hline Beniaján & $13-3-36$ & $\begin{array}{l}\text { Incendio de la iglesia con graves } \\
\text { daños. Quema de imágenes. }\end{array}$ & Desconocido & $\begin{array}{l}\text { P-S Madrid L. } 152 \\
\text { Nunz. C. } 945 \\
\text { DSC, 15-IV-1936 } \\
\end{array}$ \\
\hline Beniaján & $15-3-36$ & $\begin{array}{l}\text { Incendio parcial de dos ermitas. } \\
\text { Asalto y saqueo del archivo } \\
\text { parroquial. }\end{array}$ & Desconocido & $\begin{array}{l}\text { Nunz. C. } 945, \text { F. } 3 \\
D S C, 15-I V-1936\end{array}$ \\
\hline Calasparra & $8-5-36$ & $\begin{array}{l}\text { Incendio parcial de la iglesia. } \\
\text { Quema de imágenes y objetos de } \\
\text { culto. Tapiado de las puertas de } \\
\text { dos ermitas. }\end{array}$ & Desconocido & $\begin{array}{l}\text { Nunz. C. } 925, \text { F. } 1 \\
\text { P-S Madrid L. } \\
2376\end{array}$ \\
\hline Campillo & $3-36$ & $\begin{array}{l}\text { Asalto y saqueo de una iglesia. } \\
\text { Quema de imágenes y objetos de } \\
\text { culto. }\end{array}$ & Desconocido & Nunz. C. 945 , F. 3 \\
\hline Cartagena & $20-2-36$ & $\begin{array}{l}\text { Conato de incendio en una iglesia. } \\
\text { Tiene lugar junto al incendio de } \\
\text { una sede de AP. }\end{array}$ & Desconocido & $\begin{array}{l}\text { P-S Madrid L. } 152 \\
\text { Nunz. C. } 912 \\
\text { DSC, } 15-\mathrm{IV}-1936 \\
\end{array}$ \\
\hline
\end{tabular}




\begin{tabular}{|c|c|c|c|c|}
\hline $\begin{array}{l}\text { Provincia y } \\
\text { Localidad }\end{array}$ & Fecha & Tipo de Violencia & Autoría & Fuente \\
\hline Cehegín & $9-3-36$ & $\begin{array}{l}\text { Incendio de una iglesia y la casa } \\
\text { rectoral con graves daños. }\end{array}$ & Socialistas & $\begin{array}{l}\text { Nunz. C. } 945, \text { F. } 3 \\
\text { P-S Madrid } \\
\text { L.1536 y } 152 \\
\text { DSC, } 15-\text { IV-1936 } \\
\end{array}$ \\
\hline Cehegín & $11-3-36$ & $\begin{array}{l}\text { Incendio de tres ermitas con } \\
\text { graves daños. Incendio parcial de } \\
\text { una iglesia. Tiene lugar junto al } \\
\text { incendio de la sede de AP. } \\
\end{array}$ & Desconocido & $\begin{array}{l}\text { Nunz. C. } 945, \text { F. } 3 \\
\text { P-S Madrid } \\
\text { L.1536 y } 152 \\
\text { DSC, } 15-I V-1936 \\
\end{array}$ \\
\hline $\begin{array}{l}\text { Cehegín } \\
\text { (Valentín) }\end{array}$ & $3-36$ & $\begin{array}{l}\text { Asalto y saqueo de la iglesia y la } \\
\text { casa rectoral. Quema de objetos } \\
\text { de culto. }\end{array}$ & Desconocido & $\begin{array}{l}\text { Nunz. C. } 945, \text { F. } 3 \\
\text { P-S Madrid } \\
\text { L.1536 }\end{array}$ \\
\hline $\begin{array}{l}\text { Cehegín } \\
\text { (Burete) }\end{array}$ & $11-3-36$ & $\begin{array}{l}\text { Incendio en la iglesia con graves } \\
\text { daños. Destrozo de imágenes y } \\
\text { objetos de culto. }\end{array}$ & Desconocido & $\begin{array}{l}\text { Nunz. C. 945, F. } 3 \\
\text { P-S Madrid } \\
\text { L.1536 } \\
\end{array}$ \\
\hline $\begin{array}{l}\text { Cehegín } \\
\text { (Escobar) }\end{array}$ & $3-36$ & Asalto y saqueo de la iglesia. & Desconocido & \begin{tabular}{|l} 
Nunz. C. 945, F. 3 \\
P-S Madrid \\
L.1536 \\
\end{tabular} \\
\hline Esparragal & $3-36$ & $\begin{array}{l}\text { Asalto y saqueo de una iglesia. } \\
\text { Quema de imágenes y objetos de } \\
\text { culto. }\end{array}$ & Desconocido & Nunz. C. 945 , F. 3 \\
\hline Los Alcázares & $15-3-36$ & $\begin{array}{l}\text { Incendio de una ermita con graves } \\
\text { daños. Quema de imágenes. }\end{array}$ & Desconocido & \begin{tabular}{|l} 
Nunz. C. 925, F. 1 \\
P-S Madrid L. 152 \\
DSC, 15-IV-1936
\end{tabular} \\
\hline Los Garres & $15-3-36$ & $\begin{array}{l}\text { Incendio parcial de la iglesia. Asalto } \\
\text { y saqueo de dos ermitas. Quema de } \\
\text { imágenes y objetos de culto. }\end{array}$ & Desconocido & $\begin{array}{l}\text { Nunz. C. } 945, \text { F. } 3 \\
\text { P-S Madrid L. } 152 \\
\text { DSC, } 15-I V-1936\end{array}$ \\
\hline Monteagudo & $17-3-36$ & $\begin{array}{l}\text { Asalto y saqueo de una iglesia. } \\
\text { Quema de imágenes y objetos de } \\
\text { culto. }\end{array}$ & Desconocido & \begin{tabular}{|l} 
Nunz. C. 945, F. 3 \\
P-S Madrid L. 152 \\
DSC, 15-IV-1936 \\
\end{tabular} \\
\hline Moratalla & $11-5-36$ & $\begin{array}{l}\text { Asalto y saqueo de una ermita. } \\
\text { Destrucción de imágenes y objetos } \\
\text { de culto. }\end{array}$ & Desconocido & $\begin{array}{l}\text { Nunz. C. 925, F. } 1 \\
\text { P-S Madrid L. } \\
2376 \\
\end{array}$ \\
\hline Peña & $3-36$ & $\begin{array}{l}\text { Incendio parcial de la iglesia y } \\
\text { casa rectoral. }\end{array}$ & Desconocido & \begin{tabular}{|l|} 
Nunz. C. 945, F. 3 \\
P-S Madrid \\
L.1536 \\
\end{tabular} \\
\hline $\begin{array}{l}\text { Puente } \\
\text { Tocinos }\end{array}$ & $15-3-36$ & \begin{tabular}{|l|} 
Incendio de una iglesia y una \\
ermita con graves daños. Quema \\
de imágenes. Asalto y saqueo de la \\
casa rectoral.
\end{tabular} & Desconocido & $\begin{array}{l}\text { Nunz. C. 945, F. } 3 \\
\text { P-S Madrid L. } \\
152 \\
\text { DSC, 15-IV-1936 }\end{array}$ \\
\hline $\begin{array}{l}\text { San Pedro } \\
\text { de Pinatar } \\
\text { (Cañada) }\end{array}$ & $3-36$ & $\begin{array}{l}\text { Incendio de la iglesia y de la } \\
\text { ermita con graves daños. }\end{array}$ & Desconocido & Nunz. C. 945 , F. 3 \\
\hline
\end{tabular}




\begin{tabular}{|c|c|c|c|c|}
\hline $\begin{array}{l}\text { Provincia y } \\
\text { Localidad }\end{array}$ & Fecha & Tipo de Violencia & Autoría & Fuente \\
\hline Torreagüera & $20-2-36$ & $\begin{array}{l}\text { Asalto y saqueo de la iglesia. } \\
\text { Quema de las imágenes y objetos } \\
\text { de culto. }\end{array}$ & Desconocido & $\begin{array}{l}\text { Nunz. C. } 945, \text { F. } 3 \\
\text { P-S Madrid } \\
\text { L.1536 y } 152 \\
D S C, 15-I V-1936\end{array}$ \\
\hline Torreagüera & $14-3-36$ & $\begin{array}{l}\text { Incendio de la iglesia con graves } \\
\text { daños. Destrozo de las imágenes. }\end{array}$ & Desconocido & \begin{tabular}{|l|} 
P-S Madrid L. \\
152 \\
Nunz. C. 945 \\
DSC, $15-\mathrm{IV}-1936$ \\
\end{tabular} \\
\hline Torre Pacheco & $3-36$ & $\begin{array}{l}\text { Asalto y saqueo de una ermita. } \\
\text { Quema de objetos de culto. }\end{array}$ & Desconocido & Nunz. C. 945 , F. 3 \\
\hline Yecla & $14-3-36$ & $\begin{array}{l}\text { Incendio de nueve iglesias, una } \\
\text { casa rectoral, un convento, un } \\
\text { centro de Acción Católica y un } \\
\text { asilo de ancianos con graves } \\
\text { daños. Quema de imágenes y } \\
\text { mobiliario. Tiene lugar junto a la } \\
\text { de varios círculos de labradores, } \\
\text { domicilios particulares y el } \\
\text { registro de la propiedad. }\end{array}$ & Desconocido & $\begin{array}{l}\text { Nunz. C. } 945, \text { F. } 3 \\
\text { P-S Madrid } \\
\text { L.1536 y } 152 \\
\text { DSC, } 7-\mathrm{V}-1936\end{array}$ \\
\hline Yecla & $22-4-36$ & $\begin{array}{l}\text { Asalto y saqueo de una ermita. } \\
\text { Quema de objetos de culto. }\end{array}$ & Desconocido & \begin{tabular}{|l} 
P-S Madrid L. \\
2377 \\
\end{tabular} \\
\hline \multicolumn{5}{|c|}{ NAVARRA } \\
\hline Pamplona & $23-3-36$ & $\begin{array}{l}\text { Apedreamiento del palacio } \\
\text { arzobispal. }\end{array}$ & Desconocido & Nunz. C. 945 \\
\hline Caparroso & $5-36$ & $\begin{array}{l}\text { Asalto y saqueo de una ermita. } \\
\text { Destrozo de imágenes. }\end{array}$ & Desconocido & Nunz. C. 925 , F. 1 \\
\hline Garde & $5-36$ & $\begin{array}{l}\text { Apedreamiento de una iglesia con } \\
\text { rotura de vidrieras. }\end{array}$ & Desconocido & Nunz. C. 925 , F. 1 \\
\hline Ujué & $6-36$ & Destrozo de una cruz monumental. & Desconocido & $\begin{array}{l}\text { Nunz. C. } 925, \text { F. } 1 \\
\text { La Vanguardia, } \\
18-\text { VI-1936 }\end{array}$ \\
\hline \multicolumn{5}{|c|}{ ORENSE } \\
\hline Orense (Velle) & $10-6-36$ & Incendio parcial de la iglesia. & Desconocido & Nunz. C. 925, F. 1 \\
\hline Barbadanes & $3-36$ & $\begin{array}{l}\text { Asalto y saqueo de la iglesia. } \\
\text { Quema de objetos de culto. }\end{array}$ & Desconocido & Nunz. C. 945 , F. 3 \\
\hline Barbadanes & $4-36$ & $\begin{array}{l}\text { Incendio de la iglesia con daños } \\
\text { graves. }\end{array}$ & Desconocido & Nunz. C. 945 , F. 3 \\
\hline $\begin{array}{l}\text { Castrelo de } \\
\text { Abajo }\end{array}$ & $25-3-36$ & $\begin{array}{l}\text { Asalto y saqueo de la iglesia. } \\
\text { Quema de objetos de culto. }\end{array}$ & Desconocido & $\begin{array}{l}\text { Nunz. C. 945, F. } 3 \\
\text { P-S Madrid } \\
\text { L.1536 } \\
\end{array}$ \\
\hline Cudeiro & $3-36$ & $\begin{array}{l}\text { Asalto y ocupación de la casa } \\
\text { rectoral. }\end{array}$ & Desconocido & Nunz. C. 945 , F. 3 \\
\hline
\end{tabular}




\begin{tabular}{|c|c|c|c|c|}
\hline $\begin{array}{c}\text { Provincia y } \\
\text { Localidad }\end{array}$ & Fecha & Tipo de Violencia & Autoría & Fuente \\
\hline $\begin{array}{l}\text { El Barco de } \\
\text { Valdeorras } \\
\text { (Castro) }\end{array}$ & $20-4-36$ & $\begin{array}{l}\text { Incendio de una iglesia con daños } \\
\text { graves. }\end{array}$ & Desconocido & $\begin{array}{l}\text { P-S Madrid L. } \\
2377\end{array}$ \\
\hline Palmés & $25-3-36$ & $\begin{array}{l}\text { Estalla una bomba en la casa } \\
\text { rectoral provocando fuertes } \\
\text { desperfectos. }\end{array}$ & Desconocido & $\begin{array}{l}\text { Nunz. C. 945, F. } 3 \\
\text { P-S Madrid } \\
\text { L.1536 }\end{array}$ \\
\hline $\begin{array}{l}\text { Parada del Sil } \\
\text { (Paradellas) }\end{array}$ & $3-36$ & $\begin{array}{l}\text { Incendio de la iglesia con graves } \\
\text { daños. }\end{array}$ & Desconocido & Nunz. C. 945 , F. 3 \\
\hline $\begin{array}{l}\text { Rúa de } \\
\text { Valdeorras }\end{array}$ & $3-36$ & $\begin{array}{l}\text { Asalto y ocupación de la casa } \\
\text { rectoral. }\end{array}$ & Comunistas & $\begin{array}{l}\text { P-S Madrid } \\
\text { L.1536 } \\
\text { DSC, } 15-\mathrm{IV}-1936 \\
\end{array}$ \\
\hline $\begin{array}{l}\text { San Miguel } \\
\text { de Melias }\end{array}$ & $10-6-36$ & Incendio parcial de la iglesia. & Desconocido & Nunz. C. 925 , F. 1 \\
\hline $\begin{array}{l}\text { Santa Cruz de } \\
\text { Rabeda }\end{array}$ & $10-6-36$ & $\begin{array}{l}\text { Incendio de la iglesia con graves } \\
\text { daños. }\end{array}$ & Desconocido & Nunz. C. 925 , F. 1 \\
\hline $\begin{array}{l}\text { Vilar de } \\
\text { Barrio }\end{array}$ & $3-36$ & $\begin{array}{l}\text { Incendio de la iglesia con graves } \\
\text { daños. }\end{array}$ & Desconocido & Nunz. C. 945 , F. 3 \\
\hline Villardevós & $25-3-36$ & $\begin{array}{l}\text { Asalto y saqueo de la iglesia. } \\
\text { Quema de objetos de culto. }\end{array}$ & Desconocido & $\begin{array}{l}\text { Nunz. C. 945, F. } 3 \\
\text { P-S Madrid } \\
\text { L.1536 } \\
\end{array}$ \\
\hline \multicolumn{5}{|c|}{ OVIEDO } \\
\hline $\begin{array}{l}\text { Oviedo } \\
\text { (Brañes) }\end{array}$ & $6-4-36$ & $\begin{array}{l}\text { Asalto y saqueo de una iglesia. } \\
\text { Destrozo de las imágenes. }\end{array}$ & Desconocido & \begin{tabular}{|l} 
P-S Madrid L. 152 \\
DSC, $7-\mathrm{V}-1936$
\end{tabular} \\
\hline $\begin{array}{l}\text { Aller } \\
\text { (Moreda) }\end{array}$ & $27-4-36$ & $\begin{array}{l}\text { Tirotean al sacerdote. Herido el } \\
\text { joven que lo acompaña. }\end{array}$ & Desconocido & DSC, 7-V-1936 \\
\hline $\begin{array}{l}\text { Carreño } \\
\text { (Albandi) }\end{array}$ & $5-36$ & $\begin{array}{l}\text { Incendio de la iglesia con graves } \\
\text { daños. }\end{array}$ & Desconocido & $A B C, 20-\mathrm{V}-36$ \\
\hline Caso (Bueres) & $6-36$ & $\begin{array}{l}\text { Asalto y ocupación de la casa } \\
\text { rectoral. }\end{array}$ & Desconocido & \begin{tabular}{|l|} 
P-S Barcelona L. \\
164 \\
\end{tabular} \\
\hline $\begin{array}{l}\text { Caso } \\
\text { (Coballes) }\end{array}$ & $6-36$ & $\begin{array}{l}\text { Asalto y ocupación de la casa } \\
\text { rectoral. }\end{array}$ & Desconocido & $\begin{array}{l}\text { P-S Barcelona L. } \\
164\end{array}$ \\
\hline $\begin{array}{l}\text { Caso } \\
\text { (Felguerina) }\end{array}$ & $6-36$ & $\begin{array}{l}\text { Asalto y ocupación de la casa } \\
\text { rectoral. }\end{array}$ & Desconocido & $\begin{array}{l}\text { P-S Barcelona L. } \\
164\end{array}$ \\
\hline Caso (Orle) & $6-36$ & $\begin{array}{l}\text { Asalto y ocupación de la casa } \\
\text { rectoral. }\end{array}$ & Desconocido & \begin{tabular}{|l|} 
P-S Barcelona L. \\
164 \\
\end{tabular} \\
\hline \begin{tabular}{l|} 
Caso \\
Sobrecastiello \\
\end{tabular} & $6-36$ & $\begin{array}{l}\text { Asalto y ocupación de la casa } \\
\text { rectoral. }\end{array}$ & Desconocido & \begin{tabular}{|l|} 
P-S Barcelona L. \\
164 \\
\end{tabular} \\
\hline Caso (Tanes) & $6-36$ & $\begin{array}{l}\text { Asalto y ocupación de la casa } \\
\text { rectoral. }\end{array}$ & Desconocido & \begin{tabular}{|l|} 
P-S Barcelona L. \\
164 \\
\end{tabular} \\
\hline $\begin{array}{l}\text { Gozón } \\
\text { (Bañugués) }\end{array}$ & $8-3-36$ & $\begin{array}{l}\text { Asalto y saqueo del centro de } \\
\text { Acción Católica. Destrucción de } \\
\text { imágenes y mobiliario. }\end{array}$ & Desconocido & $\begin{array}{l}\text { Nunz. C. } 945 \\
D S C, 15-I V-1936\end{array}$ \\
\hline
\end{tabular}




\begin{tabular}{|c|c|c|c|c|}
\hline $\begin{array}{c}\text { Provincia y } \\
\text { Localidad }\end{array}$ & Fecha & Tipo de Violencia & Autoría & Fuente \\
\hline $\begin{array}{l}\text { Gozón } \\
\text { (Bañugués) }\end{array}$ & $17-3-36$ & $\begin{array}{l}\text { Conato de asalto e incendio de la } \\
\text { iglesia. }\end{array}$ & Des & $\begin{array}{l}\text { P-S Madrid L. } \\
152 \\
D S C, 15-I V-1936\end{array}$ \\
\hline Infiesto & $4-4-36$ & $\begin{array}{l}\text { Un sacerdote es herido de bala por } \\
\text { los asaltantes de su casa. }\end{array}$ & $\begin{array}{l}\text { "Guardia } \\
\text { Roja" }\end{array}$ & DSC, 7-V-1936 \\
\hline $\begin{array}{l}\text { Las Regueras } \\
\text { (Valduno) }\end{array}$ & $5-36$ & $\begin{array}{l}\text { Incendio de la iglesia con graves } \\
\text { daños. }\end{array}$ & Desconocido & Nunz. C. 925 , F. 1 \\
\hline $\begin{array}{l}\text { Laviana (La } \\
\text { Braña) }\end{array}$ & $4-36$ & $\begin{array}{l}\text { Asalto y saqueo de la iglesia. } \\
\text { Quema de imágenes. }\end{array}$ & Desconocido & Nunz. C. 945 , F. 3 \\
\hline Laviana & $12-4-36$ & $\begin{array}{l}\text { Incendio parcial de la iglesia. } \\
\text { Quema de objetos de culto. }\end{array}$ & Descon & $\begin{array}{l}\text { Nunz. C. } 925, \text { F. } 1 \\
\text { P-S Madrid L. } 152 \\
D S C, 7-V-1936 \\
\end{array}$ \\
\hline & $4-36$ & & Desconocido & Nunz. C. 945 , F. 3 \\
\hline $\begin{array}{l}\text { Laviana (Pola } \\
\text { de Laviana) }\end{array}$ & $2-4-36$ & $\begin{array}{l}\text { Incendio de la iglesia con graves } \\
\text { daños. }\end{array}$ & Desconocido & 36 \\
\hline & $5-36$ & & Desconocido & Nunz. C. 925, F. 1 \\
\hline Llanera & 436 & $\begin{array}{l}\text { Estallan cartuchos de dinamita y } \\
\text { disparan sobre una casa rectoral. }\end{array}$ & Desconocido & DSC, 7-V-1936 \\
\hline Llanes & $16-4-36$ & $\begin{array}{l}\text { Asalto y saqueo de un centro de } \\
\text { Acción Católica. }\end{array}$ & Comunistas & $D S C, 7-\mathrm{V}-1936$ \\
\hline Mieres & $7-3-36$ & $\begin{array}{l}\text { Incendio de la iglesia con graves } \\
\text { daños. }\end{array}$ & Desconocido & $\begin{array}{l}\text { P-S Madrid L. } 152 \\
\text { DSC, 15-IV-1936 }\end{array}$ \\
\hline $\begin{array}{l}\text { Mieres } \\
\text { (Valdecuna) }\end{array}$ & $15-3-36$ & $\begin{array}{l}\text { Incendio de la iglesia con graves } \\
\text { daños. Quema de imágenes. }\end{array}$ & Desconocido & $\begin{array}{l}\text { Nunz. C. } 945, \text { F. } 3 \\
\text { P-S Madrid L. } 152 \\
D S C, 15-I V-1936\end{array}$ \\
\hline $\begin{array}{l}\text { Mieres } \\
\text { (Valdecuna) }\end{array}$ & $10-4-36$ & $\begin{array}{l}\text { Incendio de una ermita con graves } \\
\text { daños. }\end{array}$ & Desconocido & \begin{tabular}{|l} 
P-S Madrid L. 152 \\
DSC, 7-V-1936
\end{tabular} \\
\hline $\begin{array}{l}\text { Mieres } \\
\text { (Valdecuna) }\end{array}$ & $19-5-36$ & $\begin{array}{l}\text { Incendio de la iglesia con graves } \\
\text { daños. El mismo edificio que se } \\
\text { quemó el } 15 \text { de marzo. }\end{array}$ & Desconocido & $\begin{array}{l}\text { La Vanguardia, } \\
20-\mathrm{V}-1936\end{array}$ \\
\hline $\begin{array}{l}\text { rcín } \\
\text { lego) }\end{array}$ & $5-36$ & $\begin{array}{l}\text { Incendio de la iglesia con graves } \\
\text { daños. }\end{array}$ & Desconocido & Nunz. C. 925 , F. 1 \\
\hline $\begin{array}{l}\text { Navia } \\
\text { (Piñera) }\end{array}$ & $5-36$ & $\begin{array}{l}\text { Incendio de la iglesia con graves } \\
\text { daños. }\end{array}$ & Desconocido & Nunz. C. 925 , F. 1 \\
\hline $\begin{array}{l}\text { Proaza } \\
\text { (Villamejín) }\end{array}$ & $13-4-36$ & $\begin{array}{l}\text { Asalto y saqueo de la iglesia. } \\
\text { Robo de objetos de culto. } \\
\text { Destrozo de imágenes. }\end{array}$ & Desconocido & $\begin{array}{l}\text { P-S Madrid L. } \\
152 \\
\text { DSC }, 7-\mathrm{V}-1936\end{array}$ \\
\hline $\begin{array}{l}\text { Ribadesella } \\
\text { (San Esteban } \\
\text { de Leces) }\end{array}$ & $5-36$ & al de la iglesia. & Desconocido & Nunz. C. 925 , F. 1 \\
\hline
\end{tabular}




\begin{tabular}{|c|c|c|c|c|}
\hline $\begin{array}{l}\text { Provincia y } \\
\text { Localidad }\end{array}$ & Fecha & Tipo de Violencia & Autoría & Fuente \\
\hline $\begin{array}{l}\text { Ribera de } \\
\text { Arriba }\end{array}$ & $6-4-36$ & $\begin{array}{l}\text { Incendio y destrucción de una } \\
\text { ermita. Quema de imágenes. }\end{array}$ & Desconocido & $\begin{array}{l}\text { P-S Madrid L. } 152 \\
\text { DSC, 7-V-1936 }\end{array}$ \\
\hline Riosa & $19-4-36$ & $\begin{array}{l}\text { Asalto y saqueo de la iglesia. } \\
\text { Quema de mobiliario e imágenes. } \\
\text { Conato de incendio en la casa } \\
\text { rectoral. }\end{array}$ & Desconocido & Nunz. C. 912 \\
\hline $\begin{array}{l}\text { San Esteban } \\
\text { de Morcín }\end{array}$ & $5-36$ & $\begin{array}{l}\text { Incendio de la iglesia con graves } \\
\text { daños. }\end{array}$ & Desconocido & Nunz. C. 925 , F. 1 \\
\hline $\begin{array}{l}\text { Siero } \\
\text { (Granda) }\end{array}$ & $5-36$ & $\begin{array}{l}\text { Incendio de la iglesia con graves } \\
\text { daños. }\end{array}$ & Desconocido & Nunz. C. 925 , F. 1 \\
\hline $\begin{array}{l}\text { Siero (Pola de } \\
\text { Siero) }\end{array}$ & $\begin{array}{c}5 y \\
6-36\end{array}$ & $\begin{array}{l}\text { La iglesia ardió parcialmente tras } \\
\text { dos ataques incendiarios. }\end{array}$ & Desconocido & $\begin{array}{l}\text { La Vanguardia, } \\
\text { 26-VI-1936 }\end{array}$ \\
\hline \multicolumn{5}{|c|}{ PONTEVEDRA } \\
\hline Cambados & $3-5-36$ & \begin{tabular}{|l|} 
Destrozo de todas las cruces \\
monumentales (al menos dos).
\end{tabular} & Desconocido & $A B C, 5-\mathrm{V}-1936$ \\
\hline $\begin{array}{l}\text { Dozón (Aldea } \\
\text { de Castro) }\end{array}$ & $7-4-36$ & $\begin{array}{l}\text { Incendio de una iglesia con graves } \\
\text { daños. Quema de imágenes y } \\
\text { objetos de culto. Tiene lugar junto } \\
\text { a un conato de incendio de un } \\
\text { domicilio particular. }\end{array}$ & Desconocido & $\begin{array}{l}\text { P-S Madrid L. } \\
152 \\
D S C, 7-\mathrm{V}-1936\end{array}$ \\
\hline $\begin{array}{l}\text { La Estrada } \\
\text { (Callobre) }\end{array}$ & $1-6-36$ & $\begin{array}{l}\text { Asalto y saqueo de la iglesia. } \\
\text { Quema de imágenes. }\end{array}$ & Desconocido & Nunz. C. 925 , F. 1 \\
\hline Moaña & $9-6-36$ & Incendio parcial de una iglesia. & Desconocido & \begin{tabular}{|l|} 
La Vanguardia, \\
$11-\mathrm{VI}-1936$ \\
\end{tabular} \\
\hline Porriño & $5-36$ & $\begin{array}{l}\text { Incendio de una ermita con daños } \\
\text { graves. }\end{array}$ & Desconocido & Nunz. C. 925 , F. 1 \\
\hline Puenteáreas & $5-5-36$ & $\begin{array}{l}\text { Asalto y saqueo de una ermita. } \\
\text { Quema de imágenes. }\end{array}$ & Desconocido & $\begin{array}{l}\text { La Vanguardia, } \\
\text { 7-V-1936 }\end{array}$ \\
\hline $\begin{array}{l}\text { Tuy (Santa } \\
\text { María de } \\
\text { Áreas) }\end{array}$ & $5-36$ & $\begin{array}{l}\text { Incendio de una ermita con graves } \\
\text { daños. }\end{array}$ & Desconocido & Nunz. C. 925 , F. 1 \\
\hline $\begin{array}{l}\text { Vigo } \\
\text { (Lavadores) }\end{array}$ & $3-3-36$ & $\begin{array}{l}\text { Apedrean e hieren de } \\
\text { consideración al párroco y al } \\
\text { sacristán. }\end{array}$ & Desconocido & $\begin{array}{l}\text { Nunz. C. } 912 \\
D S C, 15-I V-1936\end{array}$ \\
\hline $\begin{array}{l}\text { Vigo } \\
\text { (Comesaña) }\end{array}$ & $19-3-36$ & $\begin{array}{l}\text { Incendio de un local de Acción } \\
\text { Católica. Asalto de una iglesia. } \\
\text { Robo de varios objetos de culto. }\end{array}$ & Desconocido & $\begin{array}{l}\text { Nunz. C. 925, F. } 1 \\
\text { P-S Madrid L. } \\
152 \\
\end{array}$ \\
\hline Vigo & $15-4-36$ & $\begin{array}{l}\text { Conato de asalto al centro de } \\
\text { Acción Católica. }\end{array}$ & Desconocido & DSC, 7-V-1936 \\
\hline $\begin{array}{l}\text { Vilaboa } \\
\text { (Bértola) }\end{array}$ & $4-5-36$ & $\begin{array}{l}\text { Asalto y saqueo de una capilla. } \\
\text { Destrozo de imágenes. }\end{array}$ & Desconocido & Nunz. C. 925 , F. 1 \\
\hline
\end{tabular}




\begin{tabular}{|c|c|c|c|c|}
\hline $\begin{array}{l}\text { Provincia y } \\
\text { Localidad }\end{array}$ & Fecha & Tipo de Violencia & Autoría & Fuente \\
\hline \begin{tabular}{|l|} 
Villagarcía \\
de Arosa \\
(Bamio) \\
\end{tabular} & $5-5-36$ & Incendio parcial de la iglesia. & Desconocido & Nunz. C. 925 , F. 1 \\
\hline \multicolumn{5}{|c|}{ SALAMANCA } \\
\hline Béjar & $\left|\begin{array}{c}19 y \\
20-2-36\end{array}\right|$ & $\begin{array}{l}\text { Asalto y ocupación de una } \\
\text { iglesia. Al día siguiente se } \\
\text { incendia con graves daños. } \\
\text { Destrozo de mobiliario. } \\
\end{array}$ & Desconocido & \begin{tabular}{|l|} 
Nunz. C. 945, F. 3 \\
P-S Madrid L. \\
152 \\
DSC, $15-I V-1936$ \\
\end{tabular} \\
\hline Béjar & 3-6-36 & $\begin{array}{l}\text { Incendio de una ermita con graves } \\
\text { daños. }\end{array}$ & Desconocido & $\begin{array}{l}\text { Nunz. C. } 925, \text { F. } 1 \\
\text { La Vanguardia, } \\
\text { 6-VI-1936 } \\
\end{array}$ \\
\hline Robleda & $15-3-36$ & $\begin{array}{l}\text { Asalto y saqueo de la iglesia. } \\
\text { Robo de objetos de culto. }\end{array}$ & Desconocido & Nunz. C. 945 , F. 3 \\
\hline \begin{tabular}{|l|}
$\begin{array}{l}\text { San Felices de } \\
\text { los Gallegos }\end{array}$ \\
\end{tabular} & $31-5-36$ & $\begin{array}{l}\text { Destrozadas siete cruces de un Vía } \\
\text { Crucis. }\end{array}$ & Desconocido & Nunz. C. 925, F. 1 \\
\hline \multicolumn{5}{|c|}{ TENERIFE } \\
\hline La Laguna & $17-5-36$ & \begin{tabular}{|l|} 
Asalto del Palacio Episcopal y \\
robo de dinero. Asalto y ocupación \\
del Seminario. Conato de asalto a \\
tres conventos y un colegio. \\
\end{tabular} & Desconocido & $\begin{array}{l}\text { Nunz. C. } 925, \text { F. } 1 \\
\text { P-S Madrid L. } \\
4550\end{array}$ \\
\hline La Orotava & $9-5-36$ & $\begin{array}{l}\text { Asalto y conato de incendio de } \\
\text { una ermita. }\end{array}$ & Desconocido & $\begin{array}{l}\text { P-S Madrid L. } \\
4550\end{array}$ \\
\hline \multicolumn{5}{|c|}{ SANTANDER } \\
\hline Santander & $8-4-36$ & $\begin{array}{l}\text { Se lanza una botella de líquido } \\
\text { inflamable contra un convento. }\end{array}$ & Desconocido & DSC, 7-V-1936 \\
\hline Santander & $20-4-36$ & $\begin{array}{l}\text { Incendio del centro de Acción } \\
\text { Católica con graves daños. Tiene } \\
\text { lugar junto al del Casino de Recreo. }\end{array}$ & Desconocido & Nunz. C. 912 \\
\hline Santander & $28-4-36$ & Conato de asalto a una iglesia. & Desconocido & $\begin{array}{l}\text { La Vanguardia, } \\
\text { 30-IV-1936 }\end{array}$ \\
\hline Barreda & $17-2-36$ & $\begin{array}{l}\text { Incendio de la iglesia con graves } \\
\text { daños. }\end{array}$ & Desconocido & \begin{tabular}{|l|} 
Nunz. C. 945, F. 3 \\
P-S Madrid L. 152 \\
\end{tabular} \\
\hline Cartes & $17-4-36$ & $\begin{array}{l}\text { Incendio de la iglesia con graves } \\
\text { daños. }\end{array}$ & Desconocido & $\begin{array}{l}\text { P-S Madrid L. } 152 \\
\text { P-S Madrid L. } \\
2377 \\
\end{array}$ \\
\hline \begin{tabular}{|l} 
Castro \\
Urdiales
\end{tabular} & $\begin{array}{c}19 y \\
20-3-36\end{array} \mid$ & \begin{tabular}{|l|} 
Conato de asalto a un centro de \\
Acción Católica. Tiene lugar junto \\
a otro intento en la sede de AP. Al \\
día siguiente se asalta y se quema \\
el mobiliario. Estalla una bomba \\
en un periódico.
\end{tabular} & Desconocido & $\begin{array}{l}\text { Nunz. C. } 912 \\
D S C, 15-I V-1936\end{array}$ \\
\hline
\end{tabular}




\begin{tabular}{|c|c|c|c|c|}
\hline $\begin{array}{l}\text { Provincia y } \\
\text { Localidad }\end{array}$ & Fecha & Tipo de Violencia & Autoría & Fuente \\
\hline $\begin{array}{l}\text { Los Corrales } \\
\text { de Buelna } \\
\text { (Somahoz) }\end{array}$ & $5-36$ & $\begin{array}{l}\text { Asalto y saqueo de la iglesia. } \\
\text { Quema de imágenes. }\end{array}$ & Desconocido & Nunz. C. 925 , F. 1 \\
\hline $\begin{array}{l}\text { Miengo } \\
\text { (Cudón) }\end{array}$ & $5-4-36$ & $\begin{array}{l}\text { Incendio de la iglesia con graves } \\
\text { daños. }\end{array}$ & Desconocido & $\begin{array}{l}\text { P-S Madrid L. } \\
152 \\
\text { DSC, 7-V-1936 } \\
\end{array}$ \\
\hline $\begin{array}{l}\text { Piélagos } \\
\text { (Puente Arce) }\end{array}$ & $5-4-36$ & $\begin{array}{l}\text { Incendio de la iglesia con graves } \\
\text { daños. }\end{array}$ & Desconocido & \begin{tabular}{|l|} 
P-S Madrid L. 152 \\
DSC, $7-\mathrm{V}-1936$ \\
\end{tabular} \\
\hline $\begin{array}{l}\text { Piélagos } \\
\text { (Salcedo) }\end{array}$ & $7-5-36$ & $\begin{array}{l}\text { Incendio de la iglesia con graves } \\
\text { daños. }\end{array}$ & Desconocido & Nunz. C. 925 , F. 1 \\
\hline $\begin{array}{l}\text { Piélagos } \\
\text { (Vioño) }\end{array}$ & $7-5-36$ & $\begin{array}{l}\text { Asalto y saqueo de la iglesia. } \\
\text { Quema de imágenes. }\end{array}$ & Desconocido & $\begin{array}{l}\text { Nunz. C. 925, F. } 1 \\
\text { P-S Madrid L. } \\
2376 \\
\end{array}$ \\
\hline $\begin{array}{l}\text { Piélagos } \\
\text { (Zurita) }\end{array}$ & $7-5-36$ & $\begin{array}{l}\text { Incendio de la iglesia con graves } \\
\text { daños. }\end{array}$ & Desconocido & $\begin{array}{l}\text { Nunz. C. } 925, \text { F. } 1 \\
\text { P-S Madrid L. } \\
2376\end{array}$ \\
\hline Polanco & $17-3-36$ & $\begin{array}{l}\text { Incendio de la iglesia con graves } \\
\text { daños. }\end{array}$ & Desconocido & $\begin{array}{l}\text { P-S Madrid L. } 152 \\
\text { Nunz. C. } 945 \\
\text { DSC, } 15 \text {-IV-1936 }\end{array}$ \\
\hline $\begin{array}{l}\text { San Felices } \\
\text { de Buelna } \\
\text { (Llano) }\end{array}$ & $5-36$ & $\begin{array}{l}\text { Incendio de la iglesia con graves } \\
\text { daños. }\end{array}$ & Desconocido & Nunz. C. 925, F. 1 \\
\hline $\begin{array}{l}\text { San Felices de } \\
\text { Buelna (Mata) }\end{array}$ & $5-36$ & $\begin{array}{l}\text { Asaltc } \\
\text { Quem }\end{array}$ & Desconocido & Nunz. C. 925, F. 1 \\
\hline $\begin{array}{l}\text { Suances } \\
\text { (Cortiguera) }\end{array}$ & $7-5-36$ & $\begin{array}{l}\text { Incendio de la iglesia con graves } \\
\text { daños. }\end{array}$ & Desconocido & $\begin{array}{l}\text { Nunz. C. } 925, \text { F. } 1 \\
\text { P-S Madrid L. } \\
2376\end{array}$ \\
\hline $\begin{array}{l}\text { Torrelavega } \\
\text { (Campuzano) }\end{array}$ & $7-5-36$ & $\begin{array}{l}\text { Incendio de la iglesia con graves } \\
\text { daños. }\end{array}$ & Desconocido & $\begin{array}{l}\text { Nunz. C. 925, F. } 1 \\
\text { P-S Madrid L. } \\
2376\end{array}$ \\
\hline $\begin{array}{l}\text { Torrelavega } \\
\text { (Ganzo) }\end{array}$ & $7-5-36$ & $\begin{array}{l}\text { Incendio de la iglesia con graves } \\
\text { daños. }\end{array}$ & Desconocido & $\begin{array}{l}\text { Nunz. C. 925, F. } 1 \\
\text { P-S Madrid L. } \\
2376\end{array}$ \\
\hline $\begin{array}{l}\text { Torrelavega } \\
\text { (La Montaña) }\end{array}$ & $17-4-36$ & $\begin{array}{l}\text { Incendio de la iglesia con graves } \\
\text { daños. }\end{array}$ & Desconocido & $\begin{array}{l}\text { Nunz. C. 925, F. } 1 \\
\text { P-S Madrid L. } \\
152\end{array}$ \\
\hline $\begin{array}{l}\text { Torrelavega } \\
\text { (Tanos) }\end{array}$ & $5-4-36$ & $\begin{array}{l}\text { Incendio de la iglesia con graves } \\
\text { daños. }\end{array}$ & Desconocido & \begin{tabular}{|l|} 
P-S Madrid L. 152 \\
DSC, $7-\mathrm{V}-1936$ \\
\end{tabular} \\
\hline \multicolumn{5}{|c|}{$\begin{array}{r}\text { SEGOVIA } \\
\end{array}$} \\
\hline Segovia & $3-36$ & $\begin{array}{l}\text { Conato de incendio en un } \\
\text { convento. }\end{array}$ & Desconocido & Nunz. C. 945 , F. 3 \\
\hline
\end{tabular}




\begin{tabular}{|c|c|c|c|c|}
\hline $\begin{array}{l}\text { Provincia y } \\
\text { Localidad }\end{array}$ & Fecha & Tipo de Violencia & Autoría & Fuente \\
\hline \multicolumn{5}{|c|}{ SEVILLA } \\
\hline Sevilla & $1-5-36$ & Conato de asalto de una iglesia. & Desconocido & DSC, 7-V-1936 \\
\hline Sevilla & $3-5-36$ & Asalto y ocupación de una iglesia. & Comunistas & \begin{tabular}{|l|} 
Nunz. C. 925, F. 1 \\
$D S C, 7-\mathrm{V}-1936$ \\
\end{tabular} \\
\hline Almensilla & $5-36$ & Asalto y ocupación de una iglesia. & $\begin{array}{l}\text { Juventud } \\
\text { Socialista }\end{array}$ & Nunz. C. 925, F. 1 \\
\hline \begin{tabular}{|l|}
$\begin{array}{l}\text { Badolatosa } \\
\text { (Corcoya) }\end{array}$ \\
\end{tabular} & $4-36$ & $\begin{array}{l}\text { Asalto y saqueo de una iglesia. } \\
\text { Quema de objetos sagrados. }\end{array}$ & Desconocido & Nunz. C. 945 , F. 3 \\
\hline $\begin{array}{l}\text { Bollullos de } \\
\text { la Mitación }\end{array}$ & $29-2-36$ & $\begin{array}{l}\text { Asalto y saqueo de una iglesia. } \\
\text { Destrucción de una imagen. }\end{array}$ & Desconocido & $\begin{array}{l}\text { P-S Madrid L. } 152 \\
\text { Nunz. C. } 912 \\
\text { DSC, } 15-I V-1936 \\
\end{array}$ \\
\hline $\begin{array}{l}\text { Bollullos de } \\
\text { la Mitación }\end{array}$ & $27-4-36$ & Conato de asalto a la iglesia. & Comunistas & \begin{tabular}{|l|}
$D S C$, 7-V-1936 \\
$A B C, 29-\mathrm{IV}-1936$ \\
\end{tabular} \\
\hline Brenes & $1-5-36$ & $\begin{array}{l}\text { Asalto y saqueo de una iglesia. } \\
\text { Quema de imágenes y objetos de } \\
\text { culto. }\end{array}$ & Socialistas & $\begin{array}{l}\text { Nunz. C. } 925, \text { F. } 1 \\
D S C, 7-\mathrm{V}-1936\end{array}$ \\
\hline Camas & $18-3-36$ & Derribo de una cruz monumental. & Desconocido & \begin{tabular}{|l|}
$A B C$ y \\
Vanguardia, \\
19-III-36 \\
\end{tabular} \\
\hline Cantillana & $6-4-36$ & $\begin{array}{l}\text { Asalto y saqueo de una ermita. } \\
\text { Destrozo de imágenes. Se } \\
\text { traslada la campana a un centro } \\
\text { comunista. Tiene lugar junto al } \\
\text { asalto de un casino. }\end{array}$ & Socialistas & $\begin{array}{l}\text { P-S Madrid L. } \\
152 \\
\text { Nunz. C. } 925, \text { F. } 1 \\
\text { DSC, } 7-\mathrm{V}-1936\end{array}$ \\
\hline Coria del Río & $4-36$ & $\begin{array}{l}\text { Asalto y saqueo de una ermita. } \\
\text { Destrozo del mobiliario. }\end{array}$ & Desconocido & Nunz. C. 925, F. 1 \\
\hline Écija & $8-3-36$ & \begin{tabular}{|l} 
Conato de incendio en un \\
convento. Apedreamiento de \\
"algunas" iglesias (como mínimo \\
dos). Tiene lugar junto al asalto \\
del casino ecijano, de varios \\
comercios y de la sede de AP. Dos \\
automóviles incendiados. \\
\end{tabular} & Desconocido & $\begin{array}{l}\text { P-S Madrid L. } \\
152 \\
\text { Nunz. C. } 945 \\
\text { DSC, } 15-I V-1936\end{array}$ \\
\hline El Saucejo & $20-2-36$ & Incendio parcial de una iglesia. & Desconocido & $\begin{array}{l}\text { Nunz. C. } 945, \text { F. } 3 \\
\text { P-S Madrid L. } 152 \\
D S C, 15-I V-1936 \\
\end{array}$ \\
\hline $\begin{array}{l}\text { El Viso del } \\
\text { Alcor } \\
\end{array}$ & $1-5-36$ & Asalto y ocupación de la iglesia. & Socialistas & DSC, 7-V-1936 \\
\hline $\begin{array}{l}\text { Fuentes de } \\
\text { Andalucía }\end{array}$ & $20-2-36$ & Conato de incendio en una iglesia. & Desconocido & $\begin{array}{l}\text { P-S Madrid L. } 152 \\
\text { Nunz. C. } 912 \\
\text { DSC, 15-IV-1936 }\end{array}$ \\
\hline
\end{tabular}




\begin{tabular}{|c|c|c|c|c|}
\hline $\begin{array}{l}\text { Provincia y } \\
\text { Localidad }\end{array}$ & Fecha & Tipo de Violencia & Autoría & Fuente \\
\hline Guillena & $9-5-36$ & $\begin{array}{l}\text { Asalto y saqueo de la iglesia. } \\
\text { Destrozos en el mobiliario. Robo } \\
\text { de los objetos de culto. Tiene } \\
\text { lugar junto con el asalto de un bar } \\
\text { y una tienda. }\end{array}$ & Desconocido & $\begin{array}{l}\text { Nunz. C. } 925, \text { F. } 1 \\
A B C, 10-\mathrm{V}-1936\end{array}$ \\
\hline Herrera & $18-2-36$ & $\begin{array}{l}\text { Incendio parcial de la iglesia. } \\
\text { Tiene lugar junto al incendio del } \\
\text { archivo municipal. }\end{array}$ & Desconocido & $\begin{array}{l}\text { Nunz. C. 945, F. } 3 \\
\text { P-S Madrid L. } \\
152 \\
\end{array}$ \\
\hline Lebrija & $23-4-36$ & $\begin{array}{l}\text { Conato de incendio en una iglesia, } \\
\text { dos conventos y dos ermitas. Tiene } \\
\text { lugar junto con el asalto y saqueo } \\
\text { de dos domicilios, una tienda y la } \\
\text { sede de AP. }\end{array}$ & Desconocido & $\begin{array}{l}\text { Nunz. C. } 925, \text { F. } 1 \\
A B C, 25-I V-1936\end{array}$ \\
\hline Lora del Río & $5-36$ & $\begin{array}{l}\text { Derribo de una iglesia so pretexto } \\
\text { de su mal estado. }\end{array}$ & Desconocido & Nunz. C. 925 , F. 1 \\
\hline Los Corrales & $13-4-36$ & Derribo de una cruz monumental. & Desconocido & $\begin{array}{l}\text { Nunz. C. } 925, \text { F. } 1 \\
\text { P-S Madrid L. } 152 \\
\text { DSC, 7-V-1936 }\end{array}$ \\
\hline Marchena & $1-5-36$ & Asalto y ocupación de la iglesia. & Socialistas & \begin{tabular}{|l|} 
DSC, $7-\mathrm{V}-1936$ \\
La Vanguardia, \\
3-V-1936 \\
\end{tabular} \\
\hline Palomares & $20-2-36$ & \begin{tabular}{|l|} 
Conato de asalto a una iglesia. \\
Tiene lugar junto al asalto a la \\
sede de AP y quema de mobiliario. \\
\end{tabular} & Desconocido & $\begin{array}{l}\text { Nunz. C. } 912 \\
D S C, 15-I V-1936\end{array}$ \\
\hline Peñaflor & $20-2-36$ & $\begin{array}{l}\text { Asalto, saqueo y ocupación de } \\
\text { la iglesia. Quema de imágenes. } \\
\text { Tiene lugar junto al asalto de una } \\
\text { fábrica. }\end{array}$ & Desconocido & $\begin{array}{l}\text { Nunz. C. } 945, \text { F. } 3 \\
\text { P-S Madrid } \\
\text { L.1536 y } 152 \\
\text { DSC, } 15-I V-1936 \\
\end{array}$ \\
\hline $\begin{array}{l}\text { Puebla del } \\
\text { Río }\end{array}$ & $3-5-36$ & Asalto y saqueo de una iglesia. & Desconocido & $D S C, 7-\mathrm{V}-1936$ \\
\hline $\begin{array}{l}\text { Real de la } \\
\text { Jara }\end{array}$ & $13-4-36$ & Destrozo de una cruz monumental. & Desconocido & \begin{tabular}{|l} 
P-S Madrid L. 152 \\
DSC, 7-V-1936 \\
\end{tabular} \\
\hline $\begin{array}{l}\text { San Juan de } \\
\text { Aznalfarache }\end{array}$ & $13-4-36$ & $\begin{array}{l}\text { Destrozo y quema de una cruz } \\
\text { monumental. }\end{array}$ & Desconocido & $\begin{array}{l}\text { P-S Madrid L. } 152 \\
\text { DSC, 7-V-1936 }\end{array}$ \\
\hline $\begin{array}{l}\text { San Juan de } \\
\text { Aznalfarache }\end{array}$ & $24-4-36$ & Asalto y ocupación de una ermita. & Socialistas & $\begin{array}{l}\text { Nunz. C. } 925, \text { F. } 1 \\
A B C, 25-I V-1936 \\
\end{array}$ \\
\hline Tocina & $29-3-36$ & Incendio parcial de una ermita. & Desconocido & $\begin{array}{l}\text { Nunz. C. } 925, \text { F. } 1 \\
\text { P-S Madrid L. } 152\end{array}$ \\
\hline Tomares & $10-4-36$ & Derribo de una cruz monumental. & Desconocido & P-S Madrid L. 152 \\
\hline $\begin{array}{l}\text { Valencina de } \\
\text { la Concepción }\end{array}$ & $10-3-36$ & $\begin{array}{l}\text { Asalto del local donde se guardaban } \\
\text { los pasos de Semana Santa y } \\
\text { destrucción parcial de éstos. }\end{array}$ & Comunistas & \begin{tabular}{|l} 
P-S Madrid L. \\
152 \\
$D S C, 15-\mathrm{IV}-1936$ \\
\end{tabular} \\
\hline
\end{tabular}




\begin{tabular}{|c|c|c|c|c|}
\hline $\begin{array}{l}\text { Provincia y } \\
\text { Localidad }\end{array}$ & Fecha & Tipo de Violencia & Autoría & Fuente \\
\hline \multicolumn{5}{|c|}{ SORIA } \\
\hline Portelárbol & $26-4-36$ & $\begin{array}{l}\text { Incendio parcial de una ermita. } \\
\text { Quema de imágenes. }\end{array}$ & Desconocido & \begin{tabular}{|l} 
Nunz. C. 925, F. 1 \\
P-S Madrid L. \\
2377 \\
\end{tabular} \\
\hline \multicolumn{5}{|c|}{ TARRAGONA } \\
\hline Tarragona & $22-2-36$ & Incendio parcial de una iglesia. & Desconocido & $A B C, 24-$ II-1936 \\
\hline Montblanch & $16-3-36$ & Derribo de una cruz monumental. & Desconocido & P-S Madrid L. 152 \\
\hline \multicolumn{5}{|c|}{\begin{tabular}{|l} 
TERUEL \\
\end{tabular}} \\
\hline $\begin{array}{l}\text { Belmonte de } \\
\text { San José }\end{array}$ & $16-6-36$ & Asalto a una ermita. & Desconocido & $\begin{array}{l}\text { La Vanguardia, } \\
18-\text { VI-1936 }\end{array}$ \\
\hline Calaceite & $30-3-36$ & $\begin{array}{l}\text { Destrucción de "todas" las cruces } \\
\text { monumentales del municipio (al } \\
\text { menos tres). }\end{array}$ & Desconocido & $\begin{array}{l}\text { P-S Madrid L. } \\
152 \\
A B C, 3-I V-36 \\
\end{array}$ \\
\hline Escucha & $14-4-36$ & $\begin{array}{l}\text { Incendio de la iglesia con graves } \\
\text { daños. }\end{array}$ & Desconocido & \begin{tabular}{|l|} 
P-S Madrid L. 152 \\
DSC, 7-V-1936 \\
\end{tabular} \\
\hline $\begin{array}{l}\text { Fuentes } \\
\text { Claras }\end{array}$ & $5-36$ & Asalto y saqueo de una iglesia. & Desconocido & Nunz. C. 925 , F. 1 \\
\hline \multicolumn{5}{|c|}{ TOLEDO } \\
\hline Toledo & $3-36$ & $\begin{array}{l}\text { Asalto de un establecimiento de } \\
\text { catequesis. }\end{array}$ & Desconocido & Nunz. C. 945 , F. 3 \\
\hline Barcience & $5-4-36$ & $\begin{array}{l}\text { Apedreamiento de la iglesia. } \\
\text { Destrozos en el edificio. }\end{array}$ & Desconocido & $\begin{array}{l}\text { P-S Madrid L. } \\
4550 \\
\end{array}$ \\
\hline $\begin{array}{l}\text { Burguillos de } \\
\text { Toledo }\end{array}$ & $17-5-36$ & $\begin{array}{l}\text { Asalto y ocupación de la casa } \\
\text { rectoral. }\end{array}$ & Socialistas & $\begin{array}{l}\text { Nunz. C. } 925, \text { F. } 1 \\
\text { P-S Madrid 2416 } \\
\text { DSC, } 8 \text {-VII-36 } \\
\end{array}$ \\
\hline $\begin{array}{l}\text { Carpio de } \\
\text { Tajo }\end{array}$ & $17-5-36$ & $\begin{array}{l}\text { Incendio de una ermita con graves } \\
\text { daños. El cura fue tiroteado. }\end{array}$ & Desconocido & $\begin{array}{l}\text { Nunz. C. 925, F. } 1 \\
\text { P-S Madrid L. } \\
4550 \\
\end{array}$ \\
\hline Escalona & $30-4-36$ & Derribo de una cruz monumental. & Desconocido & $\begin{array}{l}\text { P-S Madrid L. } \\
2377\end{array}$ \\
\hline Esquivias & $5-36$ & $\begin{array}{l}\text { Incendio de una ermita con graves } \\
\text { daños. Asalto de la iglesia. Robo } \\
\text { de los badajos de las campanas. }\end{array}$ & Desconocido & $\begin{array}{l}\text { Nunz. C. } 925, \text { F. } 1 \\
\text { P-S Madrid L. } \\
4550\end{array}$ \\
\hline Navahermosa & $8-5-36$ & $\begin{array}{l}\text { Asalto y ocupación de la casa } \\
\text { rectoral. }\end{array}$ & Socialistas & Nunz. C. 925 , F. 1 \\
\hline Nombela & $20-4-36$ & $\begin{array}{l}\text { Asalto y ocupación de la casa } \\
\text { rectoral. }\end{array}$ & $\begin{array}{l}\text { Juventud } \\
\text { Socialista }\end{array}$ & $\begin{array}{l}\text { Nunz. C. } 925, \text { F. } 1 \\
\text { DSC, 8-VII-36 } \\
\text { ADT, Secretaría } \\
\end{array}$ \\
\hline Quismondo & $4-36$ & $\begin{array}{l}\text { Asalto de la casa rectoral. } \\
\text { Destrozo del mobiliario. }\end{array}$ & Desconocido & \begin{tabular}{|l} 
Nunz. C. 925, F. 1 \\
$D S C, 8$-VII-36
\end{tabular} \\
\hline
\end{tabular}




\begin{tabular}{|c|c|c|c|c|}
\hline $\begin{array}{l}\text { Provincia y } \\
\text { Localidad }\end{array}$ & Fecha & Tipo de Violencia & Autoría & Fuente \\
\hline $\begin{array}{l}\text { Talavera de la } \\
\text { Reina }\end{array}$ & $13-3-36$ & $\begin{array}{l}\text { Apedreamiento y conato de asalto } \\
\text { del centro de Acción Católica. }\end{array}$ & Desconocido & $\begin{array}{l}\text { Nunz. C. } 945 \text { y } \\
912\end{array}$ \\
\hline Urda & $4-36$ & Asalto y ocupación de una ermita. & $\begin{array}{l}\text { Juve } \\
\text { Soci }\end{array}$ & Nunz. C. 925 , F. 1 \\
\hline $\begin{array}{l}\text { Val de Santo } \\
\text { Domingo }\end{array}$ & $10-5-36$ & $\begin{array}{l}\text { Estalla una bomba durante la } \\
\text { celebración de misa. Un grupo } \\
\text { golpea a un sacerdote y le } \\
\text { amenaza con una pistola. }\end{array}$ & Socialistas & $\begin{array}{l}\text { DSC, 8-VII-36 } \\
\text { ADT, Secretaría }\end{array}$ \\
\hline Valdeverdeja & $3-36$ & Apedreamiento de la casa rectoral. & Desconocido & $\begin{array}{l}\text { Nunz. C. } 945, \text { F. } 3 \\
\text { ADT, Secretaría }\end{array}$ \\
\hline Villacañas & $4-36$ & $\begin{array}{l}\text { Asalto y ocupación de tres } \\
\text { ermitas. }\end{array}$ & Desconocido & Nunz. C. 925, F. 1 \\
\hline \multicolumn{5}{|c|}{ VALENCIA } \\
\hline Valencia & $\left|\begin{array}{c}20 y \\
21-2-36\end{array}\right|$ & $\begin{array}{l}\text { Incendio de dos capillas con } \\
\text { graves daños. Destrozo de } \\
\text { imágenes. Conato de incendio en } \\
\text { otra iglesia. } \\
\end{array}$ & Desconocido & $\begin{array}{l}\text { P-S Madrid } \\
\text { L.1536 }\end{array}$ \\
\hline $\begin{array}{l}\text { Valencia } \\
\text { (Cañamelar) }\end{array}$ & $20-2-36$ & $\begin{array}{l}\text { Asalto y saqueo de la ermita. } \\
\text { Destrozo de las imágenes. }\end{array}$ & Desconocido & \begin{tabular}{|l} 
Nunz. C. 945, F. 3 \\
P-S Madrid L. 152 \\
\end{tabular} \\
\hline Alberique & $18-2-36$ & Incendio parcial de una iglesia. & Desconocido & $\begin{array}{l}\text { P-S Madrid } \\
\text { L.1536 }\end{array}$ \\
\hline Alboraya & $30-5-36$ & $\begin{array}{l}\text { Incendio de una iglesia con graves } \\
\text { daños. }\end{array}$ & Desconocido & Nunz. C. 925 , F. 1 \\
\hline Alcácer & $17-2-36$ & Conato de incendio en una iglesia. & Desconocido & Nunz. C. 967, F. 1 \\
\hline Alcira & $20-2-36$ & $\begin{array}{l}\text { Conato de incendio en "varias" } \\
\text { iglesias (al menos dos). }\end{array}$ & Desconocido & $\begin{array}{l}\text { Nunz. C. } 945, \text { F. } 3 \\
\text { P-S Madrid } \\
\text { L.1536 y } 152 \\
\end{array}$ \\
\hline $\begin{array}{l}\text { Alcira } \\
\text { (Alquerieta de } \\
\text { Alcira) }\end{array}$ & $20-2-36$ & $\begin{array}{l}\text { Incendio de la iglesia con graves } \\
\text { daños. }\end{array}$ & Desconocido & $\begin{array}{l}\text { Nunz. C. } 945 \text {, F. } 3 \\
\text { P-S Madrid L. } 152\end{array}$ \\
\hline Alcira & $4-5-36$ & Destrozo de una cruz monumental. & Desconocido & $\begin{array}{l}\text { La Vanguardia, } \\
\text { 6-V-1936 }\end{array}$ \\
\hline Alcira & $\mid \begin{array}{c}12 \mathrm{y} \\
13-5-36\end{array}$ & $\begin{array}{l}\text { Incendio de dos iglesias y un } \\
\text { convento con graves daños. } \\
\text { Asalto de un colegio. Se hace } \\
\text { junto a una sede tradicionalista y } \\
\text { un domicilio particular. } \\
\end{array}$ & $\begin{array}{l}\text { Socialistas y } \\
\text { comunistas }\end{array}$ & $\begin{array}{l}\text { Nunz. C. 925, F. } 1 \\
\text { P-S Madrid L. } \\
2376\end{array}$ \\
\hline Alfarrasí & $16-6-36$ & Destrozo de una cruz monumental. & Desconocido & \begin{tabular}{|l|} 
La Vanguardia, \\
$18-\mathrm{VI}-1936$ \\
\end{tabular} \\
\hline $\begin{array}{l}\text { Algimia de } \\
\text { Alfara }\end{array}$ & $15-5-36$ & $\begin{array}{l}\text { Incendio de la iglesia con graves } \\
\text { daños. }\end{array}$ & Desconocido & Nunz. C. 925, F. 1 \\
\hline
\end{tabular}




\begin{tabular}{|c|c|c|c|c|}
\hline $\begin{array}{l}\text { Provincia y } \\
\text { Localidad }\end{array}$ & Fecha & Tipo de Violencia & Autoría & Fuente \\
\hline Alginet & $7-3-36$ & $\begin{array}{l}\text { Asalto y saqueo de la iglesia. } \\
\text { Destrozo de imágenes y objetos } \\
\text { de culto. }\end{array}$ & Desconocido & $\begin{array}{l}\text { Nunz. C. } 967, \text { F. } 1 \\
\text { P-S Madrid L. } \\
152\end{array}$ \\
\hline Almusafes & $20-2-36$ & $\begin{array}{l}\text { Incendio parcial de la iglesia. } \\
\text { Quema de mobiliario e imágenes. }\end{array}$ & Desconocido & $\begin{array}{l}\text { Nunz. C. } 945, \text { F. } 3 \\
\text { P-S Madrid L. } \\
152 \text { y L. } 1536 .\end{array}$ \\
\hline Barcheta & $16-5-36$ & $\begin{array}{l}\text { Incen } \\
\text { daño }\end{array}$ & Desconocido & Nunz. C. 925, F. 1 \\
\hline $\begin{array}{l}\text { Barraca de } \\
\text { Aguas Vivas }\end{array}$ & $30-3-36$ & $\begin{array}{l}\text { Asalto y saqueo de la iglesia. } \\
\text { Destrozo de imágenes. }\end{array}$ & Desconocido & $\begin{array}{l}\text { Nunz. C. } 945 \text {, F. } 3 \\
\text { P-S Madrid } \\
\text { L.1536 } \\
\end{array}$ \\
\hline & $26-3-36$ & Conato de incendio en la iglesia. & Desconocido & \begin{tabular}{|l|} 
Nunz. C. 967, F. 1 \\
P-S Madrid L. 152 \\
\end{tabular} \\
\hline Beniganim & $23-2-36$ & $\begin{array}{l}\text { eo de la iglesia y } \\
\text { to. Destrozo de } \\
\text { ojetos de culto. }\end{array}$ & Desconocido & $\begin{array}{l}\text { Nunz. C. 925, F. } 1 \\
\text { P-S Madrid } \\
\text { L.1536 } \\
\end{array}$ \\
\hline Benirredra & $13-4-36$ & $\begin{array}{l}\text { Conato de asalto de un convento y } \\
\text { una iglesia. }\end{array}$ & $\begin{array}{c}\text { Militantes de } \\
\text { una sociedad } \\
\text { obrera } \\
\end{array}$ & Nunz. C. 925 , F. 1 \\
\hline Canals & -36 & nato d & Desconocido & Nunz. C. 945, F. 3 \\
\hline Carca & $13-5-36$ & $\begin{array}{l}\text { Incendio de la iglesia y de otros } \\
\text { dos "edificios religiosos" con } \\
\text { graves daños. }\end{array}$ & $\begin{array}{l}\text { Socialistas y } \\
\text { comunistas }\end{array}$ & $\begin{array}{l}\text { Nunz. C. 925, F. } 1 \\
\text { P-S Madrid L. } \\
2376 \\
\end{array}$ \\
\hline Cárcer & $4-3-36$ & $\begin{array}{l}\text { Asalto y saqueo de una ermita. } \\
\text { Destrozo de una imagen. }\end{array}$ & Desconocido & \begin{tabular}{|l|} 
P-S Madrid L. 152 \\
Nunz. C. 945 y \\
912 \\
DSC, $15-I V-1936$ \\
\end{tabular} \\
\hline Carlet & -36 & Conato $\mathrm{de}$ & do & Nunz. C. 925, F. 1 \\
\hline Casas de Utiel & $4-36$ & $\begin{array}{l}\text { Incendio de la iglesia con graves } \\
\text { daños. }\end{array}$ & Desconocido & Nunz. C. 925, F. 1 \\
\hline Catarroja & $1-5-36$ & $\begin{array}{l}\text { Asalto y saqueo de una iglesia } \\
\text { y una casa rectoral. Quema de } \\
\text { imágenes y objetos de culto. }\end{array}$ & Desconocido & \begin{tabular}{|l|} 
Nunz. C. 925, F. 1 \\
P-S Madrid L. \\
2376 \\
DSC, 7-V-1936 \\
\end{tabular} \\
\hline Chera & $30-3-36$ & $\begin{array}{l}\text { Incendio de una iglesia con graves } \\
\text { daños. Quema de imágenes y } \\
\text { objetos de culto. }\end{array}$ & Desconocido & $\begin{array}{l}\text { Nunz. C. } 945, \text { F. } 3 \\
\text { P-S Madrid } \\
\text { L.1536 y } 152 \\
\end{array}$ \\
\hline Cheste & $3-4-36$ & $\begin{array}{l}\text { Asalto, saqueo de la casa rectoral. } \\
\text { Destrozo del mobiliario. }\end{array}$ & Desconocido & Nunz. C. 925, F. 1 \\
\hline \begin{tabular}{|l|} 
Cuart de \\
Poblet
\end{tabular} & $1-5-36$ & $\begin{array}{l}\text { Destrucción de una cruz } \\
\text { monumental. }\end{array}$ & Desconocido & Nunz. C. 925 , F. 1 \\
\hline
\end{tabular}




\begin{tabular}{|c|c|c|c|c|}
\hline $\begin{array}{c}\text { Provincia y } \\
\text { Localidad }\end{array}$ & Fecha & Tipo de Violencia & Autoría & Fuente \\
\hline Cullera & $31-3-36$ & Incendio parcial de una iglesia. & Desconocido & $\begin{array}{l}\text { P-S Madrid } \\
\text { L.1536 }\end{array}$ \\
\hline Cullera & $1-5-36$ & $\begin{array}{l}\text { Asalto y saqueo de una iglesia. } \\
\text { Quema de imágenes. }\end{array}$ & Desconocido & $\begin{array}{l}\text { Nunz. C. 925, F. } 1 \\
\text { P-S Madrid L. } \\
2377 \\
\text { DSC, 7-V-1936 } \\
\end{array}$ \\
\hline Cullera & $13-5-36$ & $\begin{array}{l}\text { Incendio de una iglesia con graves } \\
\text { daños. }\end{array}$ & Desconocido & Nunz. C. 925 , F. 1 \\
\hline $\begin{array}{l}\text { Fuente la } \\
\text { Higuera }\end{array}$ & $12-4-36$ & $\begin{array}{l}\text { Incendio de una iglesia y una } \\
\text { ermita con graves daños. Quema } \\
\text { de imágenes y objetos de culto. }\end{array}$ & Socialistas & $\begin{array}{l}\text { Nunz. C. 925, F. } 1 \\
\text { P-S Madrid L. } \\
152 \\
\end{array}$ \\
\hline $\begin{array}{l}\text { Fuenterro- } \\
\text { bles }\end{array}$ & $4-36$ & $\begin{array}{l}\text { Asalto y saqueo de una ermita. } \\
\text { Destrozo del mobiliario. }\end{array}$ & Desconocido & Nunz. C. 945 , F. 3 \\
\hline $\begin{array}{l}\text { Gandía } \\
\text { (Beniopa) }\end{array}$ & $10-4-36$ & $\begin{array}{l}\text { Asalto y ocupación de la casa } \\
\text { rectoral y de la iglesia. Quema de } \\
\text { imágenes y objetos de culto. }\end{array}$ & Socialistas & $\begin{array}{l}\text { P-S Madrid L. } \\
152 \\
D S C, 7-\mathrm{V}-1936 \\
\end{array}$ \\
\hline $\begin{array}{l}\text { Gandía } \\
\text { de Gan }\end{array}$ & $1-5-36$ & Asalto y ocupación de una iglesia. & Desconocido & $\begin{array}{l}D S C, 7-\mathrm{V}-1936 \\
A B C, 2-\mathrm{V}-1936 \\
\end{array}$ \\
\hline Jaraco & $14-4-36$ & \begin{tabular}{|l|} 
Asalto y saqueo de la iglesia. \\
Destrucción de objetos de culto.
\end{tabular} & Desconocido & $\begin{array}{l}\text { Nunz. C. } 925, \text { F. } 1 \\
D S C, 7-V-1936 \\
\end{array}$ \\
\hline Jeresa & $26-3-36$ & $\begin{array}{l}\text { Asalto y ocupación de la casa } \\
\text { rectoral. }\end{array}$ & Desconocido & Nunz. C. 925 , F. 1 \\
\hline Llaurí & $16-5-36$ & $\begin{array}{l}\text { Incendio de la iglesia con graves } \\
\text { daños. }\end{array}$ & Desconocido & Nunz. C. 925, F. 1 \\
\hline $\begin{array}{l}\text { Lugar Nuevo } \\
\text { de Fenollet }\end{array}$ & $-4-36$ & Incendio parcial de la iglesia. & Desconocido & Nunz. C. 925 , F. 1 \\
\hline Masalavés & $1-5-36$ & $\begin{array}{l}\text { Asalto y saqueo de una iglesia. } \\
\text { Quema de imágenes. }\end{array}$ & Desconocido & $\begin{array}{l}\text { P-S Madrid L. } \\
2377\end{array}$ \\
\hline Museros & $20-2-36$ & $\begin{array}{l}\text { Asalto y saqueo de la iglesia y de la } \\
\text { casa rectoral. Quema de mobiliario, } \\
\text { imágenes y objetos de culto. }\end{array}$ & Desconocido & $\begin{array}{l}\text { Nunz. C. } 945, \text { F. } 3 \\
\text { P-S Madrid L. } \\
152 \text { y L. } 1536 . \\
\end{array}$ \\
\hline Onteniente & $\begin{array}{c}19 y \\
20-2-36\end{array}$ & $\begin{array}{l}\text { Destrozos en lápidas, cruces e } \\
\text { imágenes de las calles. Asalto y } \\
\text { saqueo de la iglesia. Destrozo de } \\
\text { imágenes y objetos de culto. }\end{array}$ & Desconocido & $\begin{array}{l}\text { P-S Madrid } \\
\text { L.1536 }\end{array}$ \\
\hline $\begin{array}{l}\text { Poliñá del } \\
\text { Júcar }\end{array}$ & $1-5-36$ & $\begin{array}{l}\text { Asalto y saqueo de la iglesia. } \\
\text { Quema de algunos objetos de } \\
\text { culto. Otros son robados. }\end{array}$ & Desconocido & $\begin{array}{l}\text { Nunz. C. 925, F. } 1 \\
\text { P-S Madrid L. } \\
2377 \\
\end{array}$ \\
\hline Puebla Larga & $15-5-36$ & Conato de incendio en una iglesia. & Desconocido & Nunz. C. 925, F. 1 \\
\hline Puig & $20-2-36$ & $\begin{array}{l}\text { Asalto y saqueo de la casa } \\
\text { rectoral y de la iglesia. Quema del } \\
\text { mobiliario. Robo y destrozo de } \\
\text { imágenes. }\end{array}$ & Desconocido & $\begin{array}{l}\text { Nunz. C. } 945 \\
\text { P-S Madrid } \\
\text { L.1536 y } 152 \\
D S C, 15 \text {-IV-1936 }\end{array}$ \\
\hline
\end{tabular}




\begin{tabular}{|c|c|c|c|c|}
\hline $\begin{array}{l}\text { Provincia y } \\
\text { Localidad }\end{array}$ & Fecha & Tipo de Violencia & Autoría & Fuente \\
\hline Puig & $5-3-36$ & $\begin{array}{l}\text { Asalto y saqueo de la iglesia. } \\
\text { Destrozo de imágenes. }\end{array}$ & Desconocido & \begin{tabular}{|l|} 
P-S Madrid L. 152 \\
DSC, $15-I V-1936$ \\
\end{tabular} \\
\hline Rafelguaraf & $15-5-36$ & $\begin{array}{l}\text { Incendio de la iglesia con graves } \\
\text { daños. }\end{array}$ & Desconocido & Nunz. C. 925 , F. 1 \\
\hline Requena & $23-3-36$ & $\begin{array}{l}\text { Asalto y saqueo de tres conventos. } \\
\text { Quema del mobiliario y objetos de } \\
\text { culto de uno de ellos. }\end{array}$ & Desconocido & $\begin{array}{l}\text { Nunz. C. } 945, \text { F. } 3 \\
\text { P-S Madrid } \\
\text { L.1536 } \\
\end{array}$ \\
\hline Sagunto & $16-4-36$ & $\begin{array}{l}\text { Estallan dos bombas en una iglesia } \\
\text { causando fuertes desperfectos. }\end{array}$ & Desconocido & \begin{tabular}{|l|} 
P-S Madrid L. 152 \\
P-S Madrid L. \\
2377 \\
DSC, 7-V-1936 \\
\end{tabular} \\
\hline Silla & $15-3-36$ & $\begin{array}{l}\text { Asalto y saqueo de una iglesia. } \\
\text { Quema de imágenes. }\end{array}$ & Desconocido & $\begin{array}{l}\text { Nunz. C. } 945, \text { F. } 3 \\
\text { P-S Madrid L. } 152 \\
\text { DSC, 15-IV-1936 } \\
\end{array}$ \\
\hline $\begin{array}{l}\text { Simat de } \\
\text { Valldigna }\end{array}$ & $26-3-36$ & $\begin{array}{l}\text { Asalto y saqueo de la iglesia. } \\
\text { Destrozo de imágenes y objetos } \\
\text { de culto. }\end{array}$ & Desconocido & $\begin{array}{l}\text { Nunz. C. } 945, \text { F. } 3 \\
\text { P-S Madrid } \\
\text { L.1536 y } 152 \\
\end{array}$ \\
\hline $\begin{array}{l}\text { Simat de } \\
\text { Valldigna }\end{array}$ & $10-4-36$ & $\begin{array}{l}\text { Incendio parcial de una ermita. } \\
\text { Quema de imágenes y objetos de } \\
\text { culto. }\end{array}$ & Desconocido & $\begin{array}{l}\text { Nunz. C. 925, F. } 1 \\
\text { P-S Madrid L. } \\
152 \\
\end{array}$ \\
\hline $\begin{array}{l}\text { Tabernes de } \\
\text { Valldigna }\end{array}$ & $\begin{array}{c}25 y \\
26-3-36\end{array}$ & \begin{tabular}{|l|} 
Incendio de una iglesia con graves \\
daños. Asalto y saqueo de otra \\
iglesia y dos ermitas más. Quema de \\
imágenes y mobiliario. Tiene lugar \\
junto al asalto de la sede de la DRV. \\
\end{tabular} & Desconocido & $\begin{array}{l}\text { Nunz. C. } 945, \text { F. } 3 \\
\text { P-S Madrid } \\
\text { L.1536 y } 152 \\
\text { DSC, } 15-I V-1936\end{array}$ \\
\hline $\begin{array}{l}\text { Tabernes de } \\
\text { Valldigna }\end{array}$ & $30-3-36$ & $\begin{array}{l}\text { Asalto y saqueo de una iglesia. } \\
\text { Robo de objetos de culto. }\end{array}$ & Desconocido & $\begin{array}{l}\text { P-S Madrid L. } 152 \\
\text { La Vanguardia, } \\
\text { 1-IV-1936 }\end{array}$ \\
\hline $\begin{array}{l}\text { Utiel (Las } \\
\text { Cuevas) }\end{array}$ & $30-3-36$ & $\begin{array}{l}\text { Asalto y saqueo de la iglesia. } \\
\text { Quema de imágenes, mobiliario y } \\
\text { objetos de culto. }\end{array}$ & Desconocido & Nunz. C. 945 , F. 3 \\
\hline $\begin{array}{l}\text { Villanueva de } \\
\text { Castellón }\end{array}$ & $15-3-36$ & $\begin{array}{l}\text { Asalto y ocupación de un } \\
\text { convento que servía de asilo y } \\
\text { colegio. }\end{array}$ & Desconocido & $\begin{array}{l}\text { Nunz. C. } 925 \\
\text { P-S Madrid L. } 152 \\
\text { DSC, 15-IV-1936 } \\
\end{array}$ \\
\hline Zarra & $14-3-36$ & Asalto y ocupación de la iglesia. & cido & Nunz. C. 967, F. 1 \\
\hline \multicolumn{5}{|c|}{ VALLADOLID } \\
\hline Valladolid & $22-3-36$ & Incendio parcial de una iglesia. & Desconocido & $\begin{array}{l}\text { Nunz. C. } 945 \text {, F. } 3 \\
\text { P-S Madrid } \\
\text { L.1536 } \\
\end{array}$ \\
\hline Alcazarén & $5-36$ & Destrozo de cruces de un Calvario. & Desconocido & Nunz. C. 925 , F. 1 \\
\hline \multicolumn{5}{|c|}{ VIZCAYA } \\
\hline Sestao & $15-3-36$ & $\begin{array}{l}\text { Asalto y disparos dentro de una } \\
\text { iglesia. Daños en objetos de culto. }\end{array}$ & Desconocido & Nunz. C. 945 , F. 3 \\
\hline
\end{tabular}




\begin{tabular}{|c|c|c|c|c|}
\hline $\begin{array}{l}\text { Provincia y } \\
\text { Localidad }\end{array}$ & Fecha & Tipo de Violencia & Autoría & Fuente \\
\hline \multicolumn{5}{|c|}{ ZAMORA } \\
\hline Zamora & $3-36$ & $\begin{array}{l}\text { Derribo y destrozo de la estatua de } \\
\text { un religioso. }\end{array}$ & Desconocido & Nunz. C. 945 , F. 3 \\
\hline Zamora & $31-3-36$ & $\begin{array}{l}\text { Derribo de tres cruces } \\
\text { monumentales. }\end{array}$ & Desconocido & $\begin{array}{l}\text { P-S Madrid L. } \\
152\end{array}$ \\
\hline Zamora & $5-36$ & $\begin{array}{l}\text { Apaleamiento de un sacerdote } \\
\text { tras el entierro de un militante } \\
\text { comunista. Queda herido grave. }\end{array}$ & Desconocido & Nunz. C. 925, F. 1 \\
\hline Zamora & $5-36$ & $\begin{array}{l}\text { Explosión de cartuchos de } \\
\text { dinamita cerca de un convento. } \\
\text { Conato de asalto. }\end{array}$ & Desconocido & Nunz. C. 925, F. 1 \\
\hline Argañín & $5-36$ & Apedreamiento de la casa rectoral. & Desconocido & Nunz. C. 925, F. 1 \\
\hline Losacio & $5-36$ & $\begin{array}{l}\text { Asalto y saqueo de una iglesia. } \\
\text { Robo de una imagen. }\end{array}$ & Desconocido & Nunz. C. 925 , F. 1 \\
\hline Montamarta & $23-2-36$ & $\begin{array}{l}\text { Un cura herido levemente durante } \\
\text { un entierro. }\end{array}$ & Desconocido & \begin{tabular}{|l} 
Nunz. C. 925, F. 1 \\
Nunz. C. 912 \\
\end{tabular} \\
\hline Requejo & $15-6-36$ & Asalto y ocupación de una ermita. & Anarquistas & $\begin{array}{l}\text { La Vanguardia, } \\
17-V I-1936 \\
\end{array}$ \\
\hline Tolilla & $5-36$ & $\begin{array}{l}\text { na iglesia. Pintadas } \\
\text { en su interior. }\end{array}$ & Desconocido & Nunz. C. 925 , F. 1 \\
\hline \multicolumn{5}{|c|}{ ZARAGOZA } \\
\hline Zaragoza & $13-6-36$ & $\begin{array}{l}\text { Asalto y saqueo de una iglesia. } \\
\text { Destrozo de las imágenes. }\end{array}$ & Desconocido & \begin{tabular}{|l} 
La Vanguardia, \\
$14-\mathrm{VI}-1936$ \\
\end{tabular} \\
\hline Alpartir & $24-2-36$ & Apedreamiento de la casa rectoral. & Desconocido & Nunz. C. 945, F. 3 \\
\hline Azuara & $30-3-36$ & $\begin{array}{l}\text { Asalto y saqueo de una iglesia. } \\
\text { Robo de objetos de culto. Conato } \\
\text { de asalto a una ermita. }\end{array}$ & Desconocido & $\begin{array}{l}\text { P-S Madrid L. } \\
152\end{array}$ \\
\hline Caspe & $5-36$ & $\begin{array}{l}\text { Incendio de un convento con } \\
\text { graves daños. }\end{array}$ & Desconocido & Nunz. C. 925, F. 1 \\
\hline Mallén & $2-6-36$ & $\begin{array}{l}\text { Asalto y saqueo de una ermita. } \\
\text { Destrozos de imágenes. }\end{array}$ & Desconocido & \begin{tabular}{|l|} 
La Vanguardia, \\
3-VI-1936 \\
\end{tabular} \\
\hline Morés & $3-36$ & $\begin{array}{l}\text { Asalto de una iglesia para robar } \\
\text { las campanas. }\end{array}$ & Desconocido & Nunz. C. 945 , F. 3 \\
\hline Novillas & $18-3-36$ & Incendio parcial de la iglesia. & Desconocido & $\begin{array}{l}\text { Nunz. C. } 945, \text { F. } 3 \\
\text { P-S Madrid } \\
\text { L.1536 } \\
\end{array}$ \\
\hline $\begin{array}{l}\text { Pradilla de } \\
\text { Ebro }\end{array}$ & $3-36$ & $\begin{array}{l}\text { Se arrojan botellas de líquido } \\
\text { inflamable contra la sacristía. }\end{array}$ & Desconocido & Nunz. C. 945 , F. 3 \\
\hline $\begin{array}{l}\text { Torres de } \\
\text { Berrellén }\end{array}$ & $20-2-36$ & $\begin{array}{l}\text { Incendio de la iglesia con graves } \\
\text { daños. Quema de las imágenes y } \\
\text { robo del cepillo. }\end{array}$ & Desconocido & $\begin{array}{l}\text { Nunz. C. } 945, \text { F. } 3 \\
\text { P-S Madrid L. } 152 \\
\text { DSC, 15-IV-1936 } \\
\end{array}$ \\
\hline Used & $5-36$ & Asalto de una casa rectoral. & Desconocido & Nunz. C. 925, F. 1 \\
\hline
\end{tabular}




\section{BIBLIOGRAFÍA}

Álvarez Tardío, M. 2002. Anticlericalismo y libertad de conciencia. Política y religión en la Segunda República española (1931-1936), Madrid: CEPC.

Álvarez Tardío, M. 2009. «La revolución de las conciencias. Política y secularización en el primer bienio, 1931-1933», en F. Montero García y J. Cueva Merino (eds.), Laicismo y catolicismo. El conflicto político-religioso en la Segunda República. Universidad de Alcalá de Henares: 47-73.

Álvarez Tardío, M. y Villa García, R. 2010. El precio de la exclusión. La política durante la Segunda República, Madrid: 2010.

A. C. N. P. de Oviedo. 1935. Asturias roja. Sacerdotes y religiosos perseguidos y martirizados, Oviedo: A. C. N. de P. de Oviedo.

Andrés-Gallego, J. y Pazos, A. M. 1999. La Iglesia en la España contemporánea. Vol II: 1936-1999. Madrid: Encuentro.

Batllori, M. 1985. «En torno a las relaciones Iglesia-Estado en España durante un periodo conflictivo: febrero-julio de 1936», en C. Moya Espí, L. Rodríguez de Zúñiga y C. Iglesias. Homenaje a José Antonio Maravall, Madrid: CIS.

Blázquez Miguel, J. 2009. España turbulenta. Alteraciones, violencia y sangre durante la II República: 716-717.Villanueva del Pardillo (Madrid) Tomás Pérez y María Dolores.

Cárcel Ortí, V. 2000. La gran persecución. España, 1931-1939. Barcelona: Planeta.

Cárcel Ortí, V. 2008. Pío XI entre la República y Franco, Madrid: Biblioteca de Autores Cristianos.

Cibrián, R. 1978. «Violencia política y crisis democrática: España en 1936». Revista de Estudios Políticos 6: 84.

Conway, M. y Buchanan, T. 1996. Political Catholicism in Europe, 1918-1965. Oxford University Press, USA.

Dionisio, M.A. 2011. Isidro Gomá ante la dictadura y la República. Toledo: Instituto Teológico San Ildefonso.

García-Prous, C. 1996. Relaciones Iglesia-Estado en la Segunda República Española, Córdoba: Caja Sur.

Gil Andrés, C. 2000. Echarse a la calle. Amotinados, huelguistas y revolucionarios (La Rioja, 1890-1936). Zaragoza: Prensas Universitarias.

González Gullón, J. L. 2011. El clero en la Segunda República. Madrid, 193119363: 90-397 Burgos: Monte Carmelo.

Grandío Seoane, E. 1998. Los orígenes de la derecha gallega: la CEDA en Galicia (1931-1936): 281. La Coruña: Ediciós Do Castro.

Macarro, J. M. 2000. Socialismo, República y Revolución en Andalucía (19311936): 443. Universidad de Sevilla.

Montero Moreno, A. 1998.Historia de la persecución religiosa en España: 19361939., Madrid: Biblioteca de Autores Cristianos. 
Moral Roncal, A. M. 2009. La cuestión religiosa en la Segunda República española. Iglesia y carlismo. Madrid: Biblioteca Nueva.

Ordóñez Márquez, J. 1968. La apostasía de las masas y la persecución religiosa en la provincia de Huelva 1933-36, Madrid: CSIC.

Ortiz Heras, M. 1996. Violencia política en la II República y el primer franquismo. Albacete, 1936-1950: 56. Madrid: Siglo XxI.

Ostolaza, M. 2009. «La guerra escolar y la movilización de los católicos en la II República», en F. Montero García y J. Cueva Merino (eds.), Laicismo y catolicismo. El conflicto político-religioso en la Segunda República. Universidad de Alcalá de Henares: 326-341.

Payne, S. G. 2005. El colapso de la República. Madrid: Esfera de los Libros.

Rey Reguillo, F. 2009. «Anticlericalismo, movilización católica e intransigencia política en La Mancha (1931-1936)», en F. Montero García y J. Cueva Merino (eds.), Laicismo y catolicismo. El conflicto político-religioso en la Segunda República. Universidad de Alcalá de Henares.

Rey Reguillo, F. 2008. Paisanos en lucha. Exclusión política y violencia en la Segunda República española. Madrid: Biblioteca Nueva.

Verdoy, A. 1995. Los bienes de los jesuitas. Disolución e incautación de la Compañía de Jesús durante la Segunda República, Madrid: Trotta.

Villa García, R. 2011. «La CNT contra la República: la insurrección revolucionaria de diciembre de 1933». Historia y Política 25: 177-205. 